\title{
DISSERTAÇÕES DE MESTRADO
}


CANUTO, José Roberto

Origem dos diamictitos e de rochas associadas do Subgrupo Itararé, no sul do Estado do Paraná e norte do Estado de Santa Catarina. 15 de outubro. 187p. 1 vol. Orientador: Antonio Carlos Rocha Campos.

Resumo: A presente dissertação tem por objetivo discutir os resultados do projeto de estudo da fácies e provável origem dos diamictitos neopaleozóicos do Subgrupo Itarare, aflorantes no sul do Estado do Paraná e norte do Estado de Santa Catarina, e de algumas rochas sedimentares a eles associadas.

O estudo baseou-se no exame megascópico de características estruturais, texturais e nas relações estratigráficas, além da análise paleontológica dos diamictitos e de outros sedimentos, expostos em cortes das rodovias BR-116 (entre os km 174, no Paraná e 26, em Santa Catarina), BR-476 (entre os km 48 e 114) e BR-277 (entre os km 158 e 226), os dois últimos totalmente incluídos no Estado do Paraná, perfis estes informalmente designados como Campo do Tenente-Itaiópolis, Lapa-São Mateus do Sul e PalmeiraIrati, respectivamente.

O Subgrupo Itararé, na área estudada, corresponde a uma sequêencia sedimentar com espessura máxima de $760 \mathrm{~m}$, subdividida em três formações, a saber: Campo do Tenente (espessura máxima estimada: $200 \mathrm{~m})$, Mafra (310 m) e Rio do Sul $(250 \mathrm{~m})$.

Diamictitos distribuem-se de modo generalizado nas três unidades, podendo constituir a litologia predominante em algumas seções, juntamente com os arenitos, folhelhos, siltitos, varvitos e ritmitos.

Basicamente, os diamictitos subdividem-se em dois grandes grupos, isto é, os maciços ou não estratificados e os estratificados, estes de ocorrência mais comum. Pelo menos 11 tipos diferentes de diamictitos maciços e estratificados foram distinguidos e caracterizados. A partir daí, tentou-se interpretar os processos sedimentares envolvidos na sua deposição, sua fácies e provável paleoambiente, utilizando-se, para isso, as informações da literatura sobre mecanismos e modelos de sedimentação glaciogênica, cenozbica e recente, que ocorre nos domínios terrestre e marinho da glaciação. Complementarmente, foram, também, utilizadas as informações derivadas da análise palinológica e micropaleontológica de amostras dos diamictitos e outras rochas locais.

Os diamictitos maciços incluem tilitos de alojamento e tilitos basais, depositados em condições terrestres ou subaquáticas. Estratificação foi encontrada em zonas dos tilitos basais, sendo mais comum em vários tipos de diamictitos depositados através de diversos processos de fluxo gravitacional de massa (por exemplo, fluxo de detritos, fluxo shumy e correntes de turbidez). Estes também podem incluir corpos formados subaereamente, mas, principalmente, em condições subaquáticas, em parte marinhas, conforme demonstram os fósseis associados.

Diamictitos das diferentes fácies compõem pelo menos 3 associações litológicas: a) terrestre/de geleira "grounded", representada por tilitos de alojamento ou basais, repousando sobre embasamento polido, estriado ou cisalhado, ou em contato lateral com depósitos fluvioglaciais; b) plataforma interna/de geleira "grounded", que pode, também, incluir tilitos de alojamento ou tilitos basais sobre embasamento polido ou cisalhado, porém recobertos por sedimentos subaquáticos, inclusive 
marinhos; c) plataforma externa/bacial, incluindo depósitos de fluxo de detritos glaciogênicos, alguns espessos e extensos, associados a folhelhos marinhos e varvitos espessos.

Embora as associações não ocorram exclusivamente em nenhuma das formações do Subgrupo Itararé, de modo geral, pode-se dizer que a associação terrestre/de geleira grounded tende a predominar no intervalo basal do Subgrupo Itararé (Formação Campo do Tenente), que pode, também, incluir fácies de plataforma interna/de geleira grounded. A segunda associação parece ser mais comum na parte média do Subgrupo Itararé e, localmente, na sua parte superior (formações Mafra e Rio do Sul). A Formação Mafra mostra, localmente, um conjunto de fácies atribuíveis à associação de plataforma externa/bacial. Algumas feições em diamictitos e sedimentos associados da Formação Rio do Sul, sugerem recorrência da associação terrestre/de geleira grounded na parte superior do Itararé.

Com base na identificação de tilitos de alojamento ou basais, associados com substrato polido, estriado ou cisalhado, pelos menos 6 ou 7 avanços das geleiras neopaleozóicas foram discriminados em um dos perfis (BR-116). Nem todas essas fases puderam, contudo, ser reconhecidas nas outras seções estudadas.

O Subgrupo Itararé, na área, $€$, também, notável pela presença de extensos e espessos corpos de arenitos fluviais interpretados como pertencentes à Formação Mafra, mas que cortam esses sedimentos embutindo-se em rochas da Formação Campo do Tenente. O mais importante é o Arenito Lapa, um longo e sinuoso corpo descontínuo, sob a forma de canal, em contato erosivo sobre diamictitos, que se estende de SE-NO, infletindo-se, depois, para o norte, por cerca de $60 \mathrm{~km}$, e que se origina junto à margem atual da bacia, a SE, conforme indicam as medidas de paleocorrentes (estratificação cruzada, lineações de partição etc.), desaparecendo a NO de Lapa.

Além dos arenitos, varvitos típicos foram identificados em vários níveis do Subgrupo Itararé, na área. Embora, no geral, restritos ao intervalo basal da seqüência (Formação Campo do Tenente), nos perfis examinados, seções espessas dessa litologia foram, também, encontradas, intercaladas com folhelhos e siltitos marinhos e depósitos de fluxo de detritos glaciogênicos, na parte média-superior da Formação Mafra. Neste caso, a gênese desses ritmitos dependeria da afluência de grandes volumes de água de degelo até a bacia de deposição.

Quanto à paleogeografia, a orientação paralela das feições de abrasão do embasamento (estrias), das paleocorrentes dos sedimentos associados, dos eixos e dos corpos lineares de arenito fluvial, ou fluvioglacial, além das dobras e lineações de arrasto, ligadas aos movimentos de massa que afetaram os diamictitos, indicam que estes foram depositados diretamente por gelo, ou resultaram da redeposição de sedimentos glaciogênicos, seja em ambiente terrestre ou subaquático, em parte marinho, em geral, paralelamente ao paleodeclive, a partir de fonte permanentemente situada ao sudeste da região pesquisada. As isópacas do intervalo basal do Subgrupo Itararé configuram sulcos alongados que se estendem da margem ao interior da bacia, também orientados paralelamente às feições direcionais acima, e que poderiam corresponder a vales modificados pela abrasão glacial.

De modo geral, interpreta-se a sedimentação do intervalo inferior do Subgrupo Itararé como, predominantemente, continental, terrestre e subaquática. A deposição dos pacotes médio e superior já teria ocorrido, ao que tudo indica, em condições, no geral, subaquáticas, provavelmente, em grande parte, marinhas, porém incluindo a recorrência das fácies terrestres da glaciação. A frequêencia de evidências de movimentos de massa e de seções contendo fósseis marinhos, na área de Rio Negro-Mafra, configura a presença de um corpo d'água marinho na área, também sugerido pela deposição das isópacas do intervalo médio do Subgrupo Itararé. 
Abstract: The present dissertation aims to discuss the results of a project of study of the facies and probable origin of the Late Paleozoic diamictites from the Itarare Subgroup, cropping out in southern Paraná and northern Santa Catarina States and of some of the associated sediments.

The study was based on the megascopic examination of structural, textural features and of the stratigraphic relationships, besides the paleontological analysis of the diamictites, and of other sediments exposed in road cuts along BR-116 (between $\mathrm{km} \mathrm{174,} \mathrm{in} \mathrm{Paraná} \mathrm{State} \mathrm{and} \mathrm{26,} \mathrm{in} \mathrm{Santa} \mathrm{Catarina} \mathrm{State),} \mathrm{BR-}$ 476 (between km 48 and 114) and BR-277 (between km 158 and 226), both in Paraná State, also informally designated as Campo do Tenente-Itaiópolis, Lapa-São Mateus do Sul and Palmeira-Irati sections, respectively.

The Itarare Subgroup in the area corresponds to a sequence of up to $760 \mathrm{~m}$, subdivided into the three formations, namely: Campo do Tenente (200 m), Mafra (310 m) and Rio do Sul (250 m).

Diamictites are widespread in the three formations, where they may constitute the main component together with sandstones, shales, siltstones, varvites and rhythmites.

Basically, the diamictites make up two groups, the massive or non-stratified and the stratified, the latter of more common occurrence. At least 11 different types of massive and stratified diamictites could be distinguished and characterized. On the basis of this, an attempt was made to interpret the sedimentary processes involved in deposition of the diamictites, their facies and probable paleoenvironment, in the light of published information mechanisms and models of glaciogenic sedimentation terrestrial and marine realms, of the Cenozoic and recent glaciations. Information derived from palynological and micropaleontogical analyses of samples of diamictites and other rocks have also been complementarely used.

Massive diamictites include lodgement and basal tillites formed under terrestrial or subaquatic conditions. Stratification may appear in parts of the basal tillites but is more common feature of the several types of diamictites deposited by different mass gravity flow processes (e.g., debris flow "slurry" flow, turbidity currents). These may also include bodies formed subaerially, but are mainly subaquatic in part marine, as demonstrated by the associated fossils.

Diamictites of the different facies compose at least three lithological associations, namely: a) terrestrial/grounded glacier, represented by lodgement tillites resting on polished, striated or sheared basement, or in lateral contact with fluvioglacial deposits; b) intemal shelf/grounder glacier, which may also include lodgement or basal tillites overlying polished, finely striated and sheared basement, but recovered by subaquatic sediments, including marine ones; c) external shelf/basinal represented by glaciogenic mass gravity flow sediments, some thick and extensive, associated with marine shales and thick varvites.

Though the associations do not occur exclusively in any of the three formations of the Itarare, in general terms, the terrestrial/grounded glacier type seems to predominate in the basal interval of the Itarare Subgroup (Campo do Tenente Formation), which may also include internal shelf/grounded glacier facies. The second association seems to be more common in the middle part of the Itarare Subgroup and locally in its upper section (Mafra and Rio do Sul Formation). The Mafra Formation also exhibits locally a set of facies assigned to external shelf/basinal association. Some features of the diamictites and associated sediments of the Rio do Sul Formation suggest recurrence of the terrestrial/grounded glacier association in the upper part of the Itararé Subgroup.

On the basis of the identification of lodgement or basal tillites overlying polished, striated or sheared basement, at least 6-7 glacier advances have been recognized along one profile (BR-116). Not all of these phase however could be recognized along the other sections studied.

The Itarare Subgroup in the area is also notable by the occurrence of extensive and thick, 
fluvial or glaciofluvial sandstone bodies, belonging to the Mafra Formation, but cutting down being included within sediments of the Campo do Tenente Formation. The most important of these is the Lapa sandstone, a long sinuous and discontinuous channel fill, in erosional contact on diamictites, trending initially from SE$\mathrm{NW}$, later inflecting towards $\mathrm{N}$, along at least $60 \mathrm{~km}$, originating close to the present basin margin as indicated by paleocurrent measurements, disappearing in the area to the NW of Lapa.

Besides the sandstones, varvites were identified at several levels within the Itarare Subgroup. Through, in general restrict to the basal interval (Campo do Tenente Formation), in the sections examined, thick sections of this rock have been found intercalated with marine shales and siltstones and glaciogenic flows, in the middle upper part of the Mafra Formation. In this case, the genesis of this sediment would depend on large amount of melt water flowing into the depositional basin.

Paleogeographically, the parallel disposition of the striate, paleocurrents, axes of the glaciofluvial linear sandstone bodies, of the folds and drag-lineations due to mass gravity flow affecting the diamictites, all point out to their deposition, directly by the ice or as result of redeposition of glaciogenic sediments, either in terrestrial or in subaquatic, in part marine environment, according to the paleoslope and from a permanent source towards $\mathrm{S}$ and $\mathrm{SE}$. Isopachs of the lower interval of the Itarare Sbgroup show elongated sulci extending from the margin towards the basin interior, also trending parallel with the above directional features. These may correspond to valleys cut in the basement and modified by glacial erosion.

In general terms the sedimentation of the lower interval of the Itarare Subgroup is interpreted as having occurred under predominant continental conditions, both terrestrial and subaquatic.

Deposition of the middle and upper sections on the other based is interpreted as mostly subaquatic,probably marine, but including also recurrence of the terrestrial conditions of the glaciation. Abundant evidences of mass gravity flow of diamictites and associated sediments and intercalation of several marine sections in the Rio Negro-Mafra area, as well as the isopach map are suggestive of the presence of a sizeable marine water body covering this part of the Paraná Basin, during sedimentation of the middle section of the Itararé.

MARCIANO, Vitória Régia Péres da Rocha Oliveiros Contribuição ao estudo da mineralogia e geoquímica de pegmatitos da região de Governador Valadares, Minas Gerais. 13 de setembro. 198p. 1 vol. Orientador: Celso de Barros Gomes.

Resumo: Os corpos pegmatíticos das lavras do Olho de Gato, Ferreirinha, Boi e Faria encontram-se localizados na Província Pegmatítica Oriental, distando $30 \mathrm{~km}$ a noroeste, da cidade de Governador Valadares, Minas Gerais; encaixados em biotita-xistos.

Fez-se estudo mais detalhado nos dois primeiros corpos, nos quais a coleta de amostra foi realizada segundo perfis, que permitem a visualização do zoneamento interno, como também a compreensão da evolução interna e a distribuição dos elementos alcalinos, alcalinos terrosos e outros, nos minerais das diferentes zonas.

Os objetivos principais deste trabalho foram: (1) a caracterização morfológica, mineralógica e geoquímica de alguns pegmatitos; (2) definição do posicionamento geológico e estratigráfico desses corpos; (3) descoberta de evidências da evolução interna capazes de auxiliar o estudo petrogenético deles.

A metodologia empregada para alcançar os objetivos já referidos foram: microscopia ótica, difração de raios-X, espectrografia por absorção de infravermelhos, microssonda eletrônica e datação de 
minerais através do método $\mathrm{Rb} / \mathrm{Sr}$.

Os corpos estudados possuem mineralogia bastante simples, apresentando-se zoneados (na provável seqüência de formação): zona marginal com uma característica assembléia mineral: albita + quartzo + biotita + muscovita + turmalina (exceto na lavra do Ferreirinha que não possui turmalinas); zona mural com albita + microclina pertitizada + quartzo + berilo; zona intermediária com grandes cristais de quartzo e microclina pertitizada; núcleo de quartzo e corpos de substituição com formas irregulares e mineralogia variada. Além dos minerais acima citados ocorrem óxidos, sulfetos, fosfatos e outros silicatos.

Os feldspatos, berilos, micas e columbo-tantalitas foram analisados quantitativamente através de diferentes métodos, tendo sido obtidos os dados referentes à malha elementar para os dois últimos.

Os valores para a triclinicidade dos feldspatos potássicos, bem como os polítipos das micas (muscovitas e muscovitas litiníferas, $2 \mathrm{M}_{1}$ ou associação deste polítipo em $1 \mathrm{M}$ e $2 \mathrm{M}_{2}$, biotitas $1 \mathrm{M}$ e lepidolitas $2 \mathrm{M}_{2}$ ) foram obtidos e lançados nos perfis.

Através das análises por espectrografia por absorção de infravermelhos, constatou-se a presença, na estrutura da maioria dos minerais constituintes destes corpos de $\mathrm{CH}_{4}, \mathrm{CO}_{2}, \mathrm{OH}$ e $\mathrm{H}_{2} \mathrm{O}$.

Este último método citado demonstrou a substituição do silício tetraédrico pelo boro, nas micas, feldspatos, quartzo, berilos e granadas em corpos onde não há ocorrência de turmalina, ou quando o aparecimento dela é bastante restrito.

O enriquecimento em elementos alcalinos nos feldspatos e micas é crescente da zona marginal em direção ao núcleo, enquanto para os elementos alcalinos-terrosos se dá em sentido contrário.

A cristalização dos corpos do Olho de Gato e Ferreirinha parecem ter seguido o modelo proposto por Uebel, sendo apresentada e discutida no texto.

As duas datações pelo método $\mathrm{Rb} / \mathrm{Sr}$ são concordantes e representam o evento termotectônico Brasiliano, sendo interpretadas como a idade de cristalização dos pegmatitos.

Quanto à origem, a geoquímica dos minerais, principalmente feldspatos e micas, como também a não ocorrência de corpos graníticos próximos aos pegmatitos estudados, tende a ser interpretada como anatética.

Abstract: The Olho de Gato, Ferreirinha, Boi and Faria pegmatites belong to the huge Brazilian Eastern Pegmatite Province and are located $30 \mathrm{~km}$ northwestward from Governador Valadares in the Minas Gerais State. The country rocks of these pegmatites are biotite bearing schists.

A more detailed study was carried out on the two first bodies according to the better quarrying facilities found there. In them the sampling of the major minerals was undertaken according to the internal zonation.

Three have been the main purposes of this word: (1) the gathering of morphological, mineralogical and geochemical evidences in the pegmatites themselves; (2) the understanding of the geological setting of these bodies; and (3) a final attempt to understand the petrogenesis and the internal evolution of these pegmatites.

To arrive at these purposes the pegmatites have been meticulously sampled according to its internal zonation. The zonation and sampling points of the major minerals (alkali feldspars and micas), have been recorded and charts prepared during the field work.

The polarization microscope, the X-ray diffraction and X-ray fluorescence, the microprobe, the infrared absorption etc. Have been used in the laboratory studies of the sampled material. Rb- Sr ages of two samples have been also obtained. 
The internal zonation, reflecting the morphology of the pegmatite body itself, and the major minerals occurring within the zones are: (1) border zone with albite, quartz, biotite, and book muscovite; (2) wall zone with albite, perthite and quartz mainly with graphic intergrowths; (3) intermediate zone with giant perthites and quartz and (4) quartz core. Scattered in the pegmatites mainly in the hanging wall, occur small replacement bodies the major mineralogy of which is cleavelandite and brownish mica. Some of the minor minerals which have been found are: schorlit in the border zone; beryl and Ta poor columbites in the wall and intermediate zones; apatite and herderite in the replacement bodies and late hydrothermal minerals and sulfides.

The crystallization sequence of the minerals occurring in the pegmatites is presented and discussed in the text.

The chemical composition of alkali feldspars, beryls, micas and columbo-tantalites and the cell parameters of some of them have been determined according to its petrogenetic meaning.

The triclinicity values in the $\mathrm{K}, \mathrm{Na}$-feldspars the mica polytypes as well have been determined. Among the mica polytypes the most frequent of them is the $2 \mathrm{M}_{1}$, is muscovites and $\mathrm{Li}$ bearing muscovites. The lepidolites are of $2 \mathrm{M}_{2}$, type. The polytype $1 \mathrm{M}$ has been found associated with the biotites. Sometimes the polytype $2 \mathrm{M}_{1}$ occurs associated with the $1 \mathrm{M}$ and/or $2 \mathrm{M}_{2}$ ones.

Through the infrared absorption of beryls, micas, feldspars, quartz and others it became evident the presence of $\mathrm{CH}_{4}, \mathrm{CO}_{2}, \mathrm{OH}$ and $\mathrm{H}_{2} \mathrm{O}$ within the structure of these minerals. In the tourmaline lacking pegmatites, as it appears in the Ferreirinha one, some of the infrared absorption/diagrams of the same minerals show a very sharp absorption which has been identified as meaning the presence of $B$ in tetrahedral sites.

The geochemistry of feldspars and micas seems to represent an anatectic origin for the pegmatitic material, which have been emplaced in biotite bearing schists seemingly without parent granites in the neighborhood.

The distribution pattern of the alkali elements in feldspars and micas and that of the $\mathrm{Ca}$ in the same minerals seems to represent a crystallization trend according to the Uebel's model.

The two $\mathrm{Rb} / \mathrm{Sr}$ ages are concordant and represent the Brazilian thermotectonic event. They are interpreted to represent the crystallization age of the pegmatites.

\section{MELLO E SOUZA, Silvia Helena de}

Fácies sedimentares das formações Estrada Nova e Corumbataí no Estado de São Paulo. 14 novembro. 142p. 1 vol. Orientador: Kenitiro Suguio.

Resumo: A Formação Estrada Nova, constituída dos Membros Serra Alta (inferior) e Teresina (superior), aflora nas porções sudoeste e centro-sul do Estado de São Paulo. A Formação Corumbataí, presente no flanco nordeste do Estado, é considerada indivisa.

O estudo de fácies sedimentares propiciou, além da subdivisão litoestratigráfica acima citada, a reconstrução paleoambiental e o reconhecimento de compartimentação da Bacia do Paraná pelo Rio Tietê durante o Permiano Superior.

Foram distinguidas nas formações Estrada Nova e Corumbatá, oito fácies e cinco subfácies, baseadas principalmente na associação de litologias e estruturas sedimentares primárias. As características das fácies sedimentares e as suas associações, levaram à identificação de depósitos de alto-mar (offshore), 
de zona de transição entre alto-mar (offshore) e face de praia (shoreface), de planície de maré, de barra de maré e lagunar.

Na Formação Estrada Nova há um predomínio de sedimentos de alto-mar e de planície de maré, enquanto que a sedimentação da Formagão Corumbatar teria ocorrido principalmente em zona de transição entre alto-mar e a face de praia.

A deposição dessas formações teria ocorrido em mar epicontinental, em condições de estabilidade tectônica e aridez climática. A regressão do mar permiano é evidenciada pela gradação de sedimentos de alto-mar a planície de maré e de laguna costeira, pelo incremento de areias de cores avermelhadas e pela ocorrência de restos vegetais, tais como, Lycopodiopsis derbyi e Pecopteris spp.

Abstract: The Estrada Nova Formation, composed of the Serra Alta (lower) and Teresina (upper) members, crops out in the southwest and central-southern regions of the São Paulo State. The Corumbataf Formation, northeast São Paulo, is considered a lateral equivalent but is indivisible.

On the basis of the study of sedimentary facies, lithostratigraphic subdivision, paleoenvironmental reconstruction and the recognition of the compartmentalization of the Paraná Basin during the Late Permian, have been possible.

Eight facies and five subfacies were distinguished in the Estrada Nova and Corumbatar formations, based mainly on lithological association and primary sedimentary structures. The properties of these features permits the identification of deposits of offshore, transitional offshore-shoreface, tidal flat, tidal bar and lagoon environments.

In the Estrada Nova Formation, the offshore and tidal flat deposits are predominant, whereas in the Corumbatai Formation sedimentation occurred mainly in the transitional offshore and shoreface environment.

These formations were deposited in an epicontinental sea under tectonically stable condition and an arid climate. Regression of the Permian sea is evidenced by the upward passage of offshore sediments to tidal flat and lagoon sediments, by the increase of red sands and by the presence of plant fossils, such as, Lycopodiopsis derbyi and Pecopteris spp. in the middle and upper parts of these formations.

RODRIGUES, Eleno de Paula

O Complexo Alcalino de Anitápolis - um estudo petrologico. 17 de maio. $173 \mathrm{p} . \quad 1$ vol. Orientador: Vicente Antonio Vitorio Girardi.

Resumo: O Complexo Alcalino de Anitápolis situa-se nas partes mais rebaixadas de uma depressão morfologica de forma circular e área global de $15 \mathrm{~km}^{2}$. Compreende um corpo arredondado, com área de ordem de $6 \mathrm{~km}^{2}$, circundado por rochas graníticas pertencentes ao Embasamento Cristalino (Suíte Pedras Grandes).

As rochas alcalinas do Complexo ocorrem preferencialmente em quatro zonas aproximadamente concêntricas, assim distribuídas (da borda para o centro): Zona álcali sienítica (álcalisienitos, mela-álcali-sienitos, lusitanitos); Zona nefelina sienítica (nefelina sienitos, malignitos, shonkinitos); Zona ijolítica (urtitos, ijolitos, melteigitos) e Zona ultramáfica (biotita piroxenitos, biotititos, piroxenitos, magnetita dunitos). Todas essas rochas acham-se irregularmente cortadas por veios, de espessura milimétrica a métrica, de carbonatito geralmente sövítico. A mineralização apatítica associa-se 
principalmente às rochas máficas e ultramáficas.

A intensa atividade metassomática que afetou as rochas do complexo foi responsável pela fenitização dos granitos encaixantes, pela cristalização generalizada de piroxênio (egirina a egirina-augita) e nefelina, e pelo amplo desenvolvimento de estruturas de substituição mineral.

Este trabalho apresenta os resultados dos estudos mineralogicos, petrográficos e químicos efetuados em amostras de rocha. Propõe também uma hipótese para a evolução petrogenética do Complexo Alcalino, envolvendo intrusão de rochas ultramáficas, metassomatismo e mobilização reomórfica de magma alcalino e, finalmente, venulação carbonatítica.

Abstract: The Anitápolis Alkaline Complex in Santa Catarina State, Southern Brazil, is emplaced in granitic rocks of the Embasamento Cristalino (Suíte Pedras Grandes) and is made up of a rounded body with a mapped area of about $6 \mathrm{~km}^{2}$. It is located in the inferior most depressed region of a circular structure covering $15 \mathrm{~km}^{2}$.

Four roughly concentric zones of alkaline rocks were mapped, in the following order, from border to the center; 1) alkali syenite; 2) nepheline syenite; 3) ijolite; 4) ultramafite (mainly biotite pyroxenite).

All the lithologies are cut by irregular veins-millimeters to several meters thick - of sövitic carbonatite. Some tinguaite dykes have been found in the granitic aureole. Apatite mineralization is concentrated in the mafic to ultramafic portions of the body.

Fenites, implanted in the granite contacts, generalized alkali pyroxenization and nephelinization, together with ample development of replacement structures, attest to an intensive metasomatic activity in the complex.

Mineralogical, petrographic and chemical data are presented for the range of rock types. They suggest a petrogenetic evolution, starting with the intrusion of ultramafic rocks, metasomatism and rheomorphic mobilization of alkaline magma and ending by carbonatitic venulation.

\section{SANTORO, Edgard}

Geologia da Folha Cabreúva. 27 de fevereiro. 114p. 1 vol. Orientador: Georg Robert Sadowski.

Resumo: O mapeamento geológico na escala 1:50.000 da Folha Cabreúva revelou uma distribuição regional de tipos litológicos condicionada pela zona de falhamento de Jundiuvira. Ao norte desta falha ocorrem rochas metamórficas de grau forte, possivelmente do Complexo Amparo (Proterozóico Inferior), e um pacote de rochas quartzíticas que sustenta a Serra do Japi e parte da Serra do Guaxatuba, de posição estratigráfica incerta. Ao sul desta estrutura ocorrem metamorfitos de grau fraco a médio do Grupo São Roque (Proterozóico Superior).

No Complexo Amparo foi reconhecida a presença de um grupo de dobras representável em macroescala, cuja correlação estrutural com as demais unidades é pouco segura. Nas rochas quartzíticas da Serra do Japi foram reconhecidas duas fases de deformação, sendo que a última delas origina macroestruturas.

No Grupo São Roque ocorrem três fases de dobramento, sendo que a segunda e terceira fases são responsáveis pela estruturação do Grupo na escala do mapa, constituindo as macroestruturas de 
interferência $\mathrm{F}_{2}-\mathrm{F}_{3}$ nas regiões de Pirapora do Bom Jesus, do Córrego do Braiaiá e do Córrego do Itavoca.

Os granitóides intrusivos às rochas do Grupo São Roque constituem o Batólito de São Roque e o Stock de Sorocaba. O primeiro corpo é sintectônico à segunda fase de dobramento que afetou as rochas deste Grupo, enquanto que o segundo corpo ocupa posição sin- a tarditectônica em relação a esta fase de deformação. Ocorrem ainda na Folha, intrusões de corpos graníticos pós-tectônicos representados pela exposição de parte do Batólito de Itu e do Stock de Cachoeira, e rochas subvulcânicas associadas a este magmatismo.

Zonas de falhamento transcorrente cortam rochas proterozoicas e granitóides presentes na Folha, destacando-se dentre elas a zona de falhamento de Jundiuvira, que se mostra com uma largura bastante expressiva.

A cobertura paleozóica da Bacia do Paraná encontra-se representada por uma pequena faixa de ocorrência da Formação Itararé, e as coberturas cenozóicas se restringem às calhas das principais drenagens.

Abstract: The geological mapping of Cabreava Quadrangle Area at the scale of 1:50,000 showed a regional distribution of lithological types determined by the Jundiuvira Fault Zone. North of this fault, highgrade metamorphic rocks are found, probably from Amparo Complex (Lower Proterozoic), as well as quartzitic rocks, which sustain both Japi and part of Guaxatuba mountains, of uncertain stratigraphic position. South of the above mentioned fault zone occur low to medium-grade metamorphic rocks, from São Roque Group (Upper Proterozoic).

A group of folds, which can be established on the geological map, but of doubtful structural association with other regional structures was recognized in the Amparo Complex. In the quartzitic rocks of the Japi Mountain two phases of folding generation were identified, the latter being responsible for macroscopic folding.

Three phases of folding generation occur in the São Roque Group, the second and third ones being responsible for the structure outline of the Group at the map scale. Both still form the $F_{2}-F_{3}$ largescale interference structures in the areas of Pirapora do Bom Jesus, and Braiaía and Itavoca streams.

Granitoid intrusions into São Roque Group give rise to the São Roque Batholith and Sorocaba Stock. The first one is syntectonic to the second phase of folding, while the second one is syn to tarditectonic. Intrusions of posttectonic granitic bodies, represented by exposures of parts of both Itu Batholith and Cachoeira Stock, as well as subvolcanic rocks, associated to this plutonism, are also present in the studied area.

Proterozoic and granitoid rocks are cut wrench faults. The Jundiuvira Fault Zone, that shows a very impressive breadth, is the most remarkable one.

The Paleozoic capping of the Paraná Basin is represented by a short zone of exposure of Itarare Formation, and the Cenozoic capping is restricted to the main drainage channels.

STEIN, Dirceu Pagotto

M-06

Esboço da evolução geológica pré-cambriana da Folha Pilar do Sul, SP-SF.23-Y-C-IV-4. 16 de abril. 148p. 1 vol. Orientador: Yociteru Hasui.

Resumo: A área estudada compreende a Folha Pilar do Sul (SF.23-Y-C-IV-4), localizada a oeste da 
cidade de São Paulo, da qual dista aproximadamente 140 quilômetros. É delimitada pelos paralelos $23^{\circ} 45^{\prime}$ e $24^{\circ} 00^{\prime}$ de latitude sul e pelos meridianos $47^{\circ} 30^{\prime}$ e $47^{\circ} 45^{\prime}$ de longitude oeste, perfazendo cerca de 675 $\mathrm{km}^{2}$.

Os estudos foram realizados em nível compatível com a escala de 1:50,000 e objetivaram esboģar a evolução geológica pré-cambriana da área, concatenando-se processos litogenéticos, deformacionais, metamórficos e magmáticos que foram caracterizados.

A reconstituição estratigráfica pode ser entendida através da ordenação de distintas associações de rochas. Desta forma, em direção ao topo, tem-se: metamorfitos do Complexo Pré-Açungui, metamorfitos do Grupo São Roque, rochas granitóides e cataclásticas, e coberturas sedimentares fanerozbicas e diques de diabásio.

O Complexo Pré-Açungui é admitido Pré-Proterozoico Superior, tendo sido correlacionado a porções basais das supracrustais que se apresentam no sul paulista e leste paranaense. Tais porções são consideradas basais do Grupo Açungui lato sensu e denominadas também Formação, Grupo ou Complexo Setuva. Os metamorfitos da área estudada, provisoriamente designados Complexo Pré-Açungui, constituem-se na continuidade dessas seqüências identificadas no Vale do Ribeira.

O Complexo Pré-Açungui foi subdividido em três grandes unidades, que são, sumariamente, filitos, xistos e xistos feldspatizados localmente migmatizados. As mesmas mostram passagens amplas e transicionais entre si e podem ser englobadas em duas grandes seqüências. A seqüência oriental tem caráter mais basal, englobando xistos, feldspatizados ou não, e migmatitos localizados. Nestas rochas, se interpõem núcleos de paragnaisses e principalmente de ortognaisses, além de constantes e delgados corpos e boudins de anfibolitos. A seqüência ocidental é francamente filítica, com intercalações de quartzitos e de corpos de metabasitos espessos aparecendo em nível bem definido. Várias subseqüências se individualizam, merecendo destaque a subseqüência metavulcano-sedimentar, caracterizada pela presença de metabasitos e possíveis metatufos associados.

Esse conjunto de rochas sofreu três fases principais de deformação, sendo a primeira delas caracterizada principalmente pela forte transposição impostas às seqüências. As duas fases subseqüentes são relacionadas a intensos processos de crenulação. Processos lineagênicos, responsáveis por grandes falhas transcorrentes e insignificantes falhas normais ligadas à Reativação Wealdeniana, completam o quadro deformacional.

O metamorfismo se apresenta em duas fases principais, a primeira progressiva e regional, alcançando o grau médio a forte. A segunda evidencia-se através de porfiroblastos, sendo caracterizada como de grau fraco a médio e possivelmente também de caráter regional. Os processos subseqüentes correspondem a metamorfismo de contato e dinâmico, que se associam a intrusões granitóides e falhamentos, respectivamente, e a uma fase de metamorfismo retrógrado.

Além do magmatismo pré-tectônico, caracterizado por metabasitos, metaultrabasitos e ortognaisses, duas fases principais de natureza ácida são registradas. Correspondem aos granitoides da Suíte Piedade e da Suíte Tapiraí, do final do Proteroz6ico, e da Suíte Pilar do Sul, posterior às suítes anteriores, do Eopaleozóico. Raros diques de diabásio mesozóicos resgistram a última manifestação magmática.

Os metamorfitos do Grupo São Roque afloram em área extremamente restrita, não permitindo uma caracterização representativa deste grupo. Tais fatos levaram a considerá-lo à luz da bibliografia, o que implica atribui-lo ao Proterozbico Superior. Correlações entre o Grupo São Roque e o Complexo Pré- Açungui não são consideradas factíveis no momento.

As coberturas fanerozoicas são representadas pelo Grupo Tubarão (Formação Itararé), 
cujos sedimentos denotam condições continentais e ação de geleiras, e pelos sedimentos aluviais cenozóicos presentes em terraços subatuais e planícies atuais.

Abstract: The studied area corresponds to the Pilar do Sul Quadrangle (SF.23-Y-C-IV-4) at 1:50,000 scale. It is located $140 \mathrm{~km}$ to the west of São Paulo City, between the coordinates $23^{\circ} 45^{\prime}, 24^{\circ} 00^{\prime}$ South, and $47^{\circ} 30^{\prime}, 47^{\circ} 45^{\prime}$ West, and comprises about 675 square kilometers. The main target of this work was to outline the Precambrian geologic evolution of the area by means of the general data on lithogenetic deformational, metamorphic and magmatic processes.

Stratigraphy was established through the ordering of different rocks associations. Therefore, older rock are metamorphic rocks of the Pre-Açungui Complex, followed by metamorphic rocks of granitoid and cataclastic rocks, dolerite dikes and a Phanerozoic sedimentary cover.

The Pre-Açungui Complex is believed to be older than the Upper Proterozoic. It is correlated to lower parts of supracrustals which are present in southern São Paulo State and eastern Paraná State.

The Pre-Açungui Complex was divided in the following three broad lithologic units: phyllites, schists and feldspathic schists locally migmatized. These units show wide transitional boundaries and may be grouped into two sequences. The lower eastern sequence comprises schists, feldspathized schists and locally migmatites, with nuclei of paragneiss and mainly orthogneiss, and also frequent and thin bodies and boudins of amphibolites. The upper western sequence is mainly constituted by phyllites, with intercalated quartzites and thick stratigraphically well defined bodies of metabasites. Many subsequences may be individualized; the most outstanding of them is the metavolcano-sedimentary sequence which is characterized by metabasites associated with rocks that are probably metatuffs.

Three main deformational phases affected the metamorphic rocks. The first one is characterized by intense transposition which affects the rock units. The other two younger phases are related to intense crenulation processes.

These main phases are followed by a lineagenic process which was responsible for large transcurrent displacements, and by small normal faults believed to be related to the so-called Wealden Reactivation.

Two main metamorphic stages were defined. The early one is regional and progressive from medium to high degree. The second one is indicated by the presence of porphyroblasts and is characterized by a low to medium degree; it has probably a regional character. Thermal and cataclastic metamorphism associated respectively to granitoid intrusions and faulting, followed by diaphthoresis are the final processes.

Besides the pretectonic magmatism characterized by metabasites, metaultrabasites and orthogneiss, two magmatic phases of acid nature were recognized which correspond to Upper Proterozoic granitoid rocks of the Piedade and Tapiraí Suites, and the younger Eopaleozoic Pilar do Sul Suite. The last magmatic event is represented by Mesozoic dolerite dikes.

A better characterization of the São Roque Group in the area was not possible due to the restrict area of its outcropping. Previous data indicate its age to be Upper Proterozoic. Up to this moment there is not definitive data that allow to correlate it to Pré-Açungui Complex.

Phanerozoic covers are represented by tills of the Tubarão Group (Itararé Formation) and alluvial Cenozoic sediments in terraces and flood plains. 
VLACH, Silvio Roberto Farias

Geologia, petrologia e geocronologia das regiōes meridional e oriental do Complexo Morungaba, SP. 09 de julho. 253p. 1 vol. Orientador: Horstpeter Herbeto Gustavo José Ulbrich.

Resumo: O Complexo Intrusivo de Morungaba, com área de $330 \mathrm{~km}^{2}$, aflora ao sudeste do Estado de São Paulo, apresentando forma irregular, alongada segundo SW-NE. É composto principalmente por rochas granitóides com biotita; dioritos são subordinados.

O mapeamento faciologico detalhado (escala 1:50.00) das partes meridional e oriental do complexo $\left(200 \mathrm{~km}^{2}\right)$, permitiu o reconhecimento de 31 fácies granitóides (incluindo duas de rochas dioríticas), com características estruturais-petrográficas proprias. A maioria das fácies (mapeadas como associação de fácies) E agrupada em três suítes magmáticas, denominadas Rósea, Cinzenta e Porfirtica.

A Sufte Rósea é formada por quartzo-monzonitos, granitos $3 \mathrm{~b}$ e granitos $3 \mathrm{a}$, predominantemente equigranulares de granulação média a grossa e por granitóides-pórfiros, os quais afloram como corpos alongados a subcirculares, acompanhando as estruturas regionais. No diagrama QFA-P, as rochas definem, em parte, tendência calco-alcalina granodiorítica-monzonítica. Nas rochas mais máficas (M' entre 5 e 15$)$ encontra-se a associação máfica biotita + titanita + magnetita \pm alanita \pm ilmenita; as rochas mais félsicas $\left(M^{\prime} \cong 5\right)$ apresentam biotita \pm alanita \pm muscovita + magnetita \pm ilmenita. $\mathrm{Na}$ parte sul do complexo, as fácies distribuem-se segundo um padrão concêntrico de zonalidade. As características geologicas e estruturais-texturais indicam que as rochas mais félsicas, e mais jovens, têm histórias de cristalização mais simples e que se colocam sob regimes mais permissivos, termicamente menos rigorosos, que as rochas mais máficas e mais antigas. Os granitóides-pórfiros são manifestações derradeiras, colocadas subsuperficialmente, como corpos menores e diques. A maioria das fácies invadiu como corpos discretos. Dados geocronologicos $\mathrm{Rb} / \mathrm{Sr}$ para grupos de fácies associadas definem intervalos amplos de colocação e/ou cristalização (690 Ma. para rochas mais máficas; $490 \mathrm{Ma}$. rochas mais félsicas), os quais são exagerados e devem-se, provavelmente, à influência de diversos processos petrogenéticos (e.g., não-homogeneidade isotópica da área-fonte, cristalização fracionada). Uma isócrona conjunta, para a maioria das fácies desta suíte, indica idade de $580 \mathrm{Ma}$. Acredita-se que a maioria das fácies se posicionou entre $590 \mathrm{Ma}$. e $560 \mathrm{Ma}$. As razões iniciais obtidas $(0,707-0,706)$ são compatíveis com derivação a partir de fonte na crosta inferior, possivelmente pós-transamazônica.

A Sufte Cinzenta agrupa fácies equigranulares de granulação fina a média, com tipos hololeucocráticos $\left(M^{\prime} \cong 5\right.$; granitos $3 \mathrm{~b}$ com biotita + muscovita \pm granada \pm ilmenita $)$ e leucocráticos $\left(M^{\prime}\right.$ entre 5 e 10; granitos $3 \mathrm{~b}$ e subordinadamente granodioritos, ambos com biotita + titanita + magnetita \pm alanita \pm ilmenita ou com associação máfica similar aos tipos hololeucocráticos). As rochas são mais antigas que a maioria dos granitóides da Suíte Rósea. As fácies hololeucocráticas apresentam idade $\mathrm{Rb} / \mathrm{Sr}$ de 590 Ma. e razão inicial 0,709, compatível com fonte metassedimentar isotopicamente pouco evoluída. As fácies leucocráticas são de origem híbrida, produto de assimilação de rochas dioríticas (a maioria do embasamento) por magmas que originam principalmente as fácies hololeucocráticas; apresentam, caracteristicamente, enclaves e glomérulos máficos (com biotita + plagioclásio + titanita + magnetita + apatita \pm ilmenita, de origem restítica).

A Suite Porfiritica, mapeada parcialmente, compreende quartzo, monzonitos, granitos $3 \mathrm{~b}$ e granitos 3a, predominantemente porfiríticos, de granulação média a grossa. Apresentam M' entre 5 e 15 e contêm biotita \pm hornblenda + titanita + magnetita \pm alanita \pm ilmenita. Afloram na parte N/NE do complexo como corpos alongados, colocados sob regimes forçados, subconcordantes com os padrões 
estruturais regionais SW-NE. As rochas desta suíte são anteriores aos granitóides equigranulares, apresentando idade isocrônica $(\mathrm{Rb} / \mathrm{Sr})$ de $610 \mathrm{Ma}$. e razão inicial de 0,707 , sugerindo que os magmas são originados por fusão de materiais da crosta inferior.

Os dioritos compreendem em parte rochas híbridas, derivadas por interação de rochas dioríticas mais máficas do embasamento com magmas granitóides das Suítes Rósea e Cinzenta. Também incluem prováveis corpos magmáticos discretos, colocados sincronicamente aos granitóides.

Os granitóides das Sứtes Rósea e Porfirítica são correlacionáveis aos granitóides da série magnetítica e, em parte, aos granitoides de tipo I Caledoniano, enquanto que os da Suíte Cinzenta correspondem em parte aos granitóides da série ilmenítica (e granitóides tipo S) e, em parte, aos da série magnetítica. O Complexo Intrusivo de Morungaba, colocado em grande parte durante fases de soerguimento regional, representa os eventos tardi- e pós-orogênicos do Ciclo Brasiliano.

Abstract: The Morungaba Granitoid Complex, covering about $330 \mathrm{~km}^{2}$, crops out as an elongate irregular massif trending SW-NE, in the southeast part of the São Paulo State, southeast Brazil. Major constituents are biotite granitoids with subordinate diorites.

Over thirty facies types, each with distinctive structural-petrographic features, were recognized during detailed mapping of part of the massif (about $200 \mathrm{~km}^{2}$ ), and mapped as groups of facies.

The Pink Granitoid Suite is made up mostly of equigranular quartz monzonites and 3b-3a granites, with some granite porphyries. Modes depict, in part, a calc-alkaline tendency in the modal Q-AF-P triangle. The more mafic facies (M' about 5-15) contain biotite + sphene + magnetite \pm allanite \pm ilmenite, while the more felsic types $\left(M^{\prime} \cong 5\right)$ show biotite \pm allanite \pm muscovite \pm magnetite \pm ilmenite. Granitoids are distributed in a roughly concentric pattern in the southern part of massif. Geological and petrographic characteristics indicate that more felsic (and later) facies - in contrast to mafic types - had simpler crystallization histories and were emplaced under thermally less rigorous, and structurally more permissive, regimes. Granite porphyries are late rocks, emplaced as shallow (subvolcanic?) dikes and small bodies. Most facies types penetrated as discrete magmatic volumes. Geochronological $\mathbf{R b} / \mathrm{Sr}$ data for several groups of associated facies suggest a protracted emplacement interval, between $690 \mathrm{Ma}$ for the more mafic groups and $490 \mathrm{Ma}$ for the more felsic varieties. This interval seems unacceptably long, however, and probably reflects the existence of "fictitious isochrons" conditioned by several special petrogenetic processes (e.g., lack of isotopic homogeneity in the source region, influence of magmatic differentiation). A joint isochron of the Pink Suite indicates an age of $580 \mathrm{Ma}$. It is suggested that the ages of various facies lie between 560 and $590 \mathrm{Ma}$. The initial ${ }^{87} \mathrm{Sr} /{ }^{86} \mathrm{Sr}$ ratios of about $0.707-0.706$ are compatible with a lower crust, possibly post-Transamazonic source.

The Gray Suite, also equigranular, comprises hololeucocratic (3b granites with biotite + muscovite \pm garnet \pm ilmenite; $M^{\prime} \cong 5$ ) and leucocratic types ( $3 \mathrm{~b}$ granites and subordinate granodiorites with biotite + sphene + magnetite + allanite + ilmenite or the same mafic minerals of the hololeucocratic varieties; M' about 5-15). These rocks are older than most facies of the Pink Suite. Hololeucocratic types show a $\mathrm{Rb} / \mathrm{Sr}$ isochronic age of $590 \mathrm{Ma}$ and an initial $87 \mathrm{Sr} / 86 \mathrm{Sr}$ ratio of 0.709 , compatible with a metasedimentary source. The leucocratic facies are mostly hybrid rocks, a mixture of evolved granite magmas (which crystallized mainly as hololeucocratic types) and older basement diorites. These rocks contain characteristic enclaves and mafic clots (restitic, with biotite + plagioclase + sphene + magnetite + apatite + ilmenite).

The Porphyritic Granitoid Suite, only partly mapped, comprises mostly porphyritic quartz monzonites and $3 \mathrm{~b}-3 \mathrm{a}$ granites, with biotite \pm hornblende + sphene + magnetite \pm allanite \pm ilmenite, which 
crop out as forcefully emplaced elongate bodies, trending SW-NE, subconcordant with the basement structures. These varieties are older than the equigranular rocks from the two other suites. $\mathrm{A} \mathrm{Rb} / \mathrm{Sr}$ isochron furnishes an age of $610 \mathrm{Ma}$ and an initial ratio of 0.707 , also compatible with a derivation from a lower crustal source.

Diorites are partly hybrid rocks, a result of interaction between more mafic basement diorites and evolved granite magmas, but probably also include small magmatic bodies, emplaced contemporaneously with other granitoids.

The granitoids of the Pink and Porphyritic Suites are comparable to magnetite-granites and, in part, to I-type Caledonian granites, while those of the Gray Suite present characteristics of both Magnetite-, Ilmenite- (and S-) granite types. The Morungaba Complex was emplaced mostly during regional uplift, and represents late- to posttectonic magmatic stages of the Brasiliano Orogeny.

\section{6}

\section{ATENCIO, Daniel}

Sulfatos secundários: relação com rochas preexistentes e síntese. 23 de julho. $210 \mathrm{p}$. 1 vol. Orientador: Raphael Hypolito.

Resumo: Este trabalho compreende o estudo de sulfatos secundários, tipos litológicos associados e soluções intempéricas da Formação Itaquaquecetuba (Bacia de São Paulo), além de experiências de intemperismo simulado e síntese de minerais do grupo da copiapita.

Em rochas da Formação Itaquaquecetuba, ocorrem como cimento os sulfetos de ferro - pirita e marcassita. A exposição destes minerais a ambiente oxidante acarreta a formação de soluções ácidas que instabilizam feldspatos, micas e outros materiais associados. A partir das soluções, precipitam sulfatos de ferro, alumínio, cálcio, magnésio, potássio e sódio. A paragênese de alteração é semelhante à verificada em fontes termais (alteração argilosa avançada).

Estudos mineralógicos e químicos permitiram identificar os sulfatos melanterita, rozenita, coquimbita, metavoltina, alunogênio, epsomita e gipsita, além de minerais dos grupos da halotriquita, da copiapita e da alunita. Várias transformações mineralógicas ocorreram após coleta, formando-se, inclusive, materiais não registrados nos afloramentos de Itaquaquecetuba, como: roemerita, paracoquimbita e um sulfato amorfo de ferro. Sulfatos de origem singenética ou diagenética, como barita e gipsita, também foram registrados.

A coloração dos sulfatos inclui tonalidades de verde, amarelo, branco, laranja, rosa e castanho, que mudam de intensidade devido, principalmente, a variações nos teores de água estrutural ou de umidade e a associação com fases amorfas. $O$ hábito dos minerais e agregados reflete cristalização rápida, observando-se crostas, agregados sacaróides ou fibrosos e estalactites.

A seqüência de formação aproximada para os sulfatos de Itaquaquecetuba obedece a seguinte ordem: sulfatos "normais" hidratados de ferro (II); sulfatos "normais" e hidroxisulfatos de ferro 
(II), ferro (III) e outros cátions; hidroxisulfatos hidratados de ferro (III) e outros cátions. Após esta etapa, duas linguagens divergentes foram verificadas, uma delas com a formação de sulfatos "normais" hidratados de ferro (III), e outra com a origem de hidroxisulfatos de ferro (III) e eventualmente com outros cátions. A etapa final de alteração gera goethita.

Vários tipos de águas naturais foram identificados nos portos de areia de Itaquaquecetuba. As amostras estudadas, com valores de $\mathrm{pH}$ entre 2,30 e 2,90, representam apenas os estágios finais do processo de alteração. Experiências de intemperismo simulado em amostras de concreção de sulfeto, em arenito, revelaram a existência de soluções com valores de $\mathrm{pH}$ de $\mathbf{0 , 4 0}$. Estas experiências permitiram, também, o cálculo dos valores de mobilidade relativa dos elementos, os quais refletiram, de maneira aproximada, a ordem de decomposição dos minerais da rocha. Sob as condições dos experimentos, similares às verificadas em Itaquaquecetuba, os sulfetos são menos alteráveis que os plagioclásios e mais instáveis em relação ao microclínio.

Experiências de síntese em temperatura e pressão ambientais resultaram na obtenção, pela primeira vez, de vários compostos análogos e minerais do grupo da copiapita, incluindo-se alumino copiapita, magnesiocopiapita, zincocopiapita, ferricopiapita, "niquelcopiapita", "manganocopiapita" e "cobaltocopiapita", estes três últimos não conhecidos em ocorrência natural. No caso de tentativa de síntese de copiapita, calciocopiapita e cuprocopiapita, cristalizaram-se misturas de minerais do grupo da copiapita com composição química próxima a esperada e outras espécies.

Abstract: This dissertation comprises a study of secondary sulfates and associated rocks and weathering solutions from the Itaquaquecetuba Formation (São Paulo Basin). Results of simulated weathering experiments and synthesis of minerals of the copiapite group are also reported.

In the Itaquaquecetuba Formation the iron sulfides pyrite and marcasite occur as cement. The exposure of these minerals to oxidizing conditions causes the formation of acid solutions that attack feldspars, micas and other materials. From these solutions iron, aluminium, calcium, magnesium, potassium and sodium sulfates precipitate. The alteration paragenesis is similar to that verified in thermal springs (advanced argillic alteration).

Mineralogical and chemical studies permitted the identification of the sulfates melanterite, rozenite, coquimbite, metavoltine, alunogen, epsomite and gypsum, as well as minerals of the halotrichite, copiapite and alunite groups. Several mineralogical transformations take place following sample collection, including the formation of materials not reported in Itaquaquecetuba outcrops, such as roemerite, paracoquimbite, and as amorphous iron sulfate. Sulfates of syngenetic or diagenetic origin, such as barite and gypsum, were also reported.

The colour of the sulfates includes hues of green, yellow, white, orange, pink and brown that change in intensity due mainly to variations in the content of structural or adsorbed water and to the association with amorphous phases. The habit of the minerals and aggregates - crusts, saccharoidal or fibrous aggregates and stalactites - reflects rapid crystallization.

The approximate sequence of formation of the Itaquaquetuba sulfates is as follows: hydrated "normal" sulfates of iron (II); "normal" and hydroxysulfates of iron (II), iron (III) and other cations; hydrated hydroxysulfates of iron (III) and other cations. After this stage, two divergent lineages are apparent, one with the formation of hydrated "normal" sulfates of iron (III) and the other with the formation of hydroxysulfates of iron (III) and eventually other cations. The final step of alteration produces goethite.

Several kinds of natural waters reported in the sand pits of Itaquaquecetuba. The studied samples with $\mathrm{pH}$ between 2.30 and 2.90 , represent only the final stages of the alteration process. Simulated 
weathering experiments on a sample of sulfide aggregate in sandstone revealed the existence of solutions with $\mathrm{pH}$ of $\mathbf{0 . 4 0}$. These experiments also allow the calculation of the relative mobility of elements, which approximately reflects the sequence of decomposition of the minerals in the rock. Under experimental conditions similar to those verified at Itaquaquecetuba the sulfides are less alterable than the plagioclases yet more unstable than microcline.

Synthesis experiments at room temperature and pressure produced, for the first time, several, compounds analogous to minerals of the copiapite group, including aluminocopiapite, magnesiocopiapite, zincocopiapite, ferricopiapite, "nickelcopiapite", "manganocopiapite", and "cobaltocopiapite", these last three not known is natural occurrences. Attempts to synthesize copiapite, calciocopiapite and cuprocopiapite resulted in the crystallization of mixtures of minerals of the copiapite group having chemical composition near the expected values together with other species.

BORTOLOTTO, Olavo José

M-09

Petrologia dos mármores de Caçapava do Sub RS. 18 de dezembro. 103p. 1 vol. Orientador: Marcos Aurélio Farias de Oliveira.

Resumo: A região de Caçapava do Sul, no Estado do Rio Grande do Sul, compreende, principalmente, a Quadrícula de mesmo nome e abrange cerca de $11.000 \mathrm{~km}^{2}$.

A referida região é caracterizada pela ocorrência de um batólito granítico (Granito Caçapava) com afloramento de $25 \times 10 \mathrm{~km}$, orientado no sentido N-S, e sobre o qual assenta-se a cidade supracitada.

O Granito Caçapava é circundado por um cinturão de metamorfitos pertencentes à Formação Vacacaí, Grupo Porogos (Pré-Cambriano Superior) (RIBEIRO et al., 1966). Dentre os metamorfitos situa-se um corpo de rochas carbonatadas de aspecto lenticular, com contatos nítidos, interpenetrado por apofises graníticas e com um afloramento de aproximadamente $17 \mathrm{~km}^{2}$.

Foram estudadas amostras deste corpo de rochas por meio de microscopia, microssonda eletrônica, difratometria e espectrometria de raios $\mathrm{X}$ e análise química por via úmida, com o objetivo de identificar e caracterizar os minerais carbonáticos e silicáticos.

Por meio de técnicas de coloração, foi possível a distinção de dolomita (Do), calcita (Cc) e calcita ferrífera (Ccf).

As análises modal e química indicaram predominância de carbonatos sobre silicatos, estando estes ultimos relacionados mais às bandas da rocha.

Os minerais silicáticos detectados foram: talco, tremolita, diopsídio, forsterita, clorita e flogopita. Em menores quantidades aparecem titanita, apatita e quartzo, sendo comum, também, a serpentina oriunda de alteração da forsterita.

Lançados em mapa, os minerais índices mostraram a existência de um zoneamento metamórfico com rochas pertencentes à Fácies Piroxênio Hornfels, próximo ao contato, e de rochas da Fácies Albita-Epídoto Hornfels, em porções mais distantes, evidenciando, assim, metamorfismo térmico.

Com base em diagramas $\mathrm{T}-\mathrm{X}_{\mathrm{CO}}$ para o sistema $\mathrm{CaO}-\mathrm{MgO}-\mathrm{SiO}_{2}-\mathrm{CO}_{2}-\mathrm{H}_{2} \mathrm{O}$, foi analisado o metamorfismo destas rochas e estimadas as temperaturas máximas de ordem de $560^{\circ} \mathrm{C}$, compatíveis com as temperaturas magmáticas do Granito Caçapava.

A conclusão final advinda com os estudos ora realizados, sobre essas rochas carbonáticas, 
aponta no sentido de se tratarem de mármores dolomíticos impuros de contato, gerados durante o Ciclo Brasiliano (680 a $500 \mathrm{Ma}$.).

Abstract: The Caçapava do Sul region, Rio Grande do Sul State, comprises mainly the area of the same name and encompasses about $11,000 \mathrm{~km}^{2}$.

This region is characterized by the occurrence of a granitic batholith (Caçapava Granite), that has an outcrop of about 25 by $10 \mathrm{~km}$, oriented North-South, on which is located the homonymous city, Caçapava do Sul.

The Caçapava Granite is surrounded by a belt of metamorphites belonging to the Vacacaí Formation, Porongos Group (Upper Precambrian) (RIBEIRO et al., 1966). Among the metamorphites is located a carbonatic rock body, lens shaped, whit clear contacts, interpenetrated by granitic apophysis and with an outcrop of about $17 \mathrm{~km}^{2}$.

Samples of this rock body were studied by microscopic, electronic microprobe, diffractometry and spectrometry of $\mathrm{X}$ ray and chemical analysis aiming at identifying and characterizing the carbonatic and silicatic minerals.

Through staining techniques it was possible to distinguish dolomite (Do), calcite (Cc) and ferriferous calcite (Ccf).

The modal and chemical analysis showed that the carbonatic minerals were more abundant than the silicatic ones being these last ones restricted to of rock bands.

The detected silicatic minerals were the following: talc, tremolite, diopside, forsterite, chlorite and phlogopite. In smaller amounts titanite, apatite and quartz also occur. Serpentine resulting from alterations in the olivine is also very common.

Plotted on map, the index minerals showed the existence of a metamorphic zonation in rocks belonging to a Pyroxene-Hornfels Facies, near the contact, and rocks of the Albite-Epidote Hornfels Facies, placed farther away from the granitic body. Therefore, this fact emphasizes the presence of thermal metamorphism.

Based on T- $\mathrm{X}_{\mathrm{CO}}$ diagrams for the CaO-MgO-SiO $2-\mathrm{CO}_{2}-\mathrm{H}_{2} \mathrm{O}$ system, the metamorphism of these rocks was analysed and its temperatures were estimated about $560^{\circ} \mathrm{C}$, which conforms to the Caçapava Granite magmatic temperatures.

The final conclusions with these studies, about the carbonatic rocks, indicate that they are contact impure dolomitic marbles, generated during the Brazilian Cycle (680-500 Ma).

\section{CARNEIRO, Mauricio Antonio}

Contibuição à geologia da região de São José dos Quatro Marcos, MT. 16 de maio. 156p. 1 vol. Orientador: Horstpeter Herbeto Gustavo José Ulbrich.

Resumo: O mapeamento geológico (escala 1:100.000) réalizado na região de São José dos Quatro Marcos, sudoeste de Mato Grosso, revelou marcada variedade litológica. Predominam, como rochas consideradas do embasamento, gnaisses cinzentos tonalíticos, com lentes e bandas interestratificadas de anfibolitos ("primeira geração") e escassas ocorrências de granulitos. Gnaisses róseos oftalmíticos, de composição granítica, são considerados granitóides porfiríticos deformados, enquanto que alguns afloramentos de rochas calco-silicáticas bandadas são representantes de seqüências supracrustais 
deformadas e metamorfizadas. Estas rochas são invadidas por várias fácies de granitóides róseos e cinzas, tanto maciços como orientados. Petrograficamente, são tonalitos, granodioritos e granitos $3 \mathrm{a}$ e $3 \mathrm{~b}$, que aparecem no campo como blocos isolados e geralmente alternantes (i.e. maciços "não circunscritos"), colo cados numa seqüência que se inicia com tonalitos precoces e finaliza com granitos tardios. Estes granitóides mostram enclaves de gnaisses cinzentos e de anfibolitos ("segunda geração"). Um corpo anfibolítico de dimensões maiores, aflorando a W da área mapeada, é considerado também de "segunda geração". Para leste, aparecem alguns afloramentos isolados de riolitos porfiríticos, com matriz esferulítica.

Todas as unidades mencionadas são descritas petrograficamente, apresentando-se adicionalmente várias dezenas de modas de gnaisses cinzento, anfibolitos, rochas calco-silicáticas e granitoides. As observações geológicas são lançadas num "mapa de domínios petrográficos", que mostra a distribuição, no campo, dos tipos petrográficos dominantes.

Determinações radiométricas pelo método $\mathrm{Rb} / \mathrm{Sr}$ mostram idades isocrônicas de $1.971 \pm 70$ Ma. (quatro amostras de um único afloramento) para gnaisses cinzentos, e $1.472 \pm 19 \mathrm{Ma}$. (seis amostras) para granitóides róseos; as razões iniciais são 0,7017 e 0,7037 respectivamente, indicando evolução a partir de materiais primitivos. Idades $\mathrm{K} / \mathrm{Ar}$, em gnaisses cinzentos e anfibolitos são da ordem de $1.500 \mathrm{Ma}$.

A área mapeada é parte integrante de uma "faixa deformada" de maior extensão, com os gnaisses cinzentos formando o embasamento para rochas supracrustais (calco-silicáticas), com posterior invasão de granitóides "não circunscritos", que marca, por volta de $1.500 \mathrm{Ma}$., um evento térmico-tectônico relacionado à "reativação" Parguazense (Ciclo San Ignacio).

As correlações com unidades formais definidas em áreas vizinhas, são dificultadas pela falta de mapeamento de maior detalhe. Considera-se prematura a atribuição das rochas do embasamento (gnaisses cinzentos etc.) ao Complexo Xingu, originalmente definido na Amazônia Central. As rochas calco-silicáticas, remanescentes de seqüências supracrustais mais espessas, são possíveis equivalentes de pacotes semelhantes já mapeados em áreas vizinhas (e.g. Seqüência Vulcano-Sedimentar Quatro Meninas). As rochas granitóides foram geradas provavelmente por anatexia da crosta primitiva, e pertencem a "Suite Intrusiva Guapé" como redefinida no presente trabalho. Os anfibolitos de corpos maiores, "segunda geração", são os equivalentes da Suíte Intrusiva Rio Alegre, enquanto que os riólitos são prováveis cronocorrelatos do Grupo Rio Branco.

Abstract: Geologic mapping (1:100,000) in São José dos Quatro Marcos, southwestern Mato Grosso State, showed a remarkable lithological variety. Predominant, among basement rocks, are grey tonalitic gneisses, with interlayered "first generation" amphibolite lenses and bands and rare granulite occurrences. Associated pink granitic gneisses, with ophtalmitic structures, are probably deformed early porphyritic granites. Sparse outcrops of banded calc-silicate rocks are remnants of supracrustal sequences. These rocks are invaded by several facies of pink and grey granitoid types, both massive and slightly oriented, which are petrographically tonalites, granodiorites and $3 \mathrm{a}-3 \mathrm{~b}$ granites. These granitoids are observed in the field as isolated blocks of very variable petrography, intruded in a time sequence starting with tonalites, and ending with late pink granitoids. Granitoids show enclaves of both grey gneisses and "second generation" amphibolites; a larger amphibolite body, observed in the western part of the mapped area, is also considered part of this "second generation" sequence. To the E, scattered outcrops of porphyritic rhyolites, with a spherulitic matrix, were observed.

All the mentioned units were described petrographically; several tens of modes of grey gneisses, amphibolites, calc-silicate rocks and granitoids are also presented. Geologic observations are shown in a "map of petrographic domains", which identifies, as objectively as possible, the distribution 
pattern of the rock types.

Two $\mathrm{Rb} / \mathrm{Sr}$ isochrons are presented, one for grey gneisses (four points of a single outcrop), yielding an age of $1,971 \pm 70 \mathrm{Ma}$, the other for the granitoid intrusives (six points), with an age of $1,472 \pm 19$ Ma. Small initial ratios ( 0.7017 for grey gneisses, 0.7037 for granitoids), suggest that these rocks originated from metamorphism and/or partial fusion of primitive material, $\mathrm{K} / \mathrm{Ar}$ ages cluster around 1,500 Ma both for grey gneisses and several samples of amphibolites.

The mapped area is part of a "deformed belt" of greater dimension; grey gneisses are considered basement rocks, upon which supracrustal sequences (calc-silicate rocks) were deposited, later invaded by network of granitoids. The last occurrences, dated at about 1,500 Ma, marked a significant thermal and tectonic event, probably associated with the Parguazense "reactivation" (San Ignacio Cycle).

Correlation with other units, formally defined in nearby areas, is difficult, on account of the lack of detailed mapping of regional extent. There is no supporting data for defining the grey gneisses as "Xingu Complex" rocks, since this last unit was originally defined in Central Amazônia. Calc-silicate rocks are probably equivalent of thicker supracrustal sequences mapped in the vicinity (e.g. the Quatro Meninas volcano-sedimentary sequence). The granitoid rocks, probably generated by anatexis of primitive crust, is correlated with the "Guape Intrusive Suite", as here redefined. Amphibolites of the second generation (specially the larger bodies) are probably equivalent to the "Rio Alegre Intrusive Suite" of basic rocks, while rhyolites are tentatively compared with the volcanic rocks of the Rio Branco Group.

\section{CORREIA, Ciro Teixeira}

Geologia da Folha de Cássia, MG, e petrologia de seus anfibolitos. 15 de dezembro. 123p. 1 vol. Orientador Vicente Antonio Vitorio Girardi.

Resumo: A geologia da região da Folha Topográfica de Cássia-MG, na escala 1:50.000, revela a presença de três unidades metamórficas. Rochas gnáissicas granodioríticas e tonalíticas ortoderivadas e gnaisses migmatíticos representam o embasamento do Grupo Araxá. Xistos, quartzitos, gnaisses e subsidiariamente, metatexitos, metaultramafitos, anfibolitos, protominérios de Mn e rochas cataclásticas constituem o Grupo Araxá. Filitos e quartzitos pertencem ao Grupo Canastra.

Estruturas superpostas indicam no mínimo três fases deformacionais para as rochas de embasamento e duas para as rochas do Grupo Araxá e Canastra.

Análises radiométricas mostram idades transamazônicas ou mais antigas para as rochas do embasamento. Idades brasilianas, Rb-Sr, de $760 \mathrm{Ma}$., referem-se aos metatexitos do Araxá, enquanto que o padrão K-Ar obtido data entre 580 e $644 \mathrm{Ma}$. o fechamento dos sistemas minerais para a difusão do Ar, ou para difusão isotópica da rocha total, para o sistema Rb-Sr.

$O$ estudo das paragêneses minerais revela condições metamórficas de fácies anfibolitos para as rochas do Grupo Araxá e de seu embasamento. No Grupo Canastra o metamorfismo atingiu o fácies xisto verde. Nota-se que o metamorfismo progride em direção as porções N-NE da área.

Dados geotermométricos indicam temperaturas de $650^{\circ} \mathrm{C}$ a pouco superiores a $725^{\circ} \mathrm{C}$ para o evento térmico culminante durante o Ciclo Brasiliano. Indiretamente são estimadas condições mínimas de pressão equivalentes a 6,5 kbar atuantes durante este evento.

Dados químicos de elementos maiores e menores, associados com parâmetros de Niggli, mostram origem ortometamórficas para os anfibolitos do Grupo Araxá em Cássia. Indicam ainda que estas 
rochas se originaram a partir de magmas basálticos, provavelmente não co-genéticos. Quando comparados com basaltos formados em ambientes modernos, possuem similaridades com os formados em margens de placas.

Abstract: The Cássia region (SW Minas Gerais State) has been mapped at a scale of 1:50,000. Geologically, the area consists of three metamorphic sequences. Granodioritic and tonalitic gneisses of igneous parentage and migmatic gneisses form the basement of the Araxa Group, which is mainly made up of schists, quartzites, and gneisses with subordinate metatexites, metaultramafites, amphibolites, manganese protores and cataclasites. The third unit is the Canastra Group, comprising phyllites and quartzites.

The basement rocks were affected by at least three deformational phases, whereas the Araxa and Canastra Groups show the effect of at least two deformational events.

Radiometric data on the basement rocks point to minimum ages corresponding to the Transamazonic Cycle (1,800 Ma). Some of the data indicate the effects of the Brasiliano Cycle. For example, metatexites of the Araxá Group yield an age of $760 \mathrm{Ma}$ ( $\mathrm{Rb}-\mathrm{Sr}$ isochron), and the closure of the systems for Ar diffusion out of minerals and $\mathrm{Sr}$ diffusion within the whole rock occurred between 580 and $644 \mathrm{Ma}$.

The basement rocks and the Araxá Group belong to the amphibolite facies. The Canastra Group is, on the other hand, characterized by the greenschist facies. Metamorphic grade increases towards the north and northeast.

The temperatures obtained through geothermometry vary from $650^{\circ} \mathrm{C}$ to slightly greater than $725^{\circ} \mathrm{C}$ for the culmination of the metamorphic event of the Brasiliano Cycle. Minimum pressures are estimated at around $6.5 \mathrm{kbar}$.

Chemical data for major and trace elements and the relationships between the Niggli numbers indicate that the amphibolites of the Araxá Group in the Cássia region are of igneous parentage. They probably were derived from several non cogenetic types of basaltic magmas. When compared to basalts belonging to modern environments, they show similarities with those formed at plate margins.

DIAS NETO, Coriolano de Marins e

Contribuição à análise sismotectônica da Regiäo Sudeste do Brasil. 08 de maio. 121p. 1 vol. Orientador: Georg Robert Sadowski.

Resumo: A avaliação da atividade sísmica conhecida e a proposição de possíveis associações desta, com estruturas potencialmente favoráveis à liberação de esforços na região sudeste brasileira se constitui no principal objetivo deste trabalho.

Com um enfoque convergente são fornecidas informações a respeito da atividade sísmica intraplaca a nível global, juntamente com tentativas de interpretação sismotectônica de diversos autores, comenta-se a sismicidade do Brasil e, com detalhe, a da região objeto deste estudo.

Apesar da quantidade de dados sísmicos ser a mais significativa em termos da atividade sísmica brasileira, acredita-se que muitos eventos ocorridos na região sudeste podem ter sido perdidos por falta de registro escrito ou instrumental. Em parte esta relativa concentração de sismos pode refletir o padrão de ocupação populacional, assim como a possibilidade de registro instrumental mais eficiente, na última década, que nas outras regiões brasileiras. 
A distribuição dos eventos conhecidos parece indicar a ocorrência preferencial de atividade sísmica nas áreas afetadas pelo Ciclo Brasiliano e na margem continental correlata, onde se desenvolve a Bacia de Santos, do que na cobertura fanerozóica da Bacia do Paraná.

Com base nos modelos propostos e informações disponíveis discute-se a evolução tectônica meso-cenozoica da região de interesse, procurando-se identificar as estruturas favoráveis à liberação de esforços, com as quais os eventos sísmicos pudessem estar associados.

Considera-se a possibilidade dos sismos estarem relacionados aos produtos tafrogênicos da Reativação Wealdeniana, os quais foram fortemente condicionados pelo trend estrutural regional do final do Ciclo Brasiliano. Defende-se também a provável existência de grandes descontinuidades seccionando este trend, as quais teriam desempenhado um papel de destaque no âmbito da evolução meso-cenozóica, e que atualmente, poderiam ser responsáveis pela ocorrência de sismos em suas proximidades.

\begin{abstract}
This work is an attempt to delineate the relation between known seismicity and the geological structure of Southeast Brazil.

Informations about the global intraplate seismic activity are commented in the light of some current seismotectonic interpretations.

The distribution of known seismic events suggests that seismic activity occurs mainly within areas affected by the "Brasiliano Cycle" and along the continental margin.

Based on available models the Mesozoic-Cenozoic tectonic evolution of the studied area is discussed and an attempt is made to identify geologic structures responsible for recent seismic events.

The results of this research seem to indicate seismotectonic relationships with known structural elements of intraplate environments, such as lines of inherited weakness formerly activated during continental break-up and alignment of more recent alkaline intrusives.
\end{abstract}

DINIZ, Mírian Nóbile

Interpretação ambiental da Formação Ponta Grossa na parte central da Bacia do Paraná - um estudo de subsuperficie. 17 de abril. 148p. 1 vol. Orientador: Oscar Rösler.

Resumo: Neste trabalho, são interpretados ambientes deposicionais da Formação Ponta Grossa (Bacia do Paraná), na sub-bacia devoniana sul, com base em perfis elétricos e radioativos (raios gama), testemunhos e amostras de calha de poços perfurados pelo PAULIPETRO - Consorcio CESP/IPT, no oeste do Estado de São Paulo e nạ porção centro-oeste do Estado de Paraná.

$\mathrm{Na}$ região do Pontal do Paranapanema (SP), a sul do Alinhamento Estrutural de Guapiara, a unidade pode ser dividida em duas fácies fundamentais: a subseqüência inferior, de caráter pelítico, marinho raso, transgressivo, incluindo relativa estabilidade ou lenta elevação do nível do nível do mar, e a superior, dominantemente siltico-arenosa, de padrão regressivo, devendo corresponder a pequenos deltas do tipo dominado por marés e a depósitos associados sob condições de mesomaré, com aparente registro de canais de maré e sem a formação de ilhas-barreiras (similar ao modelo de sedimentação recente para a costa da Alemanha, Mar do Norte). Admite-se um ambiente semi-restrito de sedimentação, como o de baía, extensa, condicionado pela atuação positiva do Alinhamento de Guapiara - mais efetiva para a subseqüência superior, e com área-fonte, provavelmente, a leste-nordeste.

No Estado do Paraná, caracterizam-se, litologicamente, três intervalos estratigráficos 
informais: a subseqüência inferior, com depósitos pelíticos, de origem transgressiva, em ambiente de plataforma rasa; a média, mais sítica, com intercalações de bancos arenosos e padrão geral progradacional, no perfil de raios gama, mostrando pequenos ciclos transgressivos, e fonte principal de sedimentos a oestesudoeste; e a subseqüência superior, distinguindo-se da inferior pela maior proporção de níveis arenosos, com feições transgressivas, oscilatórias e sedimentação em águas calmas ou mais agitadas (zonas de inframaré de maior profundidade a intermaré inferior), possivelmente, com área-fonte também a nordeste.

Na faixa centro-oeste do Estado do Paraná, a subseqüência média poderia representar a parte submersa de delta assimétrico formado pela interação de suprimento de sedimentos fluviais (orientado para nordeste, região do depocentro, área de Apucarana, PR - prodelta) e de efeitos de marés, talvez, da ação de ondas, subordinadamente. Supõem-se condições interdeltaicas de macromaré, com sistemas, perpendiculares à costa, de barras arenosas, espessando-se para leste, segundo o provável fluxo das marés. Para esses depósitos arenosos - marcantes na parte superior da subseqüência -, a ampla distribuição geográfica, associada à espessura pequena ou média (até pouco menos de $40 \mathrm{~m}$ ), são sugestivas de declividade suave de uma plataforma extensa e tectonicamente mais estável para a borda oeste da sub-bacia, e de aporte rápido de sedimentos.

A erosão de praticamente toda a subseqüência superior, em algumas seções do Estado do Paraná (poşos 1-CS-2-PR, 1-PT-1-PR, 1-RS-1-PR), durante a fase pré-carbonifera, bem como, a expressiva espessura ocasional da subseqüência inferior (poços 1-CA-3-PR, 1-RS-1-PR), evidenciam uma subcompartimentação da bacia devoniana, com significativo controle tectônico sobre a sedimentação da Formação Ponta Grossa, em certas áreas.

Em direção ao centro-leste/nordeste do Estado do Paraná, fora da área estudada, pode ocorrer gradiente acentuado por falhamentos locais, como indicam o rápido espessamento de partes da unidade (poços 1-CA-3-PR, 1-CA-1-PR) e o registro de litologias atípicas, por exemplo, arcóseos líticos, às vezes, mais grosseiros, no poço 1-R-1- PR, da PETROBRÁs.

Abstract: In this dissertation, depositional environments of the Ponta Grossa Formation in the southern Devonian subbasin of the Paraná Basin have been interpreted on the basis of well logs, cores and cuttings from wells drilled by PAULIPETRO (CESP/IPT Consortium) in western São Paulo and central and western Paraná State, Brazil).

In the region of Pontal do Paranapanema (SP), just south of the Guapiara Structural Alignment, this formation may be divided into two basic facies: a lower shallow marine, transgressive pelitic sub-sequence, evidencing local conditions of relative stability and slow rise in sea level; and an upper predominantly sandy silty, regressive sub-sequence, probably corresponding to small, tide-dominated deltas and associated mesotidal deposits, including tidal channels, but lacking typical barrier islands (similar to present-day sedimentation in German Bay, North Sea). It is thought that sedimentation took place within a geographically restricted environment, such as a large bay, and was controlled by the positive action of the Guapiara Alignment, especially with regard to the upper sub-sequence. The probable source of the sediments was located to the east-northeast.

For sections in Paraná State, three informal lithological units have been characterized: the lowest sub-sequence consists of transgressive pelites deposited on a shallow platform (shelf- mud); the middle sub-sequence, which is siltier with sandy intercalations, exhibits a progradational pattern interrupted by lesser transgressive cycles (as interpreted from the gamma-ray log), and was supplied by sediments from the west-southwest; and the uppermost sub-sequence, distinguishable from the basal one by its greater number of sandy intercalations, shows an oscillating pattern of transgressive sedimentation and changes in 
environmental energy which represents deeper subtidal to lower intertidal zones of a marine shelf sequence, with sediments possibly also derived from the northeast.

Towards central-western Paraná area, between the rivers Ivaí and Piquiri, the middle subsequence apparently represents the submerged part of an asymmetrical delta formed by the interaction of fluvial sediment supply and tidal effects and possibly, wave action, to a lesser degree. Associated with this there was an interdeltaic macrotidal system of linear sand ridges perpendicular to the paleocoast and thickening eastward in the direction of the probable tidal currents. Prodelta deposits apparently occur to the northeast, near Apucarana (PR), in the region of the depocenter. The great areal distribution and moderate to narrow thickness of the sandy deposits characteristic of the upper-part of the middle subsequence, suggest a gentle gradient over a broad platform tectonically more stable towards the western border of the sub-basin, and a rapid influx of sediment.

Pre-Carboniferous erosion of practically all the upper sub-sequence in some Paraná sections, as well as the occasional thickening of the lowest sub-sequence, comprises evidence of compartmentalization (by faulted blocks) of the basin and local significant tectonic control of the sedimentation.

Towards east and northeast in Paraná State, outside the study area, atypical lithologies (e.g. lithic arkoses) and rapid thickening of parts of the section suggest a steeper gradient (local slopes) controlled by faults.

JANASI, Valdecir de Assis

M-14

Geologia e petrologia do Maciço Monzodiorítico-monzonítico de Piracaia, SP. 27 de agosto. 281p. 1 vol. Orientador: Horstpeter Herbeto Gustavo José Ulbrich.

Resumo: $\quad$ m maciço de Piracaia aflora na parte $\mathrm{N}$ do Estado de São Paulo, ocupando área de $32 \mathrm{~km}^{2}$. E composto por uma suíte de rochas em boa parte gnaissificadas e metamorfizadas, dominada por monzodioritos e monzonitos, mas com variações desde dioritos até álcali-quartzo sienitos e álcali granitos. A tendência composicional assim definida é semelhante a da série granitóide "alcalina" (LAMEYRE \& BOWDEN, 1982).

As rochas do maciço invadem a região de contato entre ortognaisses do Complexo Socorro e rochas supracrustais migmatizadas do Complexo Metamórfico Piracaia. São invadidas restritamente por veios granitóides; as relações de contato com corpos maiores de granitóides anatéticos vizinhos não são claras. A geração da foliação presente nas rochas do maciço é atribuída à fase de deformação $\mathrm{F}_{\mathrm{n}+\boldsymbol{Z}}$ dobras mega e mesoscópicas da fase $\mathrm{F}_{\mathrm{n}+3}$ afetam essa foliação.

Rochas monzodioríticas e monzoníticas formam a parte central do maciço e são invadidas, nas bordas, pelos termos mais diferenciados, numa seqüência geral de colocação "máfico-félsico". A colocação dos fácies tardios se processa sob um regime de esforços.

As rochas ígneas preservadas no maciço têm como minerais principais plagioclásio, feldspato alcalino, biotita e augita. Fe-hiperstênio só aparece em alguns monzonitos, e quartzo, nas rochas mais diferenciadas. Como acessórios mais comuns, encontram-se apatita, magnetita e ilmenita.

A cristalização dos feldspatos geralmente se inicia com o plagioclásio, mesmo em termos mais diferenciados, onde ele é mais sódico. Nas rochas monzodioríticas-monzoníticas, após a coprecipitação de ambos os feldspatos, pode ser atingido um estágio de reabsorção do plagioclásio.

Os máficos principais e a sua seqüência de cristalização (biotita antes de augita, em especial 
nos monzodioritos) refletem a composição das rochas (principalmente, a riqueza em potássio), e o caráter pouco hidratado do sistema. A tendência, com a diferenciação, é de um aumento da razão $\mathrm{Fe} /(\mathrm{Fe}+\mathrm{Mg})$ em ambos os minerais, considerada compatível com a progressiva diminuição de $f\left(\mathrm{H}_{2} \mathrm{O}\right)$ e $f\left(\mathrm{O}_{2}\right)$ no sistema.

Em rochas monzodioríticas e monzoníticas, são comuns estruturas de segregação, como ocelos "sieníticos" e vênulas estictolíticas, em parte com migração posterior ao desenvolvimento de uma foliação. Os litotipos dos fácies claros tardios do maciço são petrograficamente semelhantes às vênulas maiores, e se colocam, ao menos em parte, após o início dos processos de segregação.

A geração inicial dos fácies dioríticos a monzoníticos "antigos" parece devida à cristalização fracionada, possivelmente governada pela extração de cristais em meio líquido. A gênese das estruturas posteriores de segregação (e dos fácies "tardios") é admitida como resultado de processos de extração de líquidos residuais, ao que parece favorecidos pela deformação. A hipótese de que as segregações sejam reflexo de processos anatéticos pode justificar a distribuição dos elementos traços, e não pode ser descartada, mas parece menos viável, dada a similaridade da composição dos minerais aí presentes com a dos que cristalizaram nas rochas ígneas primárias do maciço, e as temperaturas relativamente elevadas requeridas para a fusão de protolitos de composição intermediária.

As hipóteses genéticas foram testadas, de um modo semiquantitativo, por modelagens geoquímicas. A extração de fases de cristalização precoce (plagioclásio, biotita e augita) responde de modo satisfatório pelas tendências químicas principais do maciço. Nos modelos de cristalização fracionada, o plagioclásio responde por mais de $50 \%$ da fase sólida extraída, e tem sua participação aumentada nos estágios tardios de diferenciação, onde o clinopiroxênio é fracionado em proporção menor; a biotita é geralmente o mineral máfico mais importante no fracionamento.

O metamorfismo inicial no maciço é considerado "sinplutônico" e contemporâneo à geração de segregações. Provoca reequilíbrios químicos, como adaptação a temperaturas menores (porém ainda elevadas) e fugacidades de $\mathrm{H}_{2} \mathrm{O}$ maiores. A contínua diminuição de $\mathrm{T}$ e o aporte de mais água provocam uma sucessão de paragêneses de grau metamórfico mais baixo nas rochas do maciço, com a instabilização dos piroxênios e geração de hornblendas, que posteriormente dão lugar a paragêneses com biotita esverdeada e epídoto. O metamorfismo de grau mais baixo afeta as rochas de $75 \%$ do maciço, que paralelamente, são as que têm aspecto gnáissico mais marcante. A distribuição espacial das rochas afetadas pelo metamorfismo indica que o aporte de fluidos foi facilitado na zona de borda do maciço, em especial a leste.

Uma isócrona $\mathrm{Rb}-\mathrm{Sr}$ em rocha total de $582 \pm 13 \mathrm{Ma}$. foi obtida em rochas metamorfizadas dos fácies tardios do maciço, e é interpretada como a idade de rehomogeneização isotópica do sistema, que acompanha a recristalização das rochas, contemporânea à fase de deformação $\mathrm{F}_{n+2}$

Abstract: The Piracaia massif, located in the NE part of the São Paulo State, crops out over $32 \mathrm{~km}^{2}$. Rock types cover a wide compositional range (diorites to alkali-feldspar quartz syenites and related granites), similar to the "alkaline" granitoid tendency of Lameyre \& Bowden (1982), but monzodiorites and monzonites are by far predominant. Most rocks show, at least in part, tectonic foliation and metamorphic recrystallization.

The massif was emplaced in the area of contact between the Socorro orthogneisses and migmatized supracrustal units of the Piracaia Metamorphic Complex. Locally, late granitoid veins intruded the massif, but the contact and structural relations of the massif with nearby anatectic granites are unknown. Foliation within the massif is attributed to the regional $F_{n+2}$ phase of deformation. 
Monzodiorites and monzonites, which comprise the central part of part of the massif, were intruded along their borders by late differentiated facies, apparently under forceful conditions. The intrusion sequence proceeded from more mafic to more felsic rock types.

The principal primary minerals observed in preserved igneous textures are plagioclase, alkali feldspar, biotite and augite; Fe-hypersthene is found in some monzonites, and quartz in late differentiates. Main accessory minerals are apatite, magnetite and ilmenite.

Crystallization usually began with plagioclase and biotite, followed by augite and alkali feldspar, this last mineral usually observed as an interstitial phase. Resorption of plagioclase was probably important in many monzonites and monzodiorites, alkali feldspar occasionally being seen as mantles around this mineral.

The presence of augite and biotite in these rocks is a result of high $\mathrm{K}$ activity in the magmas, coupled with a relatively low $\mathrm{H}_{2} \mathrm{O}$ content. The chemical tendency, towards an increased $\mathrm{Fe} /(\mathrm{Fe}+\mathrm{Mg})$ ratio with differentiation in both minerals, is compatible with crystallization under diminishing $\mathrm{f}_{\mathrm{H}_{2}} \mathrm{O}$ and $\mathrm{f}_{\mathrm{O}_{\mathbf{2}}}$

Syenitic ocellar and stictolithic "segregation" structures, in part later than the development of a foliation, occur pervasively in many monzodiorites and monzonites. Larger felsic veins are also found, in part later than the earliest segregations.

The earliest rock types (diorites to leucomonzonites) show petrographic and chemical relations compatible with derivation by crystal fractionation, possibly controlled by crystal extraction from a predominantly liquid mush. Late rock types, such as small segregations and larger masses of felsic differentiates, may represent residual liquids extracted from largely crystalline mushes. Thus, normal differentiation processes are possibly responsible for the generation of both early (predominant) rocks as well as late, more felsic varieties. On the other hand, an hypothesis of partial melting of and already crystallized intermediate rock mass (early monzodiorites and monzonites), coupled with segregation, is at least compatible with the distribution pattern of some trace elements in the late felsic facies. Crystallization processes are nevertheless favoured, since the compositions of minerals in segregations are very similar to those found in early rock types, and the temperature requirements for melting of intermediate, relatively dry protoliths seem to be unreasonably high.

Petrogenetic hypotheses were tested using subtraction and trace-element diagrams. The separation of early-crystallizing minerals (plagioclase, biotite and augite) could reproduce differentiation paths like those shown by the Piracaia rocks. Up to $50 \%$ plagioclase would have to be fractionated in the early stages, and even more later; biotite and, to a lesser extent, augite, would have to be separated in significant amounts to account for major and trace element trends.

Initial metamorphism within the massif is considered "syn-plutonic", related to the beginning of segregation; primary felsic and mafic minerals recrystallized in response to diminishing (but still high) temperatures and an increase in $\mathrm{f}_{\mathrm{H}_{2}} \mathrm{O}$. Later metamorphism at diminishing temperatures generated hornblende (mainly from pyroxenes), and this, in turn, is replaced by lower-grade assemblages, mainly greenish biotite and epidote. Up to $75 \%$ of the massif shows both low-grade mineralogy and tectonic gneissic foliation; $\mathrm{H}_{2} \mathrm{O}$ influx, which favoured both deformation and recrystallization, was probably most significant along the marginal parts marginal parts of the massif.

A Rb-Sr whole-rock reference isochrone of $582 \pm 13 \mathrm{Ma}$ was obtained for the metamorphosed late facies. This value is interpreted as a metamorphic homogenization age, more or less contemporaneous with the $\mathbf{F}_{\mathbf{n}+2}$ regional phase of deformation. 
MARANHÄO, Maria da Saudade Araujo Santos

Contribuição ao conhecimento da malacofauna das camadas basais da Formação Corumbataí (Permiano), Estado de São Paulo. 29 de outubro. 89p. 1 vol. Orientador: Paulo Milton Barbosa Landim.

Resumo: Os principais objetivos deste trabalho são: 1) estudar o material malacofaunístico de novos jazigos da região de Rio Claro-Piracicaba (SP) e de testemunhos de sondagem de Conchas (SP), referentes à porção basal da Formação Corumbataí, termo superior do Grupo Passa Dois de idade permiana e 2) determinar sua distribuição bioestratigráfica.

Incluiu-se um exame parcial da provável correlação entre as faunas das bases das Formações Corumbatar (São Paulo) e Estrada Nova (Paraná) e considerações de ordem paleoecológica da malacofauna.

A análise taxanômica dos bivalves da porção basal da Formação Corumbataí no Estado, forneceu apreciável diversidade genérica e específica. Duas seçõos colunares, uma de superfície e outra de subsuperfície, são apresentadas, mostrando a distribuição bioestratigráfica dessa malacofauna.

Os bivalves identificados e descritos nos diversos afloramentos foram:

Angatubia cf. A.cowperesioides Mendes

Anthraconaia? mezzalirai sp. $\mathbf{n}$.

Barbosaia cf. B.angulata Mendes

Barbosaia roxoi sp. $\mathbf{n}$.

Casterella cf. C.camargoi Beurlen

Ferrazia simplicicarinata Mezzalira

Ferrazia sp.

Holdhausiella elongata Mendes

Holdhausiella sp.

Kidodia cf. K.stockleyi Cox

Mendesia piracicabensis gen. et sp. $\mathbf{n}$.

Plesiocyprinella sp.

Rioclaroa cf. R.lefevrei Mezzalira.

Com base na composição observada, sugeriu-se reunir as Zonas Leinzia froesi Mendes e Barbosaia angulata Mendes propostas por MEZZALIRA (1980) em uma única designada Zona Leinzia froesi- Barbosaia angulata.

Os quatros níveis fossiliferos reconhecidos em subsuperfície (Poço 1-IG-Conchas) com as espécies: Casterella cf. C.gratiosa, Ferrazia cardinalis Reed e Pinzonella cf. P.illusa, a julgar pela distribuição vertical em relação à base da formação, situar-se-iam na Zona III de MEZZALIRA (1980) considerada quando definida como afossilifera.

Dentre as principais conclusões, notou-se a predominância de bivalves com carenas simples e duplas, provavelmente caráter adaptativo ao ambiente que seria provavelmente circunscrito, mixohalino, de águas rasas, turvas e mal oxigenadas em certos intervalos.

Abstract: The main purpose of this dissertation is: 1) to study malacofaunistic material concerning new occurrences in the Rio Claro-Piracicaba (SP) region and concerning drilling core in Conchas (SP), referring the basal portion from Corumbataí Formation, upper section of the Passa Dois Group of Permian age and 
2) to determine its biostratigraphical distribution.

It is included a partial examination about the probable correlation between fauna belonging to Corumbataí Formation (SP) bases and Estrada Nova (Paraná) and considerations on malacofauna paleoecological order.

The taxonomic analysis of the basal portion bivalves from Corumbatar Formation in the São Paulo State, furnished remarkable specific and generic diversity. Two columnar section, one from surface and the other from subsurface are presented showing the malacofauna biostratigraphic distribution.

The bivalves identified and described in the various outcrops were:

Angutubia cf. A.cowperesioides Mendes

Anthraconaia? mezzalirai sp. n.

Barbosaia cf. B.angulata Mendes

Barbosaia raxoi sp. $\mathbf{n}$.

Casterella cf. C.camargoi Beurlen

Ferrazia simplicicarinata Mezzalira

Ferrazia sp.

Holdhausiella elongata Mendes

Holdhausiella sp.

Kidodia cf. K.stockleyi Cox

Mendesia piracicabensis gen. et sp. $\mathbf{n}$.

Plesiocyprinella sp.

Rioclaroa cf. R.lefevrei Mezzalira.

With basis in the observed composition, it was suggested to congregate the Zonas Leinzia froesi Mendes and Barbosaia angulata Mendes proposed by MEZZALIRA (1980) in one unique named: Zona Leinzia froesi - Barbosaia angulata.

The four fossiliferous levels acknowledged in the subsurface with the specimens: Casterella cf. C.gratiosa, Ferrazia cardinalis Reed and Pinzonella cf. P.illusa verifying by the vertical distribution related with the formation basis, it would be locate in Zona III from MEZZALIRA (1980) considered when defined as afossiliferous.

Among the main conclusions were observed the prevalence of bivalves with simple and two carina, probably an adaptation to the environment, which would be classified as: mixohalino, of shallow waters, darkish and with bad oxygenated in certain intervals.

MONTEIRO, Rubens Luiz

M-16 Aspectos geológicos, mineralógicos, petrológicos e geoquímicos de um corpo basáltico localizado no Municipio de Tanquinho, SP. 29 de dezembro. 158p. 1 vol. Orientador: Celso de Barros Gomes.

Resumo: Um corpo intrusivo (sill) localizado na região de Tanquinho, SP, foi pesquisado por método indireto de observação no sentido de serem fixados parâmetros que o melhor situasse enquanto forma, relaçōes estratigráficas e estruturais.

Investigações mineralogicas, petrográficas e geoquímicas foram executadas a partir de testemunhos de sondagem realizada naquele local pelo Instituto Geológico. 
Os minerais mais abundantes dessas rochas são plagioclásios, augita e material mesostático quartzo-feldspático; em menor quantidade aparecem opacos, pigeonita, apatita, material mesostático clorítico, filossilicatos verdes, carbonatos, hornblenda, biotita e titanita.

Estudos combinados envolvendo caracterização petrográfica dos diferentes tipos, quimismo dos minerais e rochas, difratometria dos plagioclásios etc., permitem algumas interpretações petrologicas de caráter amplo quanto à linha evolutiva do magma no corpo, assim como de algumas fases minerais.

As relações entre as fases co-precipitantes mais importantes (plagioclásios, augita e pigeonita) indicam que condições mais próximas de equilibrio foram atingidas nas proximidades do nível $28,5 \mathrm{~m}$, provavelmente o mais evoluído dos investigados em termos de diferenciação in situ.

São freqüentes as relações complexas reunindo mineralogia e textura, quer pelas variações ocorridas na posição atual, quer pelo mascaramento dessas mudanças, promovido pelas associações minerais formadas em profundidade e trazidas para a superfície.

As características químicas do magma mostram em algumas oportunidades caráter dúbio de filiação, entretanto, a presença das duas fases de clinopiroxênio (augita e pigeonita) coexistentes aponta para sua natureza dominantemente tolética.

Abstract: An intrusive body (sill) located in Tanquinho, SP, was studied indirectly in order to evaluate and characterize its stratigraphic form and relationships.

Mineralogical, petrographical and geochemical investigations were carried out on samples drilled by the Instituto Geologico.

The major constituents of those rocks are plagioclases, augite and quartz feldspar mesostasis; subordinate phases include opaque minerals, pigeonite, apatite, chloritic mesostasis, green phyllosilicate, carbonates, hornblende, biotite and titanite.

Petrographical characterization of various types, together with combined studies on mineral and rock chemistry, diffractometry of plagioclases etc., allow some general petrological interpretations to be made about the evolution of the magma and some of the mineral phases.

The relations among the more important coprecipitant phases (plagioclases, augite, pigeonite) reveal that equilibrium conditions were reached at $28.5 \mathrm{~m}$, probably the most evolved level in the in situ differentiation.

The mineralogy and the texture of the rocks show very complex relationships due to changes occurred at the actual position of the body or as a result of phases crystallized at depth and rose to the surface.

Chemical features point to the uncertain affiliation of the magma, although the presence of the two coexistent clinopyroxenęs phases (augite and pigeonite) clearly suggests a dominant tholeiitic character.

M-17

OSTAFIUC, Gerson Bardichia

Metodologia para o cálculo de reservas de turfeira de Jacareí e suas características físico-químicas. 30 de maio. 54p. 1 vol. Orientador: Evaristo Ribeiro Filho.

Resumo: O estudo da turfeira próxima a cidade de Jacareí, à margem esquerda do Rio Paraíba do Sul, apresentou resultado satisfatório, permitindo a delimitação de uma turfeira de forma alongada, de 
aproximadamente $6,0 \mathrm{~km}$ de comprimento por $1,2 \mathrm{~km}$ de largura média. A turfa aflora em $80 \%$ da área, possui espessura média de $3,00 \mathrm{~m}$, teor máximo ponderado de $50 \%$ de cinzas e $35 \%$ de umidade, apresenta uma reserva medida de aproximadamente 3.964 .500 toneladas, apresentando um conteúdo energético de $1.565 .000 \mathrm{Gcal}$.

A viabilidade econômica da turfeira de Jacaré, como alternativa energética, só poderá ser totalmente comprovada por meio da implantação de lavra experimental, quando se obtiver os custos reais necessários para extração da tonelada de turfa, que comparadas com os do óleo combustível revelará a exeqüibilidade econômica do empreendimento.

Abstract: The study a peat bog developed in Jacareí City, far from São Paulo City $60 \mathrm{~km}$ to the northeast, in the basin of Paraiba do Sul river, has presented good results, allowing the delimitation of a peat bog with $6.0 \mathrm{~km}$ long and $1.2 \mathrm{~km}$ wide.

This peat bog is about 370.0 hectares, contain about $10,999,000 \mathrm{~m}^{3}$ of peat resources with an average depth of about 3,0 metres and in some places more than 7.0 metres depth.

The analysis of the material provided of the peat bog for testing physical properties, have shown $35 \%$ of ashes content and $35 \%$ of moisture content, as well as $2,800 \mathrm{kcal} / \mathrm{kg}$ of average heating value.

The economic viability of Jacarei peatland resources, its' useful and application as an alternative energetic source depends on experimental mining tests, like exploitation and milling methods involving costs, equipments, and so forth.

SATO, Key

M-18

Síntese geocronologica do Estado da Bahia e evolução crustal, com base no diagrama de evolução do $S r$ e razões iniciais $S r^{87} / S^{86}$. 11 de agosto. 124 p. 1 vol. Orientador: Koji Kawashita.

Resumo: Com a aplicação de métodos convencionais (análise bibliográfica e trabalhos de laboratórios), foi possível, como uma primeira tentativa, elaborar-se uma evolução crustal e uma síntese geocronológica para o território baiano (parte nordeste do Cráton do São Francisco).

$\mathrm{Na}$ elaboração da evolução crustal, foram utilizados diagramas de evoluções do Sr. Nestes diagramas utilizam-se parâmetros como $\left({ }^{87} \mathrm{Sr} / 86 \mathrm{Sr}\right)_{\mathrm{i}}$, idade e relação ${ }^{87} \mathrm{Rb} /{ }^{86} \mathrm{Sr}$. As medidas das razões iniciais do $\mathrm{Sr}$ são extremamente críticas, isto $e$, a variação da RI do manto, desde os primórdios da formação da Terra, a 4,55 Ga., até hoje, é apenas da ordem de 0,005 (0,699 a 0,704). Para atender esta finalidade, foi efetuado um levantamento bibliográfico completo, sobre diversas técnicas de regressão linear, e uma avaliação dos modelos existentes.

A razão inicial do Sr foi utilizada como traçador radiogênico natural, nos estudos das petrogêneses das rochas, tendo sido, em alguns casos, complementados com idades modelos Sm/Nd e valores de $\mu_{1}(238 \mathrm{U} / 204 \mathrm{~Pb})$.

Quanto à síntese geocronologica, foi baseada nos trabalhos anteriores, existentes na área em estudo, integrando-os com os novos dados radiométricos. De uma forma em geral, podemos destacar uma série de importantes inferências, conforme se segue:

1. ARQUEANO INFERIOR-MÉEIO (3.000 Ma.) 
No interior da Bahia, encontram-se vários registros radiométricos, na forma de núcleos isolados e preservados, como Boa Vista, Sete Voltas, Mutuipe, Capim etc. Fica claro, que estes dados são, ainda, conhecidos para áreas muito dispersas, e não se pode, ainda, caracterizar um ciclo geotectônico/ geodinâmico bem definido, para esta etapa do tempo geológico na Bahia.

\section{ARQUEANO SUPERIOR (3.000-2.500 Ma.)}

O clímax do evento tectono-magmático do embasamento, no Cráton do São Francisco, ocorreria entre 2.650 a $2.850 \mathrm{Ma}$, em território baiano, principalmente no Complexo Granulítico Jequié.

\section{PROTEROZÓICO INFERIOR (2.500-1.800 Ma.)}

Ciclo Transamazônico (2.150-1.750) Ma.

É caracterizado, neste ciclo, por faixas móveis Salvador-Juazeiro (porção oriental do Estado) e regióes de Correntina/Guanambi (porção ocidental). A borda oriental (Complexo Jequiá e região de Itabuna-Salvador-Juazeiro) sofreu importante soerguimento, promovendo a ascensão de rochas formadas em grandes profundidades aos níveis superiores, entre 1.800 e $1.700 \mathrm{Ma}$., conforme indica a maioria dos resultados K-Ar.

\section{PROTEROZÓICO MÉDIO (1.800-1.000 Ma.)}

No início do Ciclo Espinhaço, desencadeou-se com as fases terminais do Ciclo Transamazônico (1,7 - 1,8 Ga.), como parecem indicar os processos tectono-magmáticos (metarriolitos R.dos Remédios e granitos de Lagoa Real). O clímax deste desenvolvimento é estimado em $1.300 \pm 100 \mathrm{Ma}$, pelo metamorfismo regional dos pelitos, seguido de eventos anorogênicos da ordem de $1.000 \pm 100 \mathrm{Ma}$.

\section{PROTEROZÓICO SUPERIOR (1.000-570 Ma.)}

No início do Proterozóico Superior é marcado conforme pode ser observado, pela deposição do Grupo Bambuí e de seus prováveis cronocorrelatos (Una, R.Pardo, Miaba etc.). A idade máxima, encontrada até o presente momento, apresenta-se, para a deposição do Grupo Una, com uma isócrona de $900 \mathrm{Ma}$., obtidas nas frações finais. Eventos precoces, não muito bem caracterizados no Proterozóico Superior, entre 1.000 e $700 \mathrm{Ma}$., ocorrem com certa freqüência nas regiōes limítrofes do Estado da Bahia. A fase principal de dobramentos e metamorfismo regional, do Ciclo Brasiliano, situa-se em torno de 500 a $700 \mathrm{Ma}$. A maioria dos dados K-Ar indica resfriamento final entre 450 e $600 \mathrm{Ma}$., nos Sistemas de Dobramentos Marginais e Espinhaço (aparente reativação plataformal no Brasiliano).

Com base nos diagramas de evoluções do $\mathrm{Sr}$, pode- se observar os seguintes fatos:

6. A idade modelo $\mathrm{Sm} / \mathrm{Nd} \mathrm{T}(\mathrm{CR})$ e a extrapolação da linha de evolução do $\mathrm{Sr}$, dos tonalitos de Boa Vista, aponta-nos uma das primeiras crostas primitivas, como núcleo isolado, há cerca de $3.700 \mathrm{Ma}$., preservado no Cráton do São Francisco.

7. Acreções e retrabalhamentos da crosta primitiva foram intensos no Arqueano, em todo o Complexo Jequié e no Cinturão Contendas-Mirante. Já a nordeste deste complexo, a Faixa Móvel Salvador- Juazeiro 
atuou, intensamente, no Proterozoico Inferior, com acreções e retrabalhamentos, deixando alguns núcleos arqueanos preservados, como a região de Serrinha/Capim e a oeste de Jacobina.

8. As razões iniciais das rochas granulíticas, do Complexo Jequié, coincidem com, ou situam-se acima da linha de evolução do manto. Para os que situam-nas acima da linha de evolução do manto, pode ter transcorrido um intervalo de tempo significativo, entre a formação do magma e o fechamento final do sistema, ou de uma refusão anatética de um material precursor mais antigo. As linhas de evolução do $\mathrm{Sr}$, para os casos dos afloramentos que tenham controle das idades modelos $\mathrm{Sm} / \mathrm{Nd}$, mostram que o metamorfismo, aparentemente, não mudou a química, permanecendo, relativamente constante, as razões $\mathrm{Rb} / \mathrm{Sr}$ em escala de afloramento. A razão $\mathrm{Rb} / \mathrm{Sr}$ destas rochas de fácies granulito, em geral, têm um valor médio da ordem de 1,5, em contraste aos baixos valores, da ordem de 0,04 , em outros terrenos do continente de mesma fácies metamórfica.

9. Os corpos granulíticos de Santa Izabel e corpos gnáissicos/migmatíticos, da região de Remanso e Lagoa Real, de idades arqueanas, tem o padrão evolutivo semelhante aos do Complexo Jequié.

10. Na Faixa Móvel Salvador-Juazeiro, os valores da razão ${ }^{87} \mathrm{Sr} / 86 \mathrm{Sr}$ inicial, dos corpos transamazônicos são, relativamente, mais baixas, da ordem de 0,704, comparado aos corpos arqueanos do Complexo Jequié, que têm altos valores, da ordem de 0,709. Portanto, torna-se difícil, para os materiais precursores deste cinturão, serem derivados do material do tipo Complexo Jequié. Um outro provável cinturão móvel transamazônico ocorre na região de Correntina, na porção ocidental do Estado da Bahia.

11. No início do Proterozóico Médio, constata-se um período de relativa calmaria, com alguns focos de vulcanismo isolados. A fase de intenso retrabalhamento crustal ocorreu na região do Espinhaço, nas partes média a final do Ciclo Espinhaço, entre 1.500 e $1.000 \mathrm{Ma}$.

Em síntese, a crosta cresceu através do tempo geológico, através de diferenciação química, quase que irreversível do manto superior. Durante o Arqueano e o Proterozóico Inferior, ocorreram refusões crustais e acreções de material para o continente. Já no Proterozoico Médio a Superior, toda a crosta já estava relativamente consolidada, predominando o sistema de retrabalhamento para novas formaçöes crustais.

Abstract: The crustal evolution of the ancient terrains of the Bahia State, Brazil, is attempted with the aid of $\mathrm{Sr}$ isotopic results as natural tracers. Some $\mathrm{Nd}$ and $\mathrm{Pb}$ isotopic data are also available, and support the main conclusions based on $\mathrm{Sr}$ evolution diagrams.

The regional geochronological pattern is as follows:

1. Several ancient nuclei, with apparent ages older than $3,000 \mathrm{Ma}$, are scattered within most of the younger units.

2. A major event in Late Archean times (around 2,700 Ma), affecting the Jequié high-grade complex, and the granite-greenstone terrain around Brumado.

3. Development of two Transamazonian mobile belts $(1,800-2,150 \mathrm{Ma})$, one in the eastern area (Salvador- 
Juazeiro Belt), and the other in the western part (Correntina-Guanambi area).

4. Development of the Espinhaço Folded System, with tectonic and metamorphic events occurring during the entire Mid-Proterozoic interval.

5. Development of the marginal belts to the São Francisco Craton, during the Brasiliano Cycle, with tectonomagmatic event in the $700-450 \mathrm{Ma}$ age range.

The analysis of the Sr evolution diagrams shows that the Archean terrains are mainly formed by accretion from mantle-derived material, but crustal reworking is indicated by the high initial ${ }^{87} \mathrm{Sr} /{ }^{86} \mathrm{Sr}$ values of the Jequie Complex. The Transamazonian mobile belt include both types of materials, but the ${ }^{87} \mathrm{Sr} /{ }^{86} \mathrm{Sr}$ values, generally lower than those of the Jequie Complex, makes improbable a direct derivation. During Middle and Late Proterozoic the continental crust was already well consolidated, and reworking of crustal material predominated within the Espinhaço and Brasiliano Folded Systems.

SIGA JÚNIOR, Oswaldo

A evolução geotectônica da porção nordeste de Minas Gerais, com base em interpretaçōes geocronologicas. 28 de outubro. 140p. 1 vol. Orientador: Umberto Giuseppe Cordani.

Resumo: $\mathrm{O}$ presente trabalho objetivou demonstrar a potencialidade dos métodos $\mathrm{Rb}-\mathrm{Sr}, \mathrm{K}-\mathrm{Ar}, \mathrm{Pb}-\mathrm{Pb}$ e $\mathrm{U}-\mathrm{Pb}$, quando aplicados aos trabalhos básicos de levantamento geológico, permitindo através de diferentes valores interpretativos dessas metodologias contribuir para o entendimento dos processos tectônicos desenvolvidos na borda sudeste do Cráton do São Francisco (nordeste de Minas Gerais e parte sul da Bahia).

O acervo radiométrico processado representa uma ampla amostragem dos vários domínios litológicos caracterizados, contando com cerca de 230 determinações geocronológicas. $\mathrm{O}$ padrão de distribuição das idades radiométricas, em conjunto com as informações provenientes de outros campos das geociências, permitiu compartimentar a área em dois domínios geocronológicos maiores: o domínio brasiliano externo (ocidental) e o domínio brasiliano interno (centro-oriental).

No domínio brasiliano externo, expõem-se os metassedimentos de baixo grau metamórfico (fácies xisto-verde, zonas da clorita e biotita) da Faixa Araçuaí, tipificados principalmente pelos metadiamictitos do Grupo Macárbas. Tem ainda como representantes os metassedimentos do Sistema Espinhaço, claramente envolvidos pela tectônica brasiliana, além das rochas gnáissicas-migmatíticas da estrutura anticlinorial de Itacambira-Barrocão retrometamorfizadas neste período.

Os dados isotópicos $\mathbf{R b}$-Sr e $\mathrm{Pb}-\mathrm{Pb}$ disponíveis para a unidade gnáissica-migmatítica deste setor indicam geração de rochas no Arqueano ( 2.700 Ma.) e Proteroź́ico Inferior ( 2.100 Ma.). Os parâmetros $\left({ }^{87} \mathrm{Sr} / 86 \mathrm{Sr}\right)_{\mathrm{i}}$ e $\mu_{1}$ sugerem, adicionalmente, para as rochas analisadas uma origem por retrabalhamento de materiais com vida crustal anterior.

Os dados K-Ar (além de uma única datação por traços de fissão) possibilitaram delinear a história termal do domínio, sugerindo uma tectônica vertical, terminal ao Ciclo Brasiliano, que colocou lado a lado, blocos formados em diferentes profundidades.

O Ciclo Brasiliano como formador de crosta continental é característico do domínio interno, 
onde é representado pelos Metassedimentos Salinas e rochas gnáissicas-migmatíticas do setor oriental. Observa-se um metamorfismo crescente para leste, gradando da zona da cianita para a zona da sillimanita, atingindo na porção oriental condições $\mathrm{P}, \mathrm{T}$, do fácies anfibolito alto. Os dados radiométricos Rb-Sr e U$\mathrm{Pb}$ caracterizam a formação generalizada dessas rochas no período $660-570 \mathrm{Ma}$. As análises $\mathrm{K}$-Ar registram a permanência de porções aquecidas (temperaturas superiores a $250^{\circ} \mathrm{C}$ ) até pelos menos $480 \mathrm{Ma}$.

A atividade geodinâmica brasiliana é também representada por uma granitogênese de grande expressão no domínio interno, incluindo uma grande variedade de litotipos, normalmente ricos em álcalis. Os dados obtidos através dos métodos $\mathrm{Rb}-\mathrm{Sr}$ e U-Pb distribuiram-se num amplo intervalo de tempo(650$450 \mathrm{Ma}$.), representando episódios de caráter sin- a tarditectônicos (650 - $550 \mathrm{Ma}$.), tardi- a pós-tectônicos (550-500 Ma.) e pós-tectônicos a anorogênicos (500-450 Ma.). Adicionalmente, as evidências isotópicas de Sr apontam para uma evolução dessas rochas fortemente alicerçada em retrabalhamentos crustais nesses periodos.

Os dados K-Ar obtidos em biotitas dos diferentes maciços concentram-se no intervalo 500 $450 \mathrm{Ma}$., indicando o período de resfriamento das unidades em pauta.

Numa visão integrada Brasil-África, a geometria do cinturão brasiliano é condicionada claramente pelos Crátons do São Francisco e do Congo, que serviram de ante-país para a evolução das deformações desta faixa de dupla vergência. Verifica-se uma clara simetria em termos de zoneamento tectônico, em que terrenos de alto grau ocupam no Continente Africano posições ocidentais e os terrenos de médio a baixo grau colocam-se em posições mais externas, já próximas às coberturas de plataforma.

A evolução geotectônica deste cinturão é dominantemente ensiálica, sendo aqui interpretada com base em modelo de subduç̧ão A, ocorrida durante o Ciclo Brasiliano. Neste esquema propõe-se que a abertura (afinamento e quebramento rúptil da crosta superior) se estreite a norte, tomando o formato de uma cunha, cuja zona axial, de direção aproximadamente NNW/SSE pode ter evoluído sobre suturas anteriores, do Proterozóico Médio (herança Espinhaço).

Finalmente, a exumação do nível crustal mesocatazonal brasiliano é interpretado como decorrente de um processo em duas etapas, a primeira inerente a inversão da cadeia brasiliana e a segunda ocorrida no Meso-Cenozóico.

Abstract: This work tries to show the potential of the $\mathrm{Rb}-\mathrm{Sr}, \mathrm{K}-\mathrm{Ar}, \mathrm{Pb}-\mathrm{Pb}$ and $\mathrm{U}-\mathrm{Pb}$ methods applied to basic geological mapping. The different interpretative values of these methodologies contribute to the understanding of the tectonic processes developed in the southeastern border of the São Francisco Craton (northeastern Minas Gerais and southern Bahia).

The geochronological data for this region represents sampling of the several lithological units characterized and corresponds to about 230 determinations. The radiometric age distribution pattern together with other geological information suggest the subdivision into two main geochronological domains: the external Brazilian domain (at the western portion) and the internal Brazilian domain (at the centreeastern part).

In the external Brazilian domain occurs metasediments with low-grade of metamorphism (greenschist facies, chlorite and biotite zones) of the Araçuaí Belt, being typical the Macaúbas Group metadiamictites. Also represented are the Espinhaço System metasediments, clearly involved in the Brazilian tectonics, as well a gneissic-migmatitic rocks of the Itacambira-Barrocão anticlinal structure retrometamorphosed during this period.

The $\mathrm{Rb}-\mathrm{Sr}$ and $\mathrm{Pb}-\mathrm{Pb}$ isotopic data for the gneissic-migmatitic unit of this sector indicates their generation during the Archean $(\sim 2.7 \mathrm{Ga})$ and Early Proterozoic $(\sim 2.1 \mathrm{Ga})$. The $\left(\mathrm{Sr}^{87} / 86 \mathrm{Sr}\right)_{\mathrm{i}}$ and $\mu_{1}$ 
values also suggest an origin through reworking of older crustal rocks.

The K-Ar data (and one fission track datum) allow the thermal history of this domain to be delineated and suggest a vertical tectonic in the Late Brazilian Cycle, putting side by side blocks formed in different depths.

The Brazilian Cycle as a continental crust generator is characterized in the internal domain, where it is represented by the Salinas Metasediments and gneissic-migmatitic rocks of the eastern sector. An increasing metamorphism is observed towards east, grading from the kyanite towards the sillimanite zone reaching, in the eastern portion, PT conditions of the upper amphibolite facies. The Rb-Sr and U-Pb data indicates the generation of these rocks in the 660-570 Ma interval. The $\mathrm{K}$-Ar analyses indicates portions with temperatures above $250^{\circ} \mathrm{C}$ until at least $480 \mathrm{Ma}$.

The Brazilian geodynamic activity is also represented by an important granitogenesis in the internal domain including a large variety of lithotypes generally alkalic. The Rb-Sr and U-Pb data is distributed in a large time internal $(650-450 \mathrm{Ma}$.) representing sin to late tectonic $(650-550 \mathrm{Ma}$.), late to posttectonic (550-500 Ma) and posttectonic to anorogenic (500-450 Ma) episodes. The $\mathrm{Sr}$ isotopic data indicates crustal reworking for the generation of these rocks.

The K-Ar data in biotites of the different massifs are concentrated in the 500-450 Ma interval indicating the cooling of these units.

In a Brazil-Africa integrated vision the geometry of the Brazilian belt is cleary, conditioned by the São Francisco and Congo Cratons which served as foreland to the deformational evolution of this double vergence belt. There is a clear symmetry in terms of tectonic zoning in which the high-grade terrains occur in western portions of the African continent while the middle and low-grade terrains are situated in more external position, near the platform covers.

The geotectonic evolution of this belt is dominantly ensialic being interpreted here based in a model of A-type subduction during the Brazilian Cycle. In this model is proposed that an opening (thinning and ruptile breaking of upper crust) occurs and is smaller towards north (wedge-shaped) and its axial zone, with an approximately NNW/SSE direction, could have evolved over a Middle Proterozoic (Espinhaço) suture.

Finally, the Brazilian mesocatazonal province exhumation is interpreted as a two stage process, the first one related to the Brasilian Cycle and the later one occurring during the Meso-Cenozoic.

SOUZA FILHO, Edvard Elias de

Mapeamento faciologico do Subgrupo Itararé na Quadrícula Campinas (SP). 05 novembro. 121p. 1 vol. Orientador: Paulo Milton Barbosa Landim.

Resumo: Esta dissertação apresenta os resultados de um mapeamento geológico efetuado na quadrícula de Campinas, área de afloramentos do Subgrupo Itararé. Foram efetuados três modalidades de mapeamento, ou seja, o mapeamento litoestratigráfico, o mapeamento estrutural e por fim mapeamento faciologico ao qual foi dado maior ênfase, visto que ele permite a reconstrução paleogeográfica quando se utiliza os conceitos de sistemas deposicionais.

Foi possível, a individualização de sete unidades litoestratigráficas informais, denominadas: Unidade I (arenitos em granodecrescência ascendente), Unidade II (lamitos), Unidade III (lamitos e diamictitos), Unidade IV (arenitos), Unidade V (diamictitos e arenitos), Unidade VI (arenitos com Marcas 
Onduladas), Unidade VII (diamictitos vermelhos). O mapeamento estrutural permitiu a interpretação de estruturas de caráter local e sub-regional sob a forma de horsts e grabens que afetam os contatos da unidade, altos e baixos de caráter ainda não definidos, que ocorrem em vários locais da área de trabalho, e sistemas lineares de falhas e falhas isoladas, entre os quais o Sistema Linear de Cosmópolis, e os Sistemas de Santa Cruz da Boa Vista e o de Salto Grande.

O mapeamento faciológico permitiu a individualização de um grande número de fácies litológicas, agrupadas em fácies de arenitos, fácies de conglomerados, fácies de diamictitos, fácies de lamitos e fácies de calcários. Apesar dessas fácies ocorrerem em diversas posições estratigráficas e em diferentes unidades litoestratigráficas, o seu agrupamento em associações permitiu a interpretação de seis sistemas deposicionais cuja evolução originou o trato deposicional hoje preservado sob o nome de Subgrupo Itararé. Foram identificados dois sistemas glaciais, o Sistema Subglacial-proglacial de Campinas e o Sistema Supraglacial de Base Úmida de Monte Mor, o Sistema de Leques Subaquosos da Rodovia dos Bandeirantes, o Sistema de Plataforma de Hortolândia, o Sistema Deltaico da Rodovia do Açúcar, o Sistema de Leques Aluviais de Casa Branca e o Sistema Costeiro de Tupi.

Abstract: This paper shows the geologic mapping in the Itarare Subgroup that outcrops in the Campinas region. Three kinds of mapping were made: litostratigraphic mapping structural mapping, and faciologic mapping, ains at the paleogeographic reconstruction based in the depositional models concept.

Seven unity were identified: Unity I (fining upward sandstone), Unity II (mudstone), Unity III (mudstone and diamictites), Unity IV (sandstone), Unity V (diamictites and sandstones), Unity VI (ware rippled sandstone) and Unity VII (red diamictites).

The structural mapping attesting local and subregional horst, and grabens that affected the unity contacts, structural highs and lows in many places in this area, and linear and isolated fault system (e.g. the Cosmóspolis Linear System, the Santa Cruz da Boa Vista and Santo Grande Systems).

The faciologic mapping has defined many lithologic facies jointed in sandstone facies, conglomerate facies, diamictite facies, mudstone facies and limestone facies. In sptite of the stratigraphic position of these facies, its association has permitted the interpretation, of six depositional systems whose development settled out the depositional tract named Itarare Subgroup.

It were identified the Campinas Subglacial-Proglacial System, the Monte Mor Wet Based Supraglacial System, the Rodovia dos Bandeirantes Subaqueous Fan System, the Hortolândia Shelf System, the Rodovia do Açucar Deltaic System, the Casa Branca Alluvial Fan System and the Tupi Coastal System.

M-21

STEVAUX, José Cândido

Faciologia e ambientes de sedimentação da Formação Rio Bonito do Permiano da Bacia do Paraná. 22 de outubro. 99p. 1 vol. Orientador: Paulo Milton Barbosa Landim.

Resumo: Neste trabalho foram estudados os sedimentos da Formação Rio Bonito (P), Grupo Tubarão, em afloramentos na região de Rio do Sul (SC) e em testemunhos de sondagens (poços 2-AL-1-SC e 2-CS-1-PR), com o objetivo de caracterizar suas associações faciológicas e de determinar os ambientes deposicionais envolvidos na sua sedimentação. Para tanto, foram utilizadas descrições petrográficas (macroscópicas e microscópicas), descrição de afloramentos (geometria dos litossomas e estruturas sedimentares), descrição de testemunhos de sondagens, análise mineralógica de argila por meio de 
difratometria de raios $\mathrm{X}$, análise micropaleontológica, análise icnofossilífera, geoquímica de matéria orgânica e perfis geofísicos.

As associações faciológicas determinadas por meio de testemunhos de sondagem e/ou afloramentos, constituíram vários perfis verticais que, comparados com "motivos deposicionais" obtidos na literatura, puderam caracterizar diversos ambientes deposicionais.

Foram, dessa forma, determinados 8 ambientes deposicionais:

- Canais distributários e fluviais.

- Planície de inundação com depósitos de rompimento de dique marginal (crevasse splay).

- Canais e planície de maré.

- Planície de maré clástico-carbonática.

- Complexo barreira-laguna.

- Barras de costa-afora (offshore).

- Lobo deltaico.

- Baía interdistributária.

De modo geral estes ambientes deposicionais desenvolveram-se sob um clima que variou de sub-glacial a quente com tendências locais à aridez, numa bacia deposicional de energia relativamente baixa (golfo?), onde tempestades foram, provavelmente, o agente dinâmico mais eficiente.

trabalho.

O resultado obtido pela metodologia utilizada satisfez os propósitos estabelecidos neste

Abstract: It is studied in this paper the Rio Bonito Formation (P), Tubarão Group, through the outcrops in the Rio do Sul region (SC) and drill cores (wells 2-AL-1-SC and 2-CS-1-PR) with the aim of identifying its faciologic association and to determine the sedimentary environments that acted during the sedimentation.

Petrographic descriptions (macroscopic and thin section), outcrops and core descriptions, $\mathbf{X}$ ray diffraction analysis of clay minerals, micropaleontological analyses, icnofossiliferous analyses, organic geochemistry and electrical well logs are used in this work.

The comparison of the faciologic associations obtained from the description of outcrops and cores with the depositional models found in the literature allowed us to identify the following depositional environments:

- deltaic: distributary and fluvial channel, flood plain with crevasse splay, interdistributary bay delta front and prodelta.

- barrier island-lagoonal complex.

- clastic-carbonate tidal plain.

- tidal channel and plain.

- offshore (with offshore bars).

These depositional environments were submitted to sub-glacial ranging to hot climate with local tendency to aridity, in a low energy depositional basin (guilf?), where the storms were the major dynamic agent.

The results obtained by this method can be considered satisfactory.

SUBACIUS, Sandra Maria Rodrigues 
Estudo bioquímico e micropaleontologico do sílex negro da Formação Sete Lagoas, Grupo Bambuí (Proterozóico Superior), São Gabriel (GO), Brasil. 10 de janeiro. 149p. 1 vol. Orientador: Thomas Rich Fairchild.

Resumo: O estudo biogeoquímico da matéria orgânica (MO) amorfa e estruturada (microfósseis), associada a duas amostras de sílex negro (SG-1 e SG-2), finamente laminados, da Formação Sete Lagoas, Grupo Bambuí (Proterozóico Superior), da localidade de São Gabriel, Estado de Goiás (Brasil), revelou que:

1. A MO amorfa, que perfaz cerca de $0,12 \%$ do conteúdo total de carbono orgânico, é constituída por duas frações, solúvel e insolúvel, sendo que apenas o querogênio é singenético.

2. A fração solável (FS) alóctona provém de várias fontes, predominando a MO móvel migrada de sedimentos do Fanerozóico e de contaminações do solo, possivelmente de líquens.

3. Os querogênios SG-1 e SG-2, a despeito da idade do sedimento encaixante, possivelmente não seguiram o esquema clássico da maturação orgânica, uma vez que apresentam razões $\mathrm{O} / \mathrm{C}$ elevadas, incompatíveis com as razões $\mathrm{H} / \mathrm{C}$ (dentro da zona metagenética).

4. Os baixos graus de cristalinidade dos querogênios pesquisados são devidos aos seus altos teores em oxigênio, do qual grande parte está na forma de radicais do tipo quinona. Estes radicais. identificados pelo infravermelho e ressonância paramagnética do elétron, são responsáveis pela imobilidade da estrutura química dos querogênios mesmo quando foram aquecidos com o metamorfismo regional.

5. Os querogênios SG-1 e SG-2 exibem valores de $\delta^{13} \mathrm{C}(-27,2 \%$ e $-29,2 \%$ respectivamente), que sugere MO fotossintetizada e submetida a uma história térmica branda.

6. O fndice colorimétrico (marrom bem escuro) das organolitas, que indica MO senil, constitui a unica evidência do aquecimento tardio da MO com o metamorfismo regional.

7. Apesar da microflora preservada ser dominada por elementos alogênicos (fragmentos de colônias transportados do sítio de crescimento) e planctônicos, ambos querogênios derivam majoritariamente do decaimento de comunidades bentônicas fotoautotróficas, provavelmente responsável pela feição laminar da rocha carbonática original. Ambos querogênios exibem razões $\mathrm{O} / \mathrm{C}$ e H/C comparáveis aos querogênios proterozoicos húmicos do tipo IV.

8. A microflora preservada representa uma comunidade de microorganismos típica de fácies silicosas do Proterozoico Médio e Superior. Caracterizou-se em SG-1, sete taxa com afinidades com a Chroococcaceae, que incluem um gênero e uma espécie nova: Myxococcoides sp.a, $M$. sp.b; 2M. sp.; Sphaerophycus sp. Gloeodiniopis cf. G.lamellosa; Forma A; Unucellum bambuiense sp.n.; três taxa com afinidades com a Entophysalidaceae: Eoentophysalis sp.a, E. sp.b, e cf. E.arcata; cinco taxa incertae sedis: aff. Globophycus sp, aff. Caryophaeroides sp, aff. Zosterosphaera sp, Forma B, e Forma C.; e finalmente, quatro taxa com afinidades eucarióticas: ?Glenobotrydion aenigmatis, Forma D., Kildinella sp.a; $K$. sp.b. Na amostra SG-2 os microfósseis são mais escassos e estão representados por duas taxa filamentosas: 2Salome sp e Siphonophycus sp. e uma taxa com afinidades Chroococcaceae: Myxococcoides sp.

9. A presença de raros, mas muito bem preservados, exemplares de acritarcas de interesse bioestratigrafico, notadamente do gênero Kildinella sugere uma idade para a formação Sete Lagoas restrita ao Rifeano Superior e Vendiano Inferior (950-570 milhões de anos). Os acritarcas constitui também a primeira descrição formal de prováveis eucariontes no registro fóssil do Pré- Cambriano brasileiro.

Abstract: Biogeochemical study of amorphous and structured organic matter (OM) in two samples of thinly laminated black cherts from the Sete Lagoas Formation, Bambuí Group (Late Proterozoic), São 
Gabriel region, Goiás State, Brazil, has shown that:

1. The amorphous OM consists of a soluble fraction (SF) and an insoluble fraction (Kerogen), of which only the latter is syngenetic.

2. The allochthonous SF comes from several sources, mainly from soil contamination and Phanerozoic sediments.

3. The Kerogen in both samples (SG-1 and SG-2) exhibits high O/C ratios, incompatible with $\mathrm{H} / \mathrm{C}$ ratios in the metagenic interval that might be expected for samples of such great age. It thus appears that this Kerogen did not follow the classical sequence of organic maturation.

4. The low degree of crystallinity of the kerogens is due to the high oxygen content, which is largely concentrated in quinoid groups, as identified by infra-red spectrometry and electron paramagnetic resonance.

5. SG-1 and SG-2 kerogens have $\delta^{13} \mathrm{C}$ values of $-27.2 \%$ and $-29.2 \%$ respectively, suggestive of photosynthetic $O M$ that underwent a mild thermal history.

6. The color (dark brown) of the organopalynofacies indicates senile $O M$ and comprises the only evidence of late heating due to regional tectonism.

7. Although the preserved microbiota is dominated by allochthonous elements (colonial fragments) and planktonic forms, both kerogens were derived for the most part from photoautotrophic benthonic communities, probably responsible for the lamination in the original carbonate rock. SG-1 and SG-2 kerogens exhibits $\mathrm{O} / \mathrm{C}$ and $\mathrm{H} / \mathrm{C}$ ratios comparable to Proterozoic humic kerogens (type IV).

8. The São Gabriel microflora represent a microbial community of the chert-algal facies typical of the Middle and Upper Proterozoic. The association in SG-1 consists of seven taxa with chroococcacean affinities, including n. gen. et sp, Myxococcoides sp.a; M. sp.b; ?M. sp.; Sphaerophycus sp.; Gloeodiniopsis cf. G.lamellosa; Forma A; Unucellum bambuiense sp. n.; three taxa with entophysalidacean affinities; Eoentophysalis sp.a; E. sp.b; cf. E.arcata; five taxa incertae sedis: aff. Globophycus sp.; aff. Caryosphaeroides sp.; aff. Zosterosphaera sp.; Forma B and Forma C; and, finally, four taxa with eukaryotic affinities: ?Glenobotrydion aenigmatis; Forma D; Kildinella sp.a; $K$ sp.b. In SG-2 chert, the microfossils are scarce and are represented by two filamentous taxa: ?Salome sp. and Siphonophycus sp., and by one taxa with chroococcacean affinity: Myxococcoides sp.

9. The occurrence of rare but well-preserved acritarchs (Kildinella spp.) in the microflora is biostratigraphically significant in that it suggests a Late Riphean or Vendian age (950-570 Ma) for the Sete Lagoas Formation. This also comprises the first formal description of probably eukaryotic microfossils in the Brazilian Precambrian fossil record.

M-23

YAMAMOTO, Jorge Kazuo

Representações gráficas espaciais em geologia - aplicações no Complexo Alcalino de Anitápolis. 16 de junho. 167 p. 1 vol. Orientador: Gilberto Amaral.

Resumo: Esta dissertação apresenta os resultados de uma pesquisa realizada para se definir uma metodologia básica na obtenção automática de representações gráficas espaciais em geologia. Nela, as principais técnicas e conceitos matemáticos de computação gráfica, quais sejam: interpolação, definição da área de interesse, determinação da posição de um ponto em relação à área de interesse, contorno automático, projeção em perspectiva e eliminação de linhas ocultas, são descritos e discutidos. 
É proposto o uso de equações multiquádricas como método local para interpolação de dados dispersos tanto em duas como em três variáveis independentes.

As aplicações da metodologia apresentada foram feitas com os dados de topografia e dados de análises químicas da região do Complexo Alcalino de Anitápolis, SC.

Abstract: The main techniques and mathematical concepts of computer graphics, i.e., interpolation, determination of convex hull, determination of the position of point relative to convex hull, automatic contouring, perspective projection and hidden line elimination, are presented as a result of a study carried out in order to outline a basic methodology for computer aided graphical displaying of geological data.

The use of multiquadric equations locally applied to limited neighborhood together with adequate constant values for the interpolation of scattered data in two and three independent variables is proposed.

Applications over real topographical and chemical data from the Anitápolis Alkaline Complex, Santa Catarina State, are also discussed.

\section{7}

\section{BERTACHINI, Antonio Carlos}

Estudo das características hidrogeológicas dos terrenos cristalinos sob clima úmido na regiāo de Jundiaí, em São Paulo. 04 de dezembro. 105p. 1 vol. Orientador: Mária Szikszay.

Resumo: Foram utilizadas técnicas de análise hidrogeológica, hidroquímica, geológico-estrutural e morfologica para compreender o comportamento hidrogeológico dos terrenos cristalinos da região de Jundiaí, SP. Os resultados obtidos demonstram a influência das condições climáticas atuais e pré-atuais, evidenciada pela própria geometria do aqǘf́ero com a presença de um espesso manto de alteração com valores mais freqüentes de espessura entre $10 \mathrm{~m}$ e $40 \mathrm{~m}$ e coeficiente de armazenamento entre 0,03 e 0,005 . Estes valores conferem ao manto, de alteração saturado uma capacidade de armazenamento bem superior à encontrada no meio fraturado. O manto de alteração desta forma possibilita a acumulação de reservas renováveis da ordem de $200 \mathrm{~mm}$ /ano. A ação do clima úmido se faz sentir também na evolução da composição química das águas subterrâneas, as quais apresentam-se pouco mineralizadas, com concentrações dos sólidos totais dissolvidos abaixo de $300 \mathrm{mg} / \mathrm{l}$. Estas águas são fortemente bicarbonatadas, mistas ou cálcicas e refletem diretamente os produtos da hidrólise com a influência da litologia ou processos de modificação da composição química. A morfologia dos terrenos influencia as condições climáticas e a distribuição das espessuras do manto de alteração. A permeabilidade do meio fraturado está diretamente associada à gênese do fraturamento, sendo que os fraturamentos desenvolvidos ao longo das direções N45E, N85W, N50W, N-S e N65E apresentam maior potencialidade com valores mais elevados da capacidade específica. Existe na região de Jundiaí uma variação espacial da densidade e da 
freqüência dos fraturamentos, com as zonas mais fraturadas situadas no extremo sudeste da área ou a norte do falhamento que corta a área de noroeste para sudeste. Os recursos exploráveis são da ordem de 100 $\mathrm{mm} /$ ano ou $1.0 \times 10^{5} \mathrm{~m}^{3} / \mathrm{km}^{2}$, sendo que nas áreas mais fraturadas podem atingir até $200 \mathrm{~mm}$ /ano ou $2.0 \mathrm{x}$ $10^{5} \mathrm{~m}^{3} / \mathrm{km}^{2}$.

Abstract: In this study the hydrogeological, hydrogeochemical, structural and morphological analysis techniques were used with the objective to understand the hydrogeological comportment of crystalline terrains in the Jundiaí region, São Paulo. The final results showed the strong influence of the climate in last seven thousand years and the actual climate with evidence in the aquifer geometry and by the presence of the weathered layer with most frequent values of thickness between $10-40 \mathrm{~m}$ and a storage coefficient between $0.03-0,005$. These values confer to the weathered and saturated layer a storage capacity superior as to the fractured part. This way, the weathered layer makes possible the accumulation of renovable reserves of cca $200 \mathrm{~mm} /$ year. The action of the humid climate can be observed also in the evolution of the chemical composition of the groundwater, being their mineralization of less importance with the total dissolved solids concentration below $300 \mathrm{mg} / 1$. These waters are strongly bicarbonated, mixed or calcic waters and directly reflect the products of hydrolysis with the influence of the lithology or of the modifying processes of the chemical composition. The morphology influences the climate and the distribution of the weathered layer's thickness. The permeability of the fractured part is directly associated with the origin of the fractures, being that those fractures developed with the directions of N45E, N85W, N50W, N-S and N65E, present a greater potentiality with higher values of special capacity. There is in the Jundiaí region a variation of density and frequency of fractures in space, with the more fractured zones situated at the extreme southeast of the area or north of the fault which separates the area from northwest to southeast. The explorable resources are of $100 \mathrm{~mm} /$ year or $1.0 \times 10^{5} \mathrm{~m}^{3} / \mathrm{km}^{2}$, being that in the more fracture area they can reach $200 \mathrm{~mm} /$ year or $2.0 \times 10^{5} \mathrm{~m}^{3} / \mathrm{km}^{2}$.

\section{M-25}

FRAGA, Carlos Gilberto

Introdução ao zoneamento do Sistema Aqürfero Serra Geral no Estado do Paraná. 03 de julho. 125p. 1 vol. Orientador: Aldo da Cunha Rebouças.

Resumo: Através da descrição e interpretação de perfis litológicos de poços pré-selecionados, bem como do condicionamento hidráulico de cada obra, foi possível, introdutoriamente, caracterizar o zoneamento hidrogeológico do Sistema Serra Geral, no Estado do Paraná. A área de estudo abrange uma superfície de aproximadamente $104.000 \mathrm{~km}^{2}$.

Dentro deste contexto, o significado hidrogeológico de cada unidade, aqui reconhecida, é traduzido pela capacidade especifica dos poços e pela extensão lateral dos seus valores e outras características locais. A morfogênese dos derrames basálticos, e os efeitos da tectônica sobre estes constituem os elementos básicos para a análise, classificação e delimitação de áreas mais produtoras. $\mathrm{O}$ número de derrames penetrados e a espessura útil produtora são fatores condicionantes principais da freqüência e do posicionamento das entradas de águas nos poços.

Assim sendo, o Sistema Aqǘfero Serra Geral pode ser dividido inicialmente, no Estado do Paraná, em dois grandes compartimentos: Serra Geral Norte e Serra Geral Sul, entendido este último como aquele relacionado à porção abrangida pela bacia do Rio Iguaçu, englobando áreas de ocorrência, 
tanto das rochas básicas como dos "diferenciados ácidos" e zonas de bordo da formação. A notória diferença da produtividade média dos poços entre os dois grandes compartimentos hidrogeológicos, Área Norte e Área Sul, pode ser explicada por diferenças estruturais nos derrames. Na Área Norte, os derrames profusamente vesiculares e de espessura menor foram preservados, provavelmente, pelo capeamento sedimentar pretérito da Formação Caiú. Na Área Sul, o modelado de relevo é mais irregular. Trata-se de uma unidade geomorfologicamente mais dissecada, apresentando vales muito profundos e de escarpas abruptas. É possível que esse processo de intenso dissecamento tenha proporcionado o afloramento de derrames mais antigos e espessos.

Do ponto de vista hidroquímico, o Sistema Serra Geral, no Estado do Paraná, é representado por três fácies: (I) Fácies de águas bicarbonatadas sódicas, (II) Fácies de águas bicarbonatadas calciomagnesianas e (III) Fácies de águas bicarbonatadas cálcicas. Os dois últimos estão relacionados à natureza das estruturas armazenadoras dos derrames basálticos e à sua litoquímica. Já a formação do primeiro, parece estar mais relacionada às influências locais do Aqüifero Botucatu subjacente.

Abstract: Based on the description and interpretation of lithological profiles of various selected wells and on the hydraulic conditions of each, it was possible to characterize hydrogeological zones of the Serra Geral System in the Paraná State, Brazil.

The area of study comprised an extension of $104,000 \mathrm{~km}^{2}$. To define the hydrogeological peculiarities of each unit by extrapolation of the wells specific capacity additional local characteristics were used.

Basic elements for the analysis, classification and definition of the regions with a higher yield were morphogenetic and tectonic studies of the basaltic layers. The number of the penetrated layers and the extension of their productive sections are the governing parameters for the frequency and the location of water inlets of the wells.

Thus the Aquifer System Serra Geral can be divided initially into two compartments: the Serra Geral Norte and the Serra Geral Sul, where the latter includes the drainage basin of the Iguaçu river, thus representing areas of basic rocks as well as of the differentiated acid rocks and their respective contact zones.

The distinat difference between the two hydrogeological compartments in terms of average productivity of their wells can be explained by structural differences of the basaltic layers. In the northern area the highly vesicular layer of minor thickness probably had been preserved in the past by the sedimentary layer of the Caiuá Formation.

In the southern area the landscape's relief demonstrates a higher irregularity with deep valleys and steep escarpements due to intensive linear erosion. It is possible that this intensive process caused the appearance of older and thicker basaltic layers.

From a hydrochemical point of view the Serra Geral System is represented by three facies: (I) Facies of sodium-bicarbonate waters, (II) Facies of calcium-magnesium-bicarbonate waters, (III) Facies of calcium-bicarbonate waters.

The latter two are highly correlated to the storage structures of the basaltic layers and their geochemistry, while the other appears to be related to local influences of the subjacent Botucatu Formation.

\section{GIANNINI, Paulo César Fonseca}


Sedimentação quaternária na planície costeira de Peruíbe - Itanhaém, SP. 17 de junho. 234p. 2 vol. Orientador: Kenitiro Suguio.

Resumo: Este trabalho contém uma caracterização sedimentológica dos depósitos marinhos, com ênfase aos sedimentos arenosos, aflorantes ao longo da planície costeira de Peruíbe-Itanhaém, envolvendo basicamente distribuição granulométrica, mineralogia e morfometria.

A planície costeira de Peruíbe-Itanhaém constitui-se numa faixa de cerca de $25 \mathrm{~km}$ de extensão contínua de sedimentos quaternários regressivos situada no litoral sudoeste do Estado de São Paulo, apresentando largura variável desde 4 até $14 \mathrm{~km}$ e altitudes entre 0 e $14 \mathrm{~m}$. Tem como fronteiras naturais a Serra de Peruíbe (subsidiária da Serra do Itatins), a SW, o Morro do Poço de Anchieta e os Morros Boturuçu, Araraf́, e Novo Mundo, a NE, e a Serra das Laranjeiras (subsidiária da Serra do Mar), na parte interior.

Entre o flanco norte da Serra de Peruibe e a porção meridional da Serra das Laranjeiras, define-se, parcialmente controlado por lineamentos associados à Falha de Itariri, o sistema flúviopaleolagunar dos Rios Preto e Branco de Peruibe, enquanto na extremidade oposta da planície (NE), ocorre outro sistema semelhante, compreendendo os rios homônimos de Itanhaém. Estes dois sistemas flúvio-paleolagunares constituem as únicas zonas de sedimentação areno-lamosa aflorantes na planície, apresentando-se nas demais áreas extenso lençol de sedimentos tipicamente arenosos (\% fração areia > 94\%). A continuidade deste lençol arenoso é interrompida apenas por pequenos afloramentos do embasamento cristalino na região de Bairro dos Prados e Abarebebê cujo caráter paleolagunar pleistocênico é sugerido pela presença, em furos de sondagem, de níveis métricos de material pelítico escuro. Mais a NE, o cristalino volta a aflorar na Pedra dos Jesuítas, hoje ainda ilhada pelas águas, notando-se localmente ligeiro encurvamento no alinhamento de paleocordões holocênicos.

A porção arenosa da cobertura sedimentar da Planície de Peruibe-Itanhaém pode ser subdividida em três faixas paralelas à linha de costa: a faixa dos sedimentos holocênicos de praia atual (últimos 3.000 anos), com 50 a $100 \mathrm{~m}$ de largura, a faixa dos sedimentos holocênicos interiores (5.500 e 3.000 anos A.P.), com largura de até $1,5 \mathrm{~km}$ e a faixa de sedimentos pleistocênicos, com largura variável, porém sempre superior a das duas faixas mais externas.

A distinção, a nível sedimentológico, entre estas três unidades de sedimentos regressivos foi um dos objetivos deste trabalho, tendo-se coletado, para isso, 26 amostras na faixa praial, 17 na faixa holocênica interior e 54 na área pleistocênica, além de 16 amostras de regolito das zonas de afloramento cristalino circunjacentes e de sedimentos fluviais, destinadas à inferência de áreas-fontes através de estudos de minerais pesados. Sedimentos areno-lamosos do sistema flúvio-paleolagunar não constituíram interesse central desta pesquisa, tendo-se amostrado apenas 5 pontos na região de Peruíbe especificamente relacionada à deposição da lama negra extraída para uso cosmético e medicinal. Nestas 5 amostras, além dos estudos morfométricos, granulométricos e mineralógicos, efetuou-se um fracionamento de material coloidal e argiloso, com dosagem de matéria orgânica e difratometria semiquantitativa de argilominerais por fração.

O tratamento matemático-estatístico dos resultados granulométricos, visando sua interpretação, incluiu a obtenção dos quatros momentos, segundo método gráfico clássico de Folk e Ward, tendo-se subseqüentemente utilizado estes momentos para a confeç̧ão de diagramas binários de dispersão, diagrama de Sahu por unidade sedimentar, correlação linear paramétrica de Pearson com coordenadas geográficas e mapas de superfície de tendência de regressão múltipla. Parâmetros mineralógicos de diferentes unidades sedimentares foram comparados entre si pelo método do qui-quadrado $\left(\mathrm{X}^{2}\right)$, além de 
submetidos a testes de correlação linear com a coordenada geográfica, estes aplicados também às variáveis morfométricas.

A variação dos parâmetros granulométricos estatísticos ao longo da planície, avaliada nos testes de correlação linear e nas superfícies de tendência, sugere que os sedimentos arenosos das três faixas regressivas foram transportados e depositados por correntes de deriva longitudinal, orientadas segundo o mesmo rumo observado hoje, isto é, de SW para NE. A influência destas correntes na sedimentação não teve, todavia, a mesma intensidade nas diferentes faixas, indicando que outro(s) fator(es) deve ter incidido com importância variável no decorrer da história deposicional. Estudos de proveniência de certos minerais pesados (andaluzita, cianita, estaurolita), revelando sedimentos submersos da plataforma continental como área-fonte provável, permitem apontar a migração transversal de material da antepraia, induzida por abaixamento do nível relativo do mar, como segundo fator de sedimentação.

De acordo com a variação de importância relativa das correntes SW-NE no tempo, diagnosticada pela maior ou menor nitidez na queda do parâmetro desvio-padrão ao longo desse rumo, e de acordo com a variação de abundância de pesados oriundos da plataforma continental, a atuação da deriva litorânea na sedimentação foi mais efetiva durante a formação da faixa holocênica interna. As areias desta faixa foram depositadas presumivelmente durante o período de nível relativo do mar quase constante ocorrido entre 5.500 e 3.000 anos A.P., logo após o auge da Transgressão Santos. Entre 3.000 e 1.800 anos A.P., fase para a qual se admite um abaixamento suave, porém contínuo de nível relativo do mar, teria ocorrido a sedimentação da faixa de praia atual, com retrabalhamento por vaivém intensificado nos últimos 1.800 anos. Estes fatores teriam encoberto a influência de correntes de deriva, justificando a pouca evidência de seleção longitudinal nas areias praiais modernas. Conforme ilustrado pelo Diagrama de Sahu, as condições energéticas de deposição destas areias diferem sensivelmente das condições deposicionais das areias holocênicas internas e pleistocênicas, sugerindo uma sedimentação praial contemporânea preponderantemente comandada pelo espraiamento, em contraste à sedimentação mais antiga, que se deu principalmente ao longo de barras de arrebentação, parte delas preservada na forma de alinhamentos de cordões.

Variações geográficas nos parâmetros granulométricos, evidenciadas através dos mapas de tendência, indicam que a evolução, por acresção sedimentar, da geomorfologia costeira da planície, refletiuse nas características da própria sedimentação. No início da regressão pleistocênica, as encostas dos morros de Boturuçu, Araraú e Novo Mundo, no extremo nordeste da paleocosta, criaram condições locais de praia de alto declive, tipo reflexivo, favorecendo o aumento de diâmetro médio no rumo da deriva. Com a progradação gradativa da costa, o declive da praia a NE baixou até igualar-se ao da região de Peruibe, tornando a praia tipicamente dissipativa (queda de diâmetro médio no rumo da deriva) em toda extensão ainda no decorrer da regressão .pleistocênica. No Holoceno, quando a linha de costa, em seu avanço progressivo rumo ao mar, atinge, a NE, o afloramento de cristalino do Morro do Poço, surge nesse local, um efeito de bloqueio e anulação de correntes de deriva, com conseqüências granulométricas e geomorfológicas visíveis.

A seleção granulométrica e morfométrica na fração areia de sedimentos da zona flúviopaleolagunar de Peruíbe, é inferior a das areias do lençol que recobre maior parte da planície, reconhecendo-se a existência de áreas-fontes distintas à jusante e a montante dos depósitos psamopelíticos. Semiquantificação de argilominerais e dosagem de matéria orgânica executados nas frações argilosa e coloidal destes sedimentos, evidenciam origem predominantemente continental (detrítica) para a matéria argilorgânica da fração argila e origem por amadurecimento secundário in situ (neoformação e transformação) para a matéria argilorgânica coloidal. 
Abstract: This work contains a sedimentological characterization of marine deposits, with emphasis to sandy sediments, outcropping along the Peruibe-Itanhaém coastal plain, involving basically granulometrical distribution, mineralogy and morphometry.

Peruibe-Itanhaém coastal plain consists in a continue strip of Quaternary regressive sediments situated in the southeast littoral of São Paulo State, with $25 \mathrm{~km}$ of extension, width variable from 4 to $14 \mathrm{~km}$ and altitudes oscillating between 0 and $14 \mathrm{~m}$. This plain is bordered by the Serra de Perube (subsidiary of Serra do Itatins), to SW, the Morro do Poço de Anchieta and Boturuçu, Araraú and Novo Mundo mounts, to NE, and the Serra das Laranjeiras (subsidiary of Serra do Mar), in the internal side.

Between the north boundary of Serra de Peruibe and the southern portion of Serra das Laranjeiras, the fluvial-paleolagoonal system of Preto and Branco rivers of Peruibe occurs, partially controlled by lineaments associated to Itariri Fault. On the opposite extremity of the plain (NE), another similar system takes place, comprising the homonymous rivers of Itanhaem. These two fluvialpaleolagoonal systems are the unique zones of sand-muddy superficial sedimentation in the plain since as in other places an extense sandy sheet is present (\% sand $>94 \%)$. The continuity of this sandy sheet is interrupted only by small crystalline rocks outcrops at Bairro dos Prados and Abarebebê region. A paleolagoonal character to this region is suggested by the presence, in sondage holes, of metric banks of dark pelitical material. Towards NE, the crystalline basement turns to outcrop at Pedra dos Jesuitas, that is still nowadays an island, and it is observed locally a light arching in the alignment of holocenic paleostrings.

The sandy portion of sedimentary covering of Peruibe-Itanhaém Plain can be subdivided into three strips that are parallel to the coastline: the strip of modern shore holocenic sediments (last 3,000 years), 50 to $100 \mathrm{~m}$ wide; the strip of internal holocenic sediments (5,500 to 3,000 years B.P.), till $1.5 \mathrm{~km}$ wide, and the area of pleistocenic sediments, with variable width, but always bigger than the widths of externer strips.

The distinction, at sedimentological context, among these three regressive sedimentary unities was one of the purposes of this work, having been collected for this 26 samples along the shore strip, 17 samples along the internal holocenic strip and 54 samples in the pleistocenic area. Additionally 16 samples of regolith were collected in the neighboring crystalline zones and fluvial deposits, designed to the inference of source areas through heavy minerals studies. Sand muddy sediments from fluvial paleolagoonal systems did not constitute subject of central interest in this work, having been shown only 5 points at the specific region of Peruibe related to deposition of lama negra (black mud) extracted for cosmetic and medicinal uses. These 5 samples, besides morphometrical, granulometrical and mineralogical studies, were submitted to separation of clayey and colloidal fractions, with organic matter determination and semiquantitative diffractometry of clay minerals by fraction.

The mathematical and statistical treatment of granulometrical results comprised the obtention of the four moments, according to the classical graphic method of Folk and Ward, having been used these moments to the construction of dispersion binary diagrams, Sahu diagram by sedimentar unity, linear parametric correlation of Pearson with geographic coordinates and trend surface maps of multiple regression. Mineralogical parameters of different sedimentar unities were compared by $\mathrm{X}^{2}$ method and were subjected to tests of linear correlation with geographic coordinates, these tests being applied to morphometrical variables, too.

The variation along the plain of granulometrical statistical parameters, evaluated by linear correlation tests and trend surface analysis, suggests that the sandy sediments of the three regressive strips were transported and deposited by longshore currents, orientated according to the same direction observed nowadays i.e., from SW do NE. The influence of these currents over the sedimentation have not had the 
same intensity at the different strips, indicating that other agents must have acted with variable importance along of the depositional history. Provenance studies of certain heavy minerals (andalusite, kyanite, staurolite), revealing submerse sediments of continental shelf as probable source area, indicate the transversal migration of offshore material, induced by lowering of relative sea level, as a second factor of sedimentation.

According to the variation in time of relative importance of SW-NE currents, diagnosticated by the bigger or smaller sharpness in the decrease of standard deviation parameter along this bearing, and according to the variation in abundance of heavy minerals derived from the continental shelf, the action of longshore drift on the sedimentation attained its largest effectiveness during the formation of internal holocenic strip. The sands of this strip were deposited presumably during the period of almost constant relative sea level occurred between 5,500 and 3,000 years B.P., just after the peak of Santos transgression. Between 3,000 and 1,800 years B.P., period to which was admitted a weak and continuous lowering of relative sea level, would have occurred the sedimentation of the modern beach strip, with a reworking by swash and backwash intensified along the last 1,800 years. These factors would have hidden the influence of longshore currents, justifying the scarce evidence of longitudinal sorting in modern beach sands. According to the illustration by the Sahu Diagram, the energetic conditions in deposition of these sands differ sensibly to depositional conditions of pleistocenic and internal holocenic sands, suggesting that the beach contemporaneous sedimentation is commanded by beach spreading, in contrast to more ancient Quaternary sedimentation, that was essentially along surfing bars, today partially preserved in alignments of strings.

Geographic variations in granulometrical parameters, evidenced by trend surface maps, indicate that the evolution of coastal geomorphology by sedimentary accretion reflected on the characteristics of the sedimentation. In the beginning of the pleistocenic regression, the hillside of Boturuçu, Araraú and Novo Mundo mounts, placed in the northeast extreme of the paleocoast, would have created local conditions to high slope (reflexive type) beach, propitiating the increase of mean grain size in the bearing of the longshore drift. With the gradative progradation of the coast, the beach slope to NE would have lowered till equalizing to the Peruibe region, making the beach typically dissipative (decrease of mean grain size in the bearing of drift) along its whole extension, yet during the pleistocenic regression. In the Holocene, when the coastline continues its progressive advance into the sea and attains, to NE, the crystalline outcrop of Morro do Poge, appears at this local, an effect of obstruction and annulment of longshore currents that has granulometrical and geomorphological consequences.

The granulometrical and morphometrical sorting in the sand fraction of the fluvialpaleolagoonal sediments of Peruibe is inferior to the sorting of the sands of the sheet that covers the biggest part of the plain, suggesting the existence of distinct source area to upstream and downstream of tide currents. Semiquantification of clay minerals and organic matter determination, made on clayey and colloidal fractions of these sediments, evidence a predominantly continental (detritical) origin for the clayorganic material of clay fraction and a secondary origin by maturing in situ (neoformation and transformation) for the colloidal clay-organic material.

GUIMARÄES, Ignez Gomes

Petrologia da formação ferrífera na área Salobo $3 A$ - província mineral de Carajás. 15 de dezembro. 99p. 1 vol. Orientador: Vicente Antonio Vitorio Girardi. 
Resumo: A área Salobo 3A situada a norte da Serra dos Carajás, é constituída por uma seqüência vulcano-sedimentar de idade Arqueana cuja formação ferrífera engloba a Jazida de Cobre Salobo 3A da Província Mineral dos Carajás. Esta formação ferrífera é produto de sedimentação primária, diagênese, metamorfismo e retrometamorfismo de BIF de fácies carbonato-sulfeto.

Dados analíticos de 14 elementos comuns em 34 amostras utilizados estatisticamente sugerem o tipo Algoma e o fácies primitivo carbonato-sulfeto para a formação ferrífera quimicamente equivalente a BIF. A partir do fácies assim obtido, associado aos dados petrográficos os quais incluem todas as litologias até agora conhecidas, elaboram-se hipóteses sobre a evolução diagenética e metamórfica da formação ferrífera.

O metamorfismo regional progressivo atingiu cerca de $650^{\circ} \mathrm{C}$ e pressão da ordem de 4,5 kbar, resultando no desenvolvimento de duas associações diagnósticas: a) grunerita + almandina \pm magnetita \pm quartzo; e, b) fayalita + magnetita + grafita, esta quimicamente equivalente a BIF.

A primeira fase retrometamórfica ocorreu no fácies anfibolito e caracteriza-se principalmente pela transformação de fayalita em grunerita + magnetita, sem a presença do quartzo, na segunda das associações diagnósticas supra-citadas.

Retrometamorfismo de fácies xisto verde atingiu, posteriormente, ambas as associações diagnósticas gerando a paragênese minnesotaita + greenalita a partir de fayalita e grunerita.

São formuladas hipóteses sobre as transformações ocorridas no minério face ao desenvolvimento geológico da área.

Abstract: The Salobo 3A area situated in the north of Serra dos Carajás is constituted of a vulcanicsedimentary sequence of Archean age whose iron-formation comprise the Salobo 3A Copper Mine of the Carajás Mineral Province. This iron-formation is a product of a primary sedimentation of a diagenesis, of a metamorphism and of a retrograde metamorphism of the carbonate-sulphide facies BIF.

Analytic data of 14 common elements in 34 samples, statistically treated, suggest the existence of iron-formation primitive facies type (BIF). From the facies type so obtained associated with the petrographic data, which include all the lithology so far known, hypothesis are worked up concerning the diagenetic evolution and the metamorphic iron-formation.

The regional progressive metamorphism attained to about $650^{\circ} \mathrm{C}$ and to a pressure of about $4.5 \mathrm{kbar}$, leading to the development of two diagnostic associations: a) grunerite + almandine \pm magnetite \pm quartz; b) fayalite + magnetite + graphite. The later is the only one chemically equivalent to BIF.

The first retrograde metamorphic stage took place at the amphibolite facies and characterizes mainly by the fayalite transformation into grunerite + magnetite, without the quartz presence in the second diagnostic association mentioned above.

The green schist facies retrograde metamorphism reached both diagnostic associations, afterwards, generating the minnesotaite + greenalite paragenesis from the fayalite and grunerite.

Some hypothesis are enounced about the transformations of the ore minerals in relation to the area geologic development.

KARMANN, Ivo

O Grupo Rio Pardo (Proteroź́ico Médio a Superior): uma cobertura paraplataformal da margem sudeste do Cráton do São Francisco. 03 de setembro. 129p. 1 vol. Orientador: Roland Raymond Trompette. 
Resumo: A bacia do Grupo Rio Pardo localiza-se na margem sudeste do Cráton do São Francisco, marcando a transição do domínio cratônico para o de faixa dobrada nesta área.

O Grupo Rio Pardo inicia-se na base com metapsefitos e psamitos imaturos da Formação Panelinha, depositados em leques aluviais com correntes detríticas subaquáticas, associados a um relevo acidentado conseqüente do abatimento de blocos e formação de bacias do tipo graben ou hemigraben. Sugere-se que a subsidência destes blocos crustais ocorreu devido a um regime tracional da crosta siálica, relacionado provavelmente com a intrusão de diques básicos, freqüentes no embasamento da bacia, datados por volta de $1.100 \mathrm{Ma}$.

Seguiu-se uma fase de calmaria tectônica, com transgressão dos metapelitos, metapsamitos finos e rochas metacarbonatadas com intercalações psamíticas dos Membros Camacã, Água Preta, Serra do Paraíso e Santa Maria, que constituem variações faciológicas laterais da Formação Itaimbe. Os dois primeiros representam um sistema deposicional deltaico, com um fácies proximal de planície deltaica que passa para o frontal mais interno da bacia. Os Membros Serra do Paraíso e Santa Maria correspondem a um depósito de plataforma marinha carbonática com fácies de planície de maré e zonas mais profundas, adjacentes ao sistema deltaico.

A Formação Salobro, topo da Seqüência do Rio Pardo, com metapsamitos, metapelitos e metapsefitos imaturos, é produto de uma fase epirogenética do embasamento com reativação de falhamentos normais, que produziram um relevo emerso, que condicionou a erosão parcial das unidades subjacentes, alimentando fluxos detríticos subaquáticos, com caráter turbidítico. A estratigrafia aqui apresentada, com somente três formações, difere das várias colunas recentemente propostas com no mínimo cinco formações, devido às evidências de importantes variações faciológicas e repetições tectônicas.

Compartimentou-se a bacia do Grupo Rio Pardo, em duas unidades litoestruturais. A Unidade Litoestrutural 1 abrange o setor nordeste da bacia, sendo limitada a sudoeste pela Falha Inversa Rio Pardo-Água Preta de direção NW-SE e vergência para NE. Caracteriza um bloco autóctone com dobramentos abertos e clivagem ardosiana a norte, que se intensificam no sentido SW, através da presença de megadobras inversas e xistosidade, associadas à $1^{\text {a }}$ fase de deformação. Esta causou um encurtamento de no máximo $15 \%$ na cobertura metassedimentar. A unidade litoestrutural 2 inicia-se a sudoeste da Falha Inversa Rio Pardo-Água Preta, caracterizando um bloco subautóctone com dobramentos fechados relacionados principalmente à $2^{\mathrm{a}}$ fase de deformação e com transporte tectônico para NE. $\mathrm{O}$ encurtamento devido à $2^{\mathrm{a}}$ fase foi avaliado em 35 a $40 \%$, o que condicionou um descolamento generalizado da cobertura metassedimentar deste bloco. Registrou-se, localmente nesta unidade, um terceiro evento deformacional com vergência ENE e dobras locais de $3^{\mathrm{a}}$ fase, sendo conseqüente da tectônica compressiva de blocos do embasamento ao longo de falhamentos inversos NS na borda oeste da bacia e localmente no interior da mesma.

O metamorfismo da bacia está associado à $1^{\text {a }}$ fase de deformação, sendo crescente de NE para SW, desde o grau incipiente, atingindo o grau fraco na Unidade Litoestrutural 2, caracterizando um metamorfismo regional intermediário do tipo Barroviano na zona da clorita e biotita.

A idade máxima do Grupo Rio Pardo foi restringida a cerca de $1.100 \mathrm{Ma}$. (final do Proteroz6ico Médio), sendo a idade de $550 \mathrm{Ma}$. mínima, correspondente ao metamorfismo do Ciclo Brasiliano.

Em função da ausência de magmatismo, das características litológicas e estruturais da bacia, conclui-se que o Grupo Rio Pardo constitui uma cobertura cratônica gerada no final do Proterozóico Médio e início do Superior, num regime paraplataformal do Cráton do São Francisco. Posteriormente sofreu parcialmente a tectogênese brasiliana, associada à instalação da Faixa de Dobramentos Araçuaí, adjacente a 
borda sudeste do cráton. Nesta fase, a bacia do Grupo Rio Pardo insere-se num contexto de antepaís, em relação à Faixa Araçuaí. O limite geológico do Cráton do São Francisco nesta área foi traçado ao longo da Falha Inversa Rio Pardo-Água Preta, que limita o domínio de faixa dobrada da região considerada pericratônica a cratônica. A Unidade Litoestrutural 2 pertence portanto à Faixa Araçuaí.

No contexto do Cráton do São Francisco, correlacionou-se as Formações Salobro e Bebedouro, em função de suas semelhanças litológicas e devido à presença, na base de ambas de uma importante discordância erosiva, conseqüente de uma fase epirogenética generalizada do cráton no final do Proterozóico Médio. Esta discordância marca o topo do Grupo Chapada Diamantina e a base da Formação Bebedouro na cobertura do cráton (distante do Rio Pardo de $240 \mathrm{~km}$ ), como também das unidades correlatas no domínio da Faixa Araçuaí. Desta forma, as formações Panelinha e Itaimbé são correspondentes, estratigraficamente, às unidades superiores do Grupo Chapada Diamantina e Supergrupo Espinhaço.

Em relação às unidades da Faixa do Congo Ocidental, que constituem juntamente com a Faixa Araçuaí um orógeno brasileiro/pan-africano intracontinental com vergência centrifuga, o Grupo Rio Pardo é correlacionado aos Grupos Sansikwa e Haut Shiloango, ou à parte superior do Subgrupo Mayombiano e parte inferior do Supergrupo Oeste Congoliano.

Abstract: The Proterozoic Rio Pardo Group, located in the southeastern part of Bahia State, begins with the immature coarse clastics of the Panelinha Formation, formed by alluvial fans and subaqueous debris flows. The subsidence of its granulitic basement resulted probably from tractional stress in the crust, with associated normal faulting and intrusion of basic dikes. These are at least 1,100 $\mathrm{Ma}$ old, from the radiometric evidence.

The overlying Itaimbe Formation is related to a transgression during a period of low tectonic activity. It is made up of the Camacã (metapelites with local carbonates), Água Preta (fine metapsammites and local carbonates), Serra do Paraíso and Santa Maria (metapsammites interstratified with metacarbonates) Members. The general environment seems to have been a deltaic system adjacent to a marine carbonate platform, with tidal flats and shallow marine siliclastic facies.

The Salobro Formation consists of immature coarse and local fine clastic rocks, disconformably overlying the Itaimbe Formation. The rocks were mainly deposited as subaqueous debris flows with local turbidites, within a submarine fan system.

The three fold stratigraphy here proposed for the Rio Pardo Group, differs from the already existent stratigraphic columns, all then with at least five formations. This is due to the recognition of important lateral facies variations, as well as tectonic repetitions of the sequences, as described in the present work.

Two litho-structural units can be described for the Rio Pardo Group, the first one occupying the northeastern part of the basin, and the second in the southwestern part of the basin, the limit between them being clearly marked by the Rio Pardo-Água Preta Inverse Fault, trending NW-SE and dipping southwesterly. The first unit is autochthonous, displaying open folds and slaty cleavage, but grading southwesterly into large overturned folds with axial plane schistosity. This unit is monophasic and exhibits tectonic shortening of $15 \%$. The second unit is polyphasic and exhibits large folds with a northeastern vergence. Tectonic shortening of about $40 \%$ is produced mainly during the second and most important deformational phase. A third folding phase is locally conspicuous, displays a E-NE vergence, and increases in intensity towards the western border of the basin.

Regional metamorphism of the Rio Pardo Group is associated with the first phase of folding, 
and can be described as an intermediate Barrowian type in the chlorite and biotite zone.

A lower limit to the depositional age of the Rio Pardo Group is given by some radiometric determinations on basic dikes intruding the basement, which yielded apparent K-Ar ages about $1.100 \mathrm{Ma}$. The upper limit is set by $\mathrm{Rb}-\mathrm{Sr}$ ages of about $550 \mathrm{Ma}$, which correspond to the late tectonic phases of the Brasiliano Orogeny.

On the basis of structural pattern and absence of magmatism, the Rio Pardo Group can be classified as a cratonic cover, whose sedimentation occurred during a paraplatformal stage of the São Francisco Craton. It was affected by intense tectonism due to the development of the Araçuai Fold Belt, at the southeastern border of the craton. Moreover, the Rio Pardo-Água Preta Fault is here assumed as the tectonic boundary between the São Francisco Craton and the Araçuai Folded Belt, which means that, in the author's opinion, the southwestern part of the Rio Pardo Group, tectonized and regionally metamorphosed, really belongs to the Araçuar Belt of the Brasiliano Orogeny.

In the context of the São Francisco Craton, the Salobro Formation can be correlated, on the basis of lithologic similarities, with the Bebedouro Formation. The both began upon an important disconformity, probably due to a regional epeirogenes of the craton in the Late Proterozoic. The Panelinha and Itaimbe Formations of the Rio Pardo Group are here considered as stratigraphically equivalent to the upper Chapada Diamantina Group and upper Espinhaço Supergroup. The Rio Pardo Group can also be correlated either with the Sanksikwa and Haut Shiloango Groups of the West Congo Belt (Africa), or with the upper part of the Mayombe Supergroup and the lower unit of the West Congolian Supergroup.

\section{LAZZARI, Maria de Lourdes}

O metabasito de Pirapora do Bom Jesus, SP. 27 de julho. 96p. 1 vol. Orientador: José Moacyr Vianna Coutinho.

Resumo: Em Pirapora de Bom Jesus, SP, um corpo de rocha metabasítica ocorre em meio a metarenitos finos e, subordinadamente, metarcósio, metagrauvaca, filitos, dolomito, quartzito e itabirito.

As rochas metabasíticas são compostas essencialmente de anfibólios e plagioclásios, tendo como acessórios: epídoto, clorita e titanita. O anfibólio tem composição actinolítica e o plagioclásio, albítica.

São comparáveis quimicamente a outros metabasitos descritos na literatura, possuindo afinidade com basaltos toléiticos e de fundo oceânico.

Grande parte das .exposições de metabasito alterado nas colinas margeando o Rio Tietê exibem estruturas de pillow lava com almofadas pouco deformadas ou deslocadas de sua posição original, com o pedúnculo para baixo e a superfície convexa para cima.

Pelo comportamento químico dos minerais é possível concluir que os metabasitos se formaram em condições ajustadas à fácies xisto verde de TURNER (1968). A temperatura metamórfica nestas rochas teve variação limitada ao intervalo de 300 a $450^{\circ} \mathrm{C}$.

Abstract: A metabasitic rock body occurs intercalated to fine grained meta-arenites and, subordinately, meta-arkoses, metagreywackes, phyllites, dolomites, quartzites and itabirites in Pirapora do Bom Jesus, São Paulo State.

These metabasitic rocks are made up essentially by amphiboles and plagioclases, with 
epidote, chlorite and titanite as accessories. The amphibole has actinolitic, and the plagioclase, albitic compositions.

They are chemically comparable to other metabasites quoted in the literature, sharing characteristics with tholeiitic and ocean-floor basalts.

A great part of the altered metabasite exposures on the hillsides of the Tietê River banks display pillow structures with pillows only slightly deformed or dislocated from their original position, with their cusps pointing downwards, and their convex surface upwards.

The chemical behaviour of the minerals permits to conclude that the metabasites underwent metamorphism under conditions comparable to those of the greenschist facies of TURNER (1968). The temperature of metamorphism in these rocks had a limited variation in the 300 to $450^{\circ} \mathrm{C}$ interval.

\section{LOPES, Luciana Maria}

A evolução mineralógica, micromorfológica e química da bauxita e materiais correlatos da região a nordeste de Mirat, Minas Gerais. 23 de dezembro. 120p. 1 vol. Orientador: Adilson Carvalho.

Resumo: Os depósitos de bauxita da região de Miraí, MG, inserem-se entre aqueles que compõem um extenso cinturão aluminoso, que se inicia a sudoeste de Cataguases, Minas Gerais, estendendo-se até o nordeste deste Estado.

Os depósitos da faixa em questão constituem-se na primeira grande reserva brasileira de minério de alumínio desenvolvida sobre uma variedade de rochas metamórficas de alto grau (gnaisses e granulitos) variadamente cataclasadas (pré-cambrianas integrantes do Complexo Juiz de Fora).

Desde que a área pesquisada insere-se numa faixa nordeste de morros meia-laranja em cujos topos ocorre sistematicamente a bauxita, decidiu-se pelo estudo em um morro-tipo, representativo de seu padrão de ocorrência. No morro escolhido, optou-se pelo estudo de topossequências, desde que ao longo das mesmas tem-se demonstrado haver diferenciação nos fenômenos de alteração.

A bauxita apresenta-se como fragmentos róseos e avermelhados em sua maioria com estrutura gnáissica conservada, com densidade aparente variando de 1,6 a 2,0 e teores médios de $\mathrm{Al}_{2} \mathrm{O}_{3}$ da ordem de $42 \%$.

Sua mineralogia consta essencialmente de gibbsita e goethita, hematita e quantidades subordinadas de quartzo e caolinita.

Tanto na bauxita isalterítica como na isalterita estéril que prevalece nas encostas e baixadas, a estrutura gnáissica foi conservada. São notáveis as pseudomorfoses de gibbsita a partir dos feldspatos, de goethita a partir dos piroxênios e anfibólios e de caolinita derivada da biotita. Na bauxita, a caolinita sofreu uma dessilicificação, ao passo que o quartzo foi em parte dissolvido, o que elevou relativamente os teores de aluminio. Tanto a bauxita isalterítica como a isalterita formaram-se por alitização direta da rocha.

Constatou-se, na bauxita, a presença de uma camada na qual houve um expressivo aporte de material iluvionar, propiciando a formação de numerosos cutans do tipo ferri-argilas. Em tal nível houve uma perda das estruturas gerando a bauxita aloterítica, que não demonstra mais sua derivação gnáissica, tendo se formado por alitização indireta da rocha.

A formação da bauxita deu-se de forma sistemática nos topos e encostas superiores dos morros meia-laranja que compõe o relevo da área. Para que tal ocorresse a topografia e, conseqüentemente, a drenagem, desempenharam papel decisivo, desde que suplantaram a variada natureza 
das rochas parentais bandadas e foliadas, convertendo-as num produto final com teores similares de $\mathrm{Al}_{2} \mathrm{O}_{3}$. No entanto, o caráter máfico de determinados níveis parentais conferiu, à bauxita deles derivada, teores médios de $\mathrm{Fe}_{2} \mathrm{O}_{3}$ da ordem de $18 \%$.

Assim sendo, nos topos e encostas superiores formaram-se crostas aluminosas e aluminoferruginosas (minério), que chegam a ter $8 \mathrm{~m}$ de espessura, ao passo que nas encostas e baixadas prevalece material mais argiloso e/ou areno-argiloso (estéril).

$\mathrm{Na}$ evolução da bauxita no tempo as condições de alteração variaram, gerando perfis polifásicos com bauxita isalterítica (de estrutura conservada) e aloterítica (sem preservação das estruturas). A tendência da fase atual de alteração é o da monossialitização.

Ressalta-se a interessante associação da área bauxitizada com movimentos tectônicos recentes (Tenciários) e com a ulterior incisão dos rios Pomba e Muriaé que, dissecando seus cursos, erodiram parte da bauxita, ausente nos vales dos rios supramencionados. Afastando-se dos mesmos, ressurgem as áreas bauxitizadas.

Abstract: The bawxite deposits in the Miraí region, Minas Gerais, Brazil, are among those that constitute a long aluminum belt beginning southwest of Cataguases and stretching into the northeast of Minas Gerais State.

The above mentioned deposits constitute Brazil's major reserve of aluminum ore evolved from a variety of pre-Cambrian cataclased high grade metamorphic rocks (gneiss and granulites) with integrate the Juiz de Fora Complex.

The study area is located in a northeastern strip of half-oranges hills which are systematically topped by bauxite. It was therefore decided to study a model hill representative of this pattern of occurrence.

Toposequences have been studied along the selected hill, since generally evidences in different alteration phenomena have been shown following differences in topography.

The bauxite appears in the form of rose-colored or reddish fragments generally preserving gneissic structure, with bulk density between 1.6 to 2.0 and average content of $\mathrm{Al}_{2} \mathrm{O}_{3}$ around $42 \%$.

The mineralogy of bauxite consists essentially of gibbsite and goethite, hematite and subordinate quantities of quartz and kaolinite.

Gneissic structure has been preserved both in isalterite bawxite and in the sterile isalteritic which predominates along hillsides.

The pseudomorphic textures of gibbsite from feldspars, of goethite from pyroxenes and amphiboles, and of kaolinite from biotite are remarkable. In bawxite, kaolinite suffered desilification, while quartz was partly dissolved, resulting in relatively high aluminum content. Both isalteritic bauxite and isalterite were formed through direct allitization of the rock.

In the bauxite has been detected a layer where a considerable quantity of illuvial material has been accumulated, causing the formation of numerous ferri-argillic cutans. In this layer, the structure has been destroyed generating aloteric bauxite, which no longer shows his gneissic derivation, having been formed by indirect allitization of the rock.

The formation of bauxite took place systematically on the tops and upper slopes of the halforanges hills that make up the local relief. In order for that to have occurred, topography and, consequently, drainage have played a decisive rele, since they have supplanted the diverse nature of banded and foliated parent rocks, converting them into a final product with similar $\mathrm{Al}_{2} \mathrm{O}_{3}$ content. However, the mafic character of certain parent levels caused the derived bawxite to present average $\mathrm{Fe}_{2} \mathrm{O}_{3}$ content around $18 \%$. 
Any how, on tops and upper-slopes aluminous and alumino-ferruginous (ore) crusts have formed with a thickness of as much as $\mathbf{8}$ meters, while on slopes and on lower areas more argillous and/or areno-argillous (sterile) material prevails.

During the evolution of bauxite conditions of alteration have changed, forming polyphasic profiles with isalteritic bauxite (with preserved structure) and aloteritic bauxite (without structure preservation). The present alteration phase tends towards monossialitization.

It is pointed out the interesting association of the bauxitized area with recent (Tertiary) tectonic movements.

The later incision of Pomba and Muriae rivers eroded away part of the bauxite which any way reappears along the valleys sides.

NEGRÃO, Francisco Inácio

Caracterização hidrogeoquímica e vulnerabilidade do sistema hidrogeológico cárstico da região de Irecê, Bahia. 06 novembro. 86p. 1 vol. Orientador: Mária Szikszay.

Resumo: No presente trabalho são utilizados os dados de 160 análises químicas de águas de poşos, mapa geológico e superfície potenciométrica do sistema hidrogeológico cárstico da região de Irecê, para investigar os mecanismos de evolução da composição química da água subterrânea e delimitar as áreas de maior ou menor grau de vulnerabilidade do aqüífero aos poluentes e contaminantes introduzidos no sistema pela atividade humana. Os resultados obtidos mostraram que essas águas são originárias da infiltração, tanto da precipitação direta sobre os terrenos Calcários Bambuí, quanto indireta através dos Quartzitos Chapada Diamantina. A evolução hidroquímica no carste mostrou-se caracterizada pela circulação muito rápida, trajetos curtos entre as zonas de recarga e descarga, conseqüente da distribuição local de fluxos. Tais fatos são reforçados pela evolução hidroquímica incompleta da água subterrânea em seu percurso, pois apenas dois tipos predominantes de água, as bicarbonatadas-cálcicas e as cloro-sulfatadas cálcicas se alteram nas várias zonas de fluxos locais, restritas ao sistema cárstico da área. Por outro lado as águas da zona de contato entre os calcários e os quartzitos têm caráter misto promovido pelo aporte de águas quartzíticas doces. O mapa de vulnerabilidade do aqüffero mostra os limites das zonas a serem prioritariamente protegidas e/ou monitoradas na área de estudo, além dos indícios de poluição do sistema por nitratos.

Abstract: This paper presents the results of a study on ground water chemistry. For this reason samples from 160 wells, geological maps, potentialmetric surface maps of the karstic hydrogeologic system of Irecê region were used. The aims of the investigation were to study the evolution of the chemical composition of the groundwater and to establish the aquifer vulnerability caused by the environmental impact of the human activity.

This research has confirmed that the origins of this ground water are from direct infiltration of rainfall over the Bambuí limestone and indirectly from the Chapada Diamantina quartzites. The hydrogeochemical evolution of karstic terrains was marked by rapid circulation flows and short pathways between its recharge and discharge zones due to local waterflow distribution. These observations are confirmed by the observed hydrochemical evolution of ground water in flowpath, where two ground- water types have been identified so far in the studied area: the calcium bicarbonate and calcium-chlorine-sulfate 
types. On the other hand, ground waters from the contact zone between limestones and quartzites have their hybrid character promoted by mixing with quartzitic fresh waters. The vulnerability map of the aquifer shows the limits of the zones to be monitored and protected against the effects of the advanced agricultural and urban development of the region.

PERINOTTO, José Alexandre de Jesus

Análise estratigráfica da seqüência portadora de carvão na região de Cerquilho, $S P$. 21 de dezembro. 76p. 1 vol. Orientador: Oscar Rösler.

Resumo: A presente dissertação tem por objetivo propor uma evolução paleogeográfica para o conjunto sedimentar portador de carvão na região de Cerquilho (SP), bem como a sua posição estratigráfica no âmbito do Grupo Tubarão.

O desenvolvimento dos trabalhos foi possível graças ao grande número de dados oriundos do Projeto Carvão de Cerquilho, realizado através de um convênio entre a Universidade Estadual Paulista (UNESP)-Campus de Rio Claro e a Companhia Energética de São Paulo (CESP).

A metodologia utilizada foi a descrição de testemunhos de sondagens rotativas, poços rasos (cacimbas) e seções de superfície. Algumas sondagens foram perfiladas, e dos perfis realizados, o de Raios Gama mostrou-se bastante útil nas correlações.

Foram estabelecidas onze diferentes fácies para a região como um todo, distinguindo-se três áreas com conjuntos faciológicos próprios: Aliança-Taquaral, Mato Seco e Itapema.

Através da análise faciológica e diversas correlações pôde ser estabelecido um quadro evolutivo da paleogeografia da região que mostra para a área Aliança-Taquaral um lobo deltaico ativo com as fácies de prodelta, frente deltaica e planície deltaica, onde houve condições de formação de turfeiras; para a região de Mato Seco prevalecia uma sedimentação costeira com barras de barreira confinando lagunas interiores, também gerando acumulações carbonosas; em Itapema postula-se a existência de um provável embaiamento, lateral ao lobo de Aliança-Taquaral, onde o predomínio de processos de maré imprimiu a característica lenticularidade das camadas nesta área, onde não existe acumulação carbonosa como nas anteriores. Com o nível do mar ascendente, os depósitos mencionados são encobertos e parcialmente retrabalhados, gerando depósitos de praias e planícies de maré, e, finalmente, com o domínio do avanço transgressivo, imperam condições plataformais que afogam toda a seqüência.

Do ponto de vista litoestratigráfico, com base não só nos dados obtidos, mas também em uma análise regional que vem sendo realizada por FÚLFARO et al. (em prep.), optou-se por designar o conjunto sedimentar estudado como Formaçẩo Tietê (no sentido de FÚlFARO et al., 1984). Esta unidade posiciona-se concordantemente entre o topo do Subgrupo Itararé e a base Formação Tatuí, e é correlacionável à Formação Rio Bonito dos estados do sul.

Abstract: The purpose of this dissertation is to propose a paleogeographic evolution for the coal bearing sedimentary sequence from Cerquilho region, São Paulo State, as well as its stratigraphic position within the Tubarão Group, Paraná Basin.

The development of this work was made possible by large amount of data originated by Cerquilho Coal Project, a covenant between Universidade Estadual Paulista (UNESP)-Campus de Rio Claro and Companhia Energética de São Paulo (CESP). 
Faciological description of rotative drill cores, shallow wells and surface sections constituted the applied methodology. Among the logged drill holes, Gamma Ray log proved to be very useful in correlations.

Eleven distinct facies were identified in the region as a whole, in which three different areas with unique facies association were distinguished: Aliança-Taquaral, Mato Seco and Itapema.

A picture of regional paleogeographic evolution was drawn through faciological analysis and several correlations: an active deltaic lobe for Aliança-Taquaral area, with prodelta, delta front and delta plain facies, where the formation of peat occurred; coastal sedimentation predominated in the Mato Seco area, with barriers bars closing inner lagoons, also generating carbonaceous accumulations; a probable embayment at the side of Aliança-Taquaral deltaic lobe is postulated for the Itapema area, in which predominant tidal processes imposed bed lenticularity characteristics, without carbonaceous accumulations comparables to the others areas. With ascending sea level, these deposits were covered and partially reworked, forming beaches and tidal flats. Finally, with continued transgression, shelf conditions drowned the whole sequence.

The decision of naming this sedimentary sequence as Tietê Formation (in sense of FULFARO et al., 1984) was based, from a lithostratigraphic standpoint, not only on obtained data, but also on a regional analysis by FÚLFARO et al.(in prep.). The Tietê Formation lies conformably over the Itararé Subgroup and below Tatú Formation and it is correlative with the Rio Bonito Formation of the southern states.

\section{SANTOS, Juarez Fontana dos}

Tipologia e gênese do depósito de tungstênio de Pedra Preta, PA. 18 de maio. 100p. 1 vol. Orientador: Evaristo Ribeiro Filho.

Resumo: A jazida de tungstênio de Pedra Preta, localizada na região amazônica, é constituída por filões de quartzo e wolframita encaixados em rochas metamórficas do Proterozoico Inferior, associados a uma intrusão granítica.

Ao par da integração dos dados geologicos coletados durante a execução dos trabalhos de avaliação do jazimento, o autor realizou estudos específicos visando definir a mineralização, o condicionamento estrutural, a caracterização físico-química, bem como os parâmetros condicionantes de sua gênese.

As interpretações formuladas relacionam a metalização aos fenômenos de alteração hidrotermal de caráter metassomático (greisenização), que afetaram indistintamente a cúpula granítica e as rochas circundantes.

A atividade hidrotermal que afetou a intrusão granítica evoluiu desde uma fase de feldspatização potássica (microclinização), passando por uma fase intermediária de feldspatização sódica (albitização), e culminado com o desenvolvimento da greisenização s.s., responsável pela ocorrência dos eventos mineralizadores.

A paragênese mineral do minério é produto da evolução sucessiva de três estádios: o estádio precoce, caracterizado pela deposição dos óxidos (wolframita e hematita); o estádio intermediário, no qual depositaram-se os sulfetos ( $\mathrm{Fe}, \mathrm{Cu}, \mathrm{Mo}, \mathrm{Bi}, \mathrm{Zn}$ ) e o estádio tardio, com a deposição dos carbonatos.

A jazida de Pedra-Preta, por suas características, é classificada como um depósito de 
tungstênio do tipo hidrotermal precoce (alta temperatura), segundo o conceito de HOSKING (1982), vinculada espacial e geneticamente à Intrusão Granítica da Musa.

O deposito de Pedra Preta é comparado aos jazimentos filonianos a quartzo-wolframita que ocorrem no Distrito de Xihuashan, na Província de Jiangxi da República Popular da China.

Abstract: Tungsten mineralization at Pedra Preta, occurs in a quartz vein field emplaced in Lower Proterozoic metamorphosed supracrustal rocks, situated in the Amazon region. The mineralization and attendant hydrothermal alteration are spatially and temporally related to an allochthonous intrusive granite.

The petrographic, mineralogic and geochemical studies allow some insight on the genesis and evolution of the mineralization.

The ore assemblage is dominated by wolframite with minor sulphides $(\mathrm{Fe}, \mathrm{Cu}, \mathrm{Mo}, \mathrm{Bi}, \mathrm{Zn})$. Quartz muscovite, topaz, fluorite and carbonate are the principal gangue minerals.

The paragenetic sequence for the Pedra Preta mineralization can be divided in three main stages. The early stage, defined by the concomitant deposition of quartz, wolframite and hematite. The intermediate stage characterized by the precipitation of sulphides and the late stage identified by carbonate deposition.

The tungsten mineralization is a product of a typical exogreisen cupola hydrothermal system associated with the emplacement of the Musa Granite.

The Pedra Preta deposit is classified as an early hydrothermal tungsten deposit, HOSKING (1982), and considered quite similar to the quartz-wolframite lode deposits of Xihuashan mining district in the Jiangxi province, R.P.China.

\section{SANTOS, Rosa Penha dos}

Associaçōes de foramintferos e tecamebas da Foz do Rio Itajai-Açu, SC. Relacionadas com os subambientes de deposição. 09 de setembro. 102p. 1 vol. Orientador: Setembrino Petri.

Resumo: A presente dissertação trata de um levantamento da distribuição de foraminíferos e tecamebas atuais, no baixo Rio Itajaí-Açu, Estado de Santa Catarina, até a região marinha sob a influência deste rio, com o objetivo de se estabelecer um padrão de distribuição destes organismos e sua possível utilização na interpretação da hidrodinâmica das correntes fluviais e costeiras, principalmente as de maré.

Foi possível, deste modo, distinguir os seguintes subambientes: a) marinho; b) estuarino; c) Saco de Fazenda e molhes fluviạis; e, d) fluvial. No subambiente fluvial foi possível distinguir áreas de maior influência marinha e áreas de menor influência marinha, possivelmente ligadas às direções das correntes fluviais e de maré.

A distribuição das associações dos organismos em pauta foi comparada com a distribuição nas regiões fluviomarinhas da Foz do Rio Doce e do Sistema Mariricu-S.Mateus, no Estado do Espírito Santo. Ressaltou-se desta comparação, que os três sistemas fluviomarinhos são diferentes entre si, diferenças estas explicadas pelo maior ou menor grau de penetração das correntes de maré rio adentro.

Abstract: The purpose of this research was to establish the pattern of distribution of living foraminifers and thecamoebians along the lower Itajaí-Açu river and adjacent ocean in the Santa Catarina State, Brazil, and to interpret this pattern in the light of the interplay of river and tidal currents. 
The distribution of these organisms allowed the recognition of the following subenvironments: a) marine; b) estuarine; c) "Saco da Fazenda" and "molhes"; and, d) fluviatile. Areas of marked marine influence and areas of marked river influence were detected within the fluviatile subenvironment, of river and tidal corrents reflecting the interplay.

Comparisons with similar mixed fluviatile and marine patterns of these organisms in the Espirito Santo State, Brazil, at the mouths of the Doce River and the Mariricu-S.Mateus river system revealed significant differences between these river systems as the result of differing penetration of marine waters along the river channels.

XAVIER, Roberto Perez

Estudos de inclusões fluidas na Mina de Ouro Fazenda Brasileiro "Greenstone Belt" do Rio Itapicuru, Bahia. 01 de junho. 142p. 1 vol. Orientador: José Vicente Valarelli.

Resumo: Na porção nordeste do Cráton do São Francisco, no Estado da Bahia, foi definido um grupo de rochas supracrustais vulcano-sedimentares fortemente deformadas e intrudidas por domos granitognáissicos, que vieram a caracterizar o "Greenstone Belt" do Rio Itapicuru, de provável idade arqueana ou proterozóica inferior.

A seqüência vulcano-sedimentar compreende extensos derrames de rochas basálticas e complexos lenticulares localizados, constituídos por lavas e rochas piroclásticas intermediárias a ácidas. A sedimentação química e detrítica imatura se faz presente ao longo de toda seqüência associada ao vulcanismo máfico, intercalada e mesclada ao vulcanismo félsico e formando cobertura. Esta seqüência vulcano-sedimentar encontra-se metamorfizada regionalmente na fácies xisto verde e anfibolito baixo.

As principais mineralizações auriferos estão restritas à parte sul deste terreno vulcanosedimentar, encontrando-se ao longo de um trend de cisalhamento de direção geral E-W e com mais $9,5 \mathrm{~km}$ de extensão, denominado Faixa Weber, onde se localiza a Mina Fazenda Brasileiro. As mineralizações pertencem à Seqüência Fazenda Brasileiro e hospedam-se em um quartzo-clorita xisto portador de magnetita, denominado "xisto magnético", e corpos lenticulares de uma rocha brechada, de composição essencialmente quartzo-feldspática (brecha quartzo-feldspática). O ouro aparece nestas rochas no seu estado nativo associado a sulfetos, principalmente arsenopirita e pirita, e secundariamente disseminado em veios de quartzo de colocação tardia.

Os estudos de inclusões fluidas se concentraram ao longo das zonas mineralizadas da Mina Fazenda Brasileiro, especialmențe na brecha quartzo-feldspática e veios de quartzo, onde tanto inclusões consideradas primárias como secundárias foram selecionadas, descritas e submetidas a estudos de microtermometria e analisadas por espectroscopia Raman.

Os resultados dos estudos de microtermometria e espectroscopia Raman em inclusões fluidas carbônicas e aquocarbônicas permitiram definir os fluidos mineralizantes como soluções quentes (> $\left.400^{\circ} \mathrm{C}\right)$, de densidade relativamente alta $\left(0,85-0,90 \mathrm{~g} / \mathrm{cm}^{3}\right)$, inicialmente compostas por $\mathrm{CO}_{2}(89,7-85,4$ moles\%) e pequenas quantidades de $\mathrm{CH}_{4}$ e $\mathrm{N}_{2}$, que evoluem com o abaixamento da temperatura (250$\left.300^{\circ} \mathrm{C}\right)$ e ascensão crustal para soluções que tornam-se gradativamente mais aquosas $(40$ a 62,5 moles\% de $\mathrm{H}_{2} \mathrm{O}$ ) e de baixa salinidade ( $<10$ eq. $\% \mathrm{NaCl}$ ).

Através das isócoras dos fluidos das inclusões carbônicas e aquocarbônicas, juntamente com dados da paragênese mineral sugere-se a existência de pelo menos dois períodos de deposição do ouro: (1) 
$380-491^{\circ} \mathrm{C}$ e 2,2-3,2 kb na brecha quartzo-feldspática e veio de quartzo com arsenopirita e pirita; e, (2) 270 $300^{\circ} \mathrm{C}$ e 1,2-1,4 kb no veio de quartzo maciço.

Baseado em estudos experimentais da solubilidade de complexos auríferos, nas características químicas dos fluidos mineralizantes, na paragênese de minério e na razão $\mathrm{Au} / \mathrm{Ag}$, assume-se que o ouro deve ter sido transportado como tio-complexos do tipo $\mathrm{Au}(\mathrm{HS})_{2} / \mathrm{HAu}(\mathrm{HS})_{2}^{\circ}$ e $\mathrm{Au}_{2}(\mathrm{HS})_{2} \mathrm{~S}^{-2}$ por soluçóes redutoras (razão $\mathrm{SH}_{2} \mathrm{~S} / \mathrm{SSO}_{4}$ alta) e com pH em torno da neutralidade ou levemente alcalino.

Nos estágios mineralizantes iniciais, condições para a precipitação de ouro foram atingidas, devido às reações fluido/rocha, que levaram ao decréscimo na atividade de $\mathrm{S}^{-2}$ com a precipitação dos sulfetos metálicos (arsenopirita, pirita, pirrotita, etc). Nos estágios de colocação dos veios de quartzo tardios acredita-se que a deposição do ouro tenha ocorrido pela introdução de $\mathrm{H}_{2} \mathrm{O}$ no sistema, causando a diluição de $\mathrm{CO}_{2}$ diminuição do $\mathrm{pH}$, oxidação e conseqüente desestabilização dos complexos transportadores deste metal.

A origem metamórfica destes fluidos mineralizantes é também indicada pelo estudo de inclusões fluidas, entendendo-se que possam ser derivados a partir de processos de devolatização das seqüências mais basais do greenstone belt, capaz de produzir fluidos carbônicos e aquocarbônicos de baixa salinidade, que posteriormente migram através de sítios estruturais favoráveis causam fraturamento hidráulico e depositam seu conteúdo metálico.

Finalmente, tornou-se aparente que os resultados e conclusões obtidas neste estudo estão de acordo com trablahos de mesma natureza realizados em diversos depósitos de ouro em terrenos granitogreenstone arqueanos.

Abstract: In the northeast portion of the São francisco Craton, in the Bahia State, a group of highly folded supracrustal rocks surrounded by oval granite-gneiss domes was defined and later know as the Rio Itapicuru Greenstone Belt, of probable Archaean or Porterozioic age.

The vulcano-sedimentary sequence of this belt comprises large basaltic flows togeteher with lenses of lavas and pyroclastic rocks of intermediate to felsic composition. Clastic and minor chemical sediments occur throughout the whole sequence and in the upper part they form thick individualized horizons. This whole sequence was regionally affected by a metamorphism of greenschist to lower amphibolite facies.

In this region the main gold mineralizations occur in the southern part of the Rio Itapicuru Greenstone Belt, being restricted to a shear zone, called Faixa Weber, which extends for over $9.5 \mathrm{~km}$ along its E-W strike, and in which the Fazenda Brasileiro Mine is situated. The mineralizations are enclosed in the Fazenda Brasileiro Sequence and are hosted by a magnetite-bearing quartz- chlorite schist (magnetic schist), as well as discontinuous and strongly deformed lenticular-shaped bodies composed solely of quartz and feldspar (quartz feldsphatic breccia). Gold occurs in its native state associated with sulphides, notably arsenopyrite and pyrite, and secondarily disseminated in late quartz veins.

Fluid inclusion studies were carried out on mineralized samples (quartz feldsphatic breccia and quartz veins) of the Fazenda Brasileiro Mine with the aim of selecting and describing primary and secondary inclusions in order to analyse them by microthermometry and Raman spectroscopy.

Based on the microthermometric and Raman spectroscopic data of carbonic and $\mathrm{H}_{2} \mathrm{O}-\mathrm{CO}_{2}$ inclusions, it was possible to define the mineralizing fluids as relatively dense $\left(0.85-0.95 \mathrm{~g} / \mathrm{cm}^{3}\right.$ ) and hot (> $400^{\circ} \mathrm{C}$ ) solutions composed essentially of $\mathrm{CO}_{2}(89.7-85.4 \mathrm{~mol} \%)$ and minor amounts of $\mathrm{CH}_{4}$ and $\mathrm{N}_{2}$, which gradually evolved to more aqueous fluids $\left(40\right.$ to $\left.62.5 \mathrm{~mol} \% \mathrm{H}_{2} \mathrm{O}\right)$ of low salinity $(<10 \mathrm{wt} \% \mathrm{NaCl})$ at lower temperatures $\left(250-300^{\circ} \mathrm{C}\right)$ and higher crustal levels. 
The isochores of the carbonic and $\mathrm{H}_{2} \mathrm{O}-\mathrm{CO}_{2}$ fluids, the temperature of total homogenization and mineral equilibrium in the ore paragenesis, point to at least two periods of gold deposition: (1) 380 $491^{\circ} \mathrm{C}$ and 2.2-3.2 kb in the quartz feldsphatic and arsenopyrite - pyrite quartz veins; (2) $270-300^{\circ} \mathrm{C}$ and $1.2-1.4 \mathrm{~kb}$ in the massive quartz vein.

Based on experimental work in the solubility of gold complexes, chemical characteristics of mineralizing fluids, ore paragenesis and $\mathrm{Au} / \mathrm{Ag}$ ratio, it was possible to speculate that gold could be transported by reducing (high $\mathrm{K}_{2} \mathrm{~S} / \mathrm{SSO}_{4}$ ), slightly neutral to alkaline solutions, as thiocomplexes such as $\mathrm{Au}(\mathrm{HS})_{2}, \mathrm{HAu}(\mathrm{HS})_{2}^{0}$ and $\mathrm{Au}_{2}(\mathrm{HS})_{2} \mathrm{~S}^{-2}$.

In the earliest stage of mineralization, conditions of gold deposition were probably attained due to fluid/rock reactions which led to a decrease in the activity of $\mathrm{s}^{-2}$ by precipitating sulphides (arsenopyrite, pyrite, pyrrhotite etc.).

The predominance of the $\mathrm{H}_{2} \mathrm{O}$ regime over the $\mathrm{CO}_{2}$ regime at higher crustal levels might have been the cause of $\mathrm{CO}_{2}$, dilution, decrease in $\mathrm{pH}$ and oxidation and, as a consequence, the precipitation of gold.

The fluid inclusion data also suggest a metamorphic origin for the mineralizing fluids, most likely through the devolatilization of the basal sequences of the volcano-sedimentary pile. The devolatilization process would be able to produce low salinity, $\mathrm{H}_{2} \mathrm{O}-\mathrm{CO}_{2}$ fluids which would later migrate through favorable structural sites and deposits their metal content.

Comparing the results of the present study, it is apparent that the data obtained and conclusions reached agree with work of the same nature carried out on other gold deposits of similar granite-greenstone terrains.

\section{M-36}

ZANARDO, Antenor

Análise petrográfica e microestrutural das rochas da Folha de Aguas de Lindóia. 08 de julho. 270p. 1 vol. Orientador: Marco Aurélio Farias de Oliveira.

Resumo: A área estudada, Folha de Águas de Lindóia, é limitada pelos meridianos $46^{\circ} 30^{\prime}$ e $46^{\circ} 45^{\circ} \mathrm{WG}$, pelos paralelos $22^{\circ} 15^{\prime}$ e $22^{\circ} 30^{\prime} \mathrm{S}$, e foi mapeada na escala 1:50.000 objetivando-se obter um melhor entendimento da evolução geológica e a separação de rochas pertencentes a infra- e supraestrutura, através de dados cartográficos, petrográficos, estruturais, microestruturais e de outros dados existentes na literatura.

Nessa folha aparecem rochas sedimentares associadas às drenagens e rampas de colívio, sedimentos anquimetamorfizados (Formação Eleutério), rochas magmáticas de composição granítica a granodiorítica mais ou menos gnaissificada e/ou milonitizada (Grupo Pinhal), pegmatitos, aplitos e raros diques de diabásio e microssienito, rochas cataclásticas (milonitos e cataclasitos) e rochas metamórficas de grau médio a alto. Dentro desse último grupo foram caracterizados migmatitos e gnaisses de composição granodiorítica a trondhjemítica (unidade basal infracrustal); migmatitos e gnaisses, de composição granítica a granodiorítica (supracrustal) e rochas indubitavelmente metassedimentares com intercalações em gnaisses quartzo feldspáticos e/ou migmatitos (unidade superior supracrustal).

As grandes estruturas da áreas são desenhadas por uma foliação paralela a um bandamento tectônico e/ou composicional formando complexos padrões de "redobramento", braquiantiformais e sinformais, domos, lentes, boudins e macrólitos. Essa estruturação e a lineação mineral e de estiramento 
são afetadas por duas grandes zonas de cisalhamento denominadas de Jacutinga e Monte Sião e por outras de menor expressão.

A nível de afloramento foram observadas diferentes estruturas tais como dobras, lineaça mineral e de estiramento, juntas, veios de quartzo, aplito e pegmatito, shear zones, pods, macrólitos, boudins, pinch and swell e foliações $S$ e $C$. A nível microsc6pico além de examinar melhor as estruturas referidas acima, foram realizadas medidas de orientação de eixo optico e normais à forma 001 das micas, além de outros estudos texturais e microestruturais, visando ordenar no tempo as transformações mineralogicas e paragenéticas.

Os estudos estruturais e microestruturais permitiram reconhecer com segurança um ciclo deformacional dominantemente dúctil, e mostrou evidências da existência de um ciclo deformacional anterior, eminentemente ductil, nas rochas aqui caracterizadas como infra e crustais. Superposta à deformação mencionada acima, pode ser notado apenas mais um ciclo ou fase de deformação frágil a frágildúctil. A deformação dúctil é de caráter progressivo, em regime dominantemente não coaxial, com transporte de massa inicialmente para NW e, posterior rotação das estruturas e lineações para N-S e NESW, contemporaneamente a instalação das zonas de cisalhamento dúctil de alto ângulo, denominadas de zonas de falhas de Jacutinga e Monte Sião. Com base nessas observações coloca-se em dúvida a separação entre unidades infracrustais e supracrustais.

O exame das paragêneses permitiu estabelecer pelo menos dois ciclos ou fases nítidas de metamorfismo para as rochas supracrustais e possivelmente três para a infra-estrutura. O metamorfismo de maior intensidade distribui-se de maneira homogênea por toda área, exibindo evidências de metamorfismo progressivo do tipo barroviano $\left(650\right.$ a $700^{\circ} \mathrm{C}$ e $\left.7 \mathrm{~kb}\right)$ e um metamorfismo regressivo em condições de pressão mais baixa, sempre dentro da fácies anfibolito. O tiltimo ciclo ou fase atingiu a fácies xisto verde média e manifesta-se de maneira mais intensa nas zonas de cataclase, superpondo-se à paragêneses anteriores, com exceção dos metassedimentos da Formação Eleutério, onde é a única fase presente.

Com base nos dados levantados e existentes na literatura foi reconhecido um embasamento arqueano (Grupo Amparo) um conjunto supracrustal de idade transamazônica e as litologias do Eleutério de idade brasiliana. Foi proposto ainda, tentativamente, um modelo geodinâmico do tipo colisão continental para a estruturação do principal ciclo deformacional presente na área, assim como uma síntese da evolução geologica.

Abstract: This work discusses cartographic, petrographic, structural and microstructural features of the infracrustal and supracrustal lithologies of the Águas de Lindoia area.

Ankimetamorphic sediments, granitic and granodioritic foliated rocks and medium to high grade metamorphic types represent the more important described lithologies. Between the metamorphic types migmatites and trondhjemitic to granodioritic gneisses represent the infrastructure and metasediments associated with granitic gneisses represent the suprastructure.

As a very important structure in this area we have a foliation parallel to a tectonic or compositional banding, with complex antiformal and synformal features. This structure and the mineral lineation are affected by the Jacutinga and Monte Sião Shear Zones.

Two deformational ductil cycles are recognized in the infrastructure. The ductil deformation has a progressive character, with mass transportation to NW, with rotation of the lineation to NS- and NESW.

Paragenetic studies indicates progressive amphibolite facies metamorphism of the Barrowian type $\left(650^{\circ}-700^{\circ} \mathrm{C} ; 7 \mathrm{~kb}\right)$ and a retrogressive one in low pressure conditions. 
Based in the present studies an Archean basement (Amparo Group), a supracrustal sequence of Transamazonic age and a sedimentary group (Eleutério Formation) are recognized in this are. A geodynamic model, based in continental collision is here proposed to explain the chiefly deformational cycle now described.

\section{BERGMANN, Magda}

Caracterização estratignáfica e estrutural da seqüência vulcano-sedimentar do Grupo São Roque na região de Pirapora do Bom Jesus - Estado de São Paulo. 07 de julho. 166p. 1 vol. Orientador: Georg Robert Sadowski.

Resumo: Mapeamento geológico em escala 1:25.000, foi desenvolvido na região de Pirapora do Bom Jesus, São Paulo, na seqüência vulcano-sedimentar do Grupo São Roque de idade do Proterozóico Inferior a Médio.

O Grupo São Roque ocorre na região mapeada em uma grande estrutura sinclinorial (Sinclinório de Pirapora) que compreende rochas metamórficas do fácies xisto verde.

Através do levantamento de perfis estruturais de detalhe, com o emprego de estruturas geopetalicaş, foi efetuado o empilhamento dos litotipos da seqüência, e são propostas três unidades litoestratigraficas formais:

Formação Pirapora, basal ao Grupo São Roque, representada por uma pilha de rochas metavulcânicas e subvulcânicas de caráter básico tolefítico e rochas piroclásticas subordinadas, com um Membro Carbonático à calciofilitos e metadolomitos a estromatólitos; a Formação Estrada dos Romeiros, estratigraficamente superior, e em contato transicional com um Membro Arenoso na base e um Membro Pelítico no topo, e a Formação Boturuna, em contato brusco a transicional com o topo da formação precedente, comportando dois membros vulcânicos e dois membros arenosos.

São apresentados estratotipos com espessuras aproximadas, caracteres litologicos e correlações com outras unidades do Grupo São Roque, referidas pela bibliografia.

As relações entre as unidades litoestratigráficas, suas características litológicas e a distribuição das estruturas primárias torna possivel considerações sobre a paleogeografia e o ambiente de deposição da Sequeência São Roque, aqui associado a calhas rasas, do tipo nift intracontinental, com atividade vulcânica proeminente, nos primeiros estágios de sua evolução. A ocorrência de centros eruptivos do tipo vulcão é sugerida pela disposição de recifes carbonáticos, alguns a estromatólitos, circundando corpos metabasíticos estratificados de geometria oval.

São identificados na área do Sinclinório de Pirapora, cinco fases de dobramentos superimpostas, três delas sin- a tardimetamórficas e duas pós-metamórficas.

Uma articulação de dobras anticlinais recumbentes da segunda fase controla a geometria dos contatos entre as unidades litoestratigráficas, gerando intensa repetição aparente das mesmas. 0 
posicionamento dos estratos, em flanco normal, charneira ou flanco inverso destas estruturas, modifica a qualidade da foliação $S_{2}$ e sua relação com o acamamento e a foliação $S_{1}$.

A terceira fase de dobramentos é tardia ao metamorfismo, com dobramentos quase holomórficos aos traços axiais e eixos orientados de $\mathrm{E}$ a W, com mergulhos para NE e para W, e desenvolve clivagem plano axial espaçada. Duas fases pós-metamórficas, a fase do Sinclinório de Pirapora, com eixo mergulhante a N60-70E, e outra fase tardia em torno de NS-NNW, não são hierarquizadas.

Abstract: Geological mapping of the Pirapora Synclinorium on a scale of 1:25,000, in the region of Pirapora do Bom Jesus (eastern São Paulo State, Brazil), together with data obtained from geopetal indicators and regional structural profiling, has led to formal subdivision of the São Roque Group.

This group consists of a Lower to Middle Proterozoic volcano sedimentary sequence locally exhibiting greenschist facies metamorphism. Three formal lithostratigraphic units are here proposed, from the base to the top, as follows:

The Pirapora Formation is a basic volcanic to subvolcanic pile of tholeiitic character with subordinate pyroclastic rocks and a Carbonate Member characterized by calcio phyllites and stromatolite-bearing dolostones. The Estrada dos Romeiros Formation, gradationally above the Pirapora Formation, is represented by a basal Sandy Member, and capped by a Pelitic Member. The Boturuna Formation, exhibiting transitional to abrupt contacts with the underlying Estrada dos Romeiros Formation, is made up of two volcanic members and two sandy members. For each of these formations, stratotypes, lithologic characteristics and correlation with other stratigraphic units of the São Roque Group are presented.

The relationships observed among these lithostratigraphic units, their lithologies and the distribution of structures suggest that the deposition of the São Roque Sequence was associated with narrow, shallow, intracontinental rift basins, with volcanic activity prominent in the early stages.

The occurrence of eruptive centers (probably volcanoes) is evidenced by the association of oval-shaped stratified metabasites with stromatolitic fringe reef and unstable slope deposits.

Five phases of folding have been identified in the area of the Pirapora Synclinorium. The first and second were linked to metamorphic phenomena, the third was late metamorphic and the latest two postmetamorphic.

Second-phase recumbent anticlinal folding has lead to the repetition of lithostratigraphic units where as third-phase folding resulted in nearly holomorphic folds with E-ENE and W plunging hinges. This phase also generated a spaced axial plane cleavage. Regarding the two postmetamorphic phases of folding, one, with N60-70E plunging axes, was related to the formation of the Pirapora Synform while the other, trending NS-NNW, could not be structurally correlated.

CAMPOS, Heraldo Cavalheiro Navajas Sampaio

M-38

Contribuição ao estudo hidrogeoquímico do Grupo Bauru no Estado de São Paulo. 13 de janeiro. 158p. 1 vol. Orientador: Mária Szikszay.

Resumo: O Sistema Aqüifero Bauru representa uma das principais fontes de exploração de água subterrânea do Estado de São Paulo. É representado por sedimentos cretácicos do Grupo Bauru, de litologia variável, cobrindo uma área de $104.000 \mathrm{~km}^{2}$.

Em âmbito regional os objetivos deste estudo foram: a caracterização dos tipos 
hidrogeoquímicos e sua inter-relação; o zoneamento hidrogeoquímico com a diferenciação dos tipos químicos por unidades estratigráficas; o estudo da evolução da composição química das águas subterrâneas com a percolação do meio aqüf́fero; a determinação da qualidade das águas para os distintos usos e a determinação do potencial de ataque químico das águas subterrâneas aos equipamentos dos poços.

Foram utilizadas neste trabalho 336 análises químicas de águas subterrâneas. A interpretação dos dados hidroquímicos baseou-se no processamento dos resultados das análises químicas, no tratamento estatístico básico, em regressões lineares, em análises de tendências e em mapas de isovalores.

As águas subterrâneas apresentam, em geral, teores salinos muito baixos e pertencem a dois tipos químicos dominantes: o das águas bicarbonatadas cálcicas e o das águas bicarbonatadas calcomagnesianas. Os principais íons responsáveis pelo teor salino são o $\mathrm{HCO}_{3}^{-} \mathrm{Ca}^{2+}$ e $\mathrm{Mg}^{2+}$, oriundos da dissolução do cimento calćf́rero e dos argilominerais constituintes dos sedimentos. A tendência principal na evolução hidrogeoquímica regional destes íons é no sentido nordeste-sudeste. Quanto à aptidão das águas subterrâneas para os distintos usos, de um modo geral, atendem aos padrões exigidos; as águas são potencialmente incrustantes ou corrosivas ou potencialmente corrosivas.

Abstract: The Bauru Aquifer System stands for one of the main supplies of groundwater in the São Paulo State. It is represented by the cretaceous sediments of the Bauru Group with variable lithology, covering an area of $104,000 \mathrm{~km}^{2}$.

The hydrogeochemical studies carried out here with, were intended to investigate, in a regional basis, the following topics: the characterization of the different hydrochemical types and their interrelations; the hydrogeochemical zoning and the discrimination of chemical types according to the stratigraphic units; the evolution of the groundwater's chemical composition along the percolation in the aquifer; the determination of the water quality according to the different uses and its chemical attack potential to the well equipment.

In this study 336 groundwater chemical analyses were employed. The hydrochemical data interpretation was based on: basic statistical processing, linear regression, trend surface analysis and isovalues maps.

The groundwaters have, generally, a very low salinity content and belong to two dominant chemical types: the calcium bicarbonate type and the calcium-magnesian bicarbonate type. The major ions responsible for the salinity content are the $\mathrm{HCO}_{3}^{-}, \mathrm{Ca}^{2+}$ and $\mathrm{Mg}^{2+}$. The calcium carbonate and the clay minerals of the sediments are furnishing these ions to the groundwater. The principal trend in the regional hydrogeochemical evolution according to the ionic increase is from northeast to southwest. Concerning the groundwater chemical quality for the various uses these waters comply with the required quality standards; the groundwater is encrusting or corrosive.

KAHN, Henrique

M-39

Caracterização mineralógica e tecnológica da jazida de fosfato do Maciço Alcalino de Anitápolis, SC. 01 de setembro. 219p. 1 vol. Orientador: Horstpeter Herbeto Gustavo José Ulbrich.

Resumo: O presente trabalho refere-se a estudos de caracterização mineralógica e tecnológica realizados no Maciço Alcalino de Anitápolis, SC.

O maciço é um corpo subcircular, situado em região dominada por granitóides pré- 
cambrianos, na borda da Bacia do Paraná. Ocupa uma área de $6 \mathrm{~km}^{2}$ e é coberto por depósitos de talus. Dados subsuperficiais indicam uma distribuição concêntrica das várias rochas alcalinas, agrupadas em séries, com as dos sienitos e nefelina sienitos na periferia, e a dos ijolitos e das ultramáficas ocorrendo no interior do maciço; o conjunto é cortado por veios de carbonatito sovítico, concentrados principalmente na porção central. O manto de alteração (ao redor de $30 \mathrm{~m}$ de espessura, com variações locais) é subdividido em três níveis. O superior (até $\pm 20 \mathrm{~m}$ ) é o depósito de talus, constituído por matacões e blocos, em matriz síticoargilosa; como minerais, predominam feldspatos, goethita, vermiculita e/ou esmectitas e caolinita, com algum quartzo (proveniente de rochas encaixantes), fosfatos secundários e magnetita; em um nível inferior (horizonte $A$ ), aparece também apatita residual, anfibólio e piroxênio. Sotoposto encontra-se o horizonte $B$, de rocha decomposta (espessura média de $10 \mathrm{~m}$ ), constituido por feldspatos, vermiculita, limonita, vários argilominerais, apatita, piroxênio e anfibólio. O seguinte, horizonte $C$, é de rocha semidecomposta e está colocado acima da rocha fresca; é o de menor expressão, e a sua mineralogia é a da rocha subjacente (ocorrendo biotita/flogopita, parcialmente alterada e calcita remanescente). A distribuição destes níveis é mostrada em mapas de isópacas.

Como atividade inicial, foi definida a distribuição dos principais minerais presentes (apatita, feldspatos, vermiculita, biotita/flogopita, calcita, piroxênio, anfib6lio e analcima), tanto no manto de intemperismo (minério residual) como na rocha fresca (minério de rocha). Os resultados aparecem lançados em mapas de isoteores de proporções de minerais (em peso, determinadas por difratometria semiquantitativa).

Com base na distribuição dos principais minerais interferentes no processo (vermiculita e piroxênio), foi definida uma tipologia preliminar do minério residual, caracterizada por oito tipos distintos; destes, apenas três perfazem $85 \%$ da jazida residual. Para o minério de rocha, definiram-se três tipos (ultramáfico, ijolítico e sienítico), coincidentes com as séries petrográficas citadas.

$\mathrm{Na}$ etapa seguinte, foram abertas cinco galerias (total de $210,5 \mathrm{~m}$ ) e constituídas 16 amostras compostas de minério residual, utilizadas para os estudos de caracterização tecnológica. As composições mineralógicas dessas amostras foram determinadas e comparadas com as previstas a partir dos estudos iniciais. As 16 amostras foram moídas e classificadas, e as frações obtidas analisadas química e mineralogicamente, de modo a determinar a composição mineralógica, o grau de liberação e a intensidade de recobrimento superficial da apatita, e as perdas de fósforo apatítico nas lamas. Estabeleceram-se também equações de correlação, para estimar as proporções de minerais a partir de parâmetros químicos. Uma das galerias, situada em área de ocorrência de carbonatito beforsítico, foi estudada em maior detalhe (8 amostras); sua mineralogia anômala é caracterizada pela presença de: dolomita, anquerita, vermiculita/esmectita, baritocalcita, alstonita, silica amorfa, witherita, magnetita e outros raros minerais acessórios. A partir destes estudọs, compuseram-se amostras para ensaios tecnológicos em usina piloto; os resultados então obtidos permitiram consolidar um modelo de tipologia de minério, para fins de beneficiamento e lavra, com o estabelecimento de cinco tipos de minério residual (A, B1, B2, C1 e C2), relacionados aos três níveis do perfil de alteração e às composições das rochas subjacentes.

Estudos de caracterização tecnológica foram também realizados em duas amostras compostas de minério de rocha (tipos ultramáfico e ijolítico); o tipo sienítico não foi estudado, em razão das similaridades do mesmo com o minério residual tipo A, o qual apresentou ótimo desempenho na etapa de beneficiamento. Ensaios de beneficiamento em bancada indicaram comportamentos similares para as amostras estudadas; a principal interferência no processo está relacionada ao conteúdo de veios de carbonatitos presentes e não à litologia dominante. 
Abstract: The present work is based mainly on mineralogical and technological characterization studies done on the phosphate deposit associated with the Anitapolis Alkaline Massif, Santa Catarina State, Southern Brazil.

The massif is subcircular, cropping out over $6 \mathrm{~km}^{2}$ as an intrusion in Precambrian granites, at the Eastern border of the Paraná Basin. It is almost entirely covered by talus deposits. Borehole data show a concentric rock distribution, which were grouped into series; syenite and nepheline syenite series are found as border varieties, while ijolite and ultramafic series are centrally located; sövite veins, although ubiquitous, are mainly concentrated in the central part. Three alteration levels (overall thickness of $30 \mathrm{~m}$, with pronounced variations) are observed. The talus deposit (at the most $20 \mathrm{~m}$ thick) it the uppermost, constituted predominantly by blocks of alkaline rocks, in a silty-argillaceous matrix; main minerals are feldspars, goethite, vermiculite and/or smectite and kaolinite, with some basement derived quartz, secondary phosphates and magnetite; a lower level (A horizon) shows residual apatite, amphiboles and pyroxenes. Below is the $B$ horizon of altered rock (average thickness of $10 \mathrm{~m}$ ); main minerals are feldspars, vermiculite, limonite, several clay minerals, apatite and pyroxene, with subordinate amphibole and magnetite. The lowermost $C$ horizon, poorly developed, lies on the top of fresh rock; it shows only incipient weathering, and its mineralogy is that of the underlying rock (calcite, if present, has not been leached out completely, and biotite/phlogopite is partially altered). The distribution of the several horizons is shown in isopach maps.

The distribution of main minerals (apatite, feldspars, vermiculite, biotite/phlogopite, calcite, pyroxenes, amphibole and analcime) was studied both in the weathered levels (residual ore) and in the fresh rocks (rock-ore). Mineral weight proportions, determined by semiquantitative diffraction methods, are plotted in equal contour maps.

Eight residual ore types were preliminarily defined, based on the previous studies, with due consideration for the main interfering minerals in the ore dressing (vermiculite and pyroxene); only three of them comprise about $85 \%$ of the residual ore. Three rock-ore types were defined (ultramafic ijolitic and syenitic), coinciding with the main petrographic series found in the massif.

In addition five galleries were opened, and 16 residual ore samples were prepared for technological studies. The mineralogical compositions were determined, and compared with the predicted values, defined by the previous district-wide mineralogical studies. The 16 samples were ground and sieved, and the size fractions analysed both chemically and mineralogically, in order to define the minerals distribution, the degree of liberation of apatite and its surficial coating by iron oxides-hydroxides, and the amount of loss of apatitic phosphorus in slimes. Several correlation equations were established to estimate minerals proportions from chemical data. One of these galleries, situated in a beforsitic area, was studied in more detail (8 samples); its anomalous mineralogy is characterized by dolomite, ankerite, vermiculite/smectite, baritocalcite, alstonite, amorphous silica, witherite, magnetite and other several unusual minerals as accessories. Ore dressing development was carried out in a pilot plant with composite samples based on the above studies; the results (only summarized in the present work) showed the need to redefine the residual ore types for dressing and exploitation steps. Five technologically different types were thus established (A, B1, B2, C1 and C2), which correspond to the three defined weathering levels and are related to the underlying fresh rock composition.

Technological studies were also performed in two composite rock-ore samples (ultramafic and ijolitic types); the syenitic type was not studied, on account of its similarity with the A residual ore type, which showed an excellent performance during dressing development tests. These two samples behaved similarly in batch flotation tests; the main interference is related to carbonate contents (or the amount of carbonatite veins found in the fresh rocks). 
MANO, Vinicius Gomes Taveira

Estudos geológicos e geotécnicos das descontinuidades rochosas "pillow lavas" e paleocanal nos basaltos de fundação da Barragem de Nova Avanhandava, Rio Tietê, SP. 17 de junho. 96p. 1 vol. Orientador: José Eduardo Siqueira Farjallat.

Resumo: O Aproveitamento Múltiplo de Nova Avanhandava localiza-se no trecho do Baixo Tietê, no Estado de São Paulo. As obras objetivam a geração de energia elétrica e a continuidade da hidrovia Tietê/ Paraná.

As unidades geológicas, mapeadas nas proximidades do local de estudo são os basaltos da Formação Serra Geral, os arenitos da Formação Adamantina e as Formações Superficiais. Geomorfologicamente a área situa-se no Planalto Ocidental do Estado de São Paulo.

Quanto aos estudos geológicos para a fundação da barragem e da eclusa, foram identificados quatro derrames basálticos e caracterizadas geotecnicamente as descontinuidades rochosas mais importantes.

Especial destaque é dado à ocorrência de um derrame de pillow lavas basálticas, onde se descreve, em detalhe, as feições macro e microscópicas. Apresenta-se considerações sobre o comportamento geotécnico deste material rochoso, que resultaram na sua não remoção, mesmo servindo como fundação da Casa de Força.

E relatada, também, a existência de um paleocanal no Rio Tietê, sua geometria e as modificações que se fizeram necessárias no Projeto Executivo para a compatibilização. Conclui-se que apesar de adotar-se uma rotina nos trabalhos de prospeç̧ão, deve-se estar atento para com feições geomorfológicas de ocorrência pouco freqüente.

Os resultados obtidos nos tratamentos de fundação das estruturas de concreto e obras de terra atingiram plenamente os objetivos esperados, com reduções significativas das vazões afluentes ao sistema de drenagem e das subpressões atuantes nas fundaçóes.

Conclui-se que foi muito importante o conhecimento geológico como instrumento de uma perfeita interação da obra e seu local de implantação.

Abstract: Nova Avanhandava dam complex is located at the downstream part of Tietê River, São Paulo State. The purpose of the project is to generate electrical energy as well as to keep the development of the Tietê/Paraná waterway project.

The geological units mapped in the surroundings of the site chosen for this study are basalts of Serra Geral Formation, sandstones of Adamantina Formation and Superficial Formations. Geomorphologically, the site is located in the Occidental Plateau of São Paulo State.

As regards geological studies for the foundation of the dam and of the embankment four basaltic spillings were identified and chief rock discontinuities were geotechnically characterized.

Special attention was given to the occurrence of a spilling of basalt pillow lava, the macro and microscopic fractures of which being described in details. The study also contains considerations on the geotechnical behaviour of this rock material which had not been removed and even served as the foundation of the power station.

Comments are also made on the existence of a Tietê river ancient channel, its geometry and the modifications which were deemed necessary on the Executive Project in order to render it adequate. As a conclusion one may say that despite adopting a routine prospecting work, geomorphological features which barely occur must be specially noticed. 
Results obtained when improving the foundation of concrete structures and soil embankments have fully reached the objectives estimated, thus significantly reducing affluent water flows towards the drainage system and also reducing sub-pressures exercised on the foundations.

As a final conclusion it must be pointed out that geological knowledge is very important as a means of obtaining perfect interaction between the construction and the implementation site.

MORALES, Norberto

Evolução litoestrutural das rochas pré-cambrianas da região de São João da Boa Vista. 02 de maio. 157p. 1 vol. Orientador: Fernando Flávio Marques de Almeida.

Resumo: Este estudo enfoca a área situada entre as cidades de São João da Boa Vista, Vargem Grande do Sul e São Roque da Fartura, no Estado de São Paulo. Está compreendida entre os paralelos $21^{\circ} 45^{\prime} \mathrm{S}$ e $22^{\circ} 00^{\prime} \mathrm{S}$ e é limitada a leste pelo Maciço Alcalino de Poços de Caldas, e a oeste pelos sedimentos da Bacia do Paraná.

As investigações tiveram por objetivo o reconhecimento dos tipos litológicos e das estruturas, e a reconstituição da evolução litoestrutural dos terrenos nos pré-cambrianos lá expostos.

Predominam migmatitos de estrutura bandada, oftalmítica e nebulítica, ocorrendo ainda gnaisses granulíticos, gnaisses anfibolíticos, gnaisses charnockíticos, leucognaisses, granitóides porfiróides, gnaisses ocelares, rochas granitóides intrusivas, gnaisses kinzigíticos e rochas cálcio-silicáticas. Tais rochas representam um complexo original de rochas ígneas plutônicas, com limitadas supracrustais associadas.

O exame das paragêneses permite estabelecer três etapas de metamorfismo, a primeira de fácies granulito, seguida da segunda em condiçōes de fácies anfibolito e a terceira etapa, de caráter retrogressivo, foi de baixo grau, em fácies xisto verde médio a baixo.

A estrutura de destaque é uma foliação tectônica, onipresente, acompanhada de lineação de estiramento, desenvolvidas em uma zona de cisalhamento dúctil de baixo ângulo, contemporânea ao metamorfismo de fácies anfibolito. A deformação e o metamorfismo desta etapa destroem as feições indicativas das condições mais enérgicas, de fácies granulito. Deformações tardias afetaram a foliação e a lineação, ao longo de zonas de cisalhamento dúctil de alto ângulo e de ondulações suaves associadas.

A migmatização das rochas ocorre em três etapas distintas, a primeira anterior ao evento a deformação principal, de caráter anatético. A segunda fase é mais marcante, desenvolvendo sintectonicamente a migmatização regional. Eventos tardios e pós-tectônicos são representados por pequenas lentes, bolsões, veios e diques.

As feições rúpteis são dadas por fraturas e falhas direcionais de pequeno rejeito, ao longo das quais o metamorfismo de baixo grau foi mais intenso.

Abstract: This work presents petrographic and structural features of the Precambrian rocks exposed at the region of the countries of São João da Boa Vista, Vargem Grande do Sul and São Roque da Fartura (São Paulo State, Brazil).

Recognization of lithologic types and structures, and the reconstitution of the evolution of those terrains were the purposes of the investigations.

Migmatites, high grade gneisses and granitoids represent the most important rocks. The migmatites show several structures, prevailing stromatic ophthalmitic and nebulitic types. The composition 
of the migmatites changes from dioritic to tonalitic in the mesocratic portions, reaching a granitic composition in the leucocratic portions.

High grade gneisses are represented by: dioritic to monzodioritic biotite-hornblende gneisses bearing hypersthene and/or diopside and showing banded structure; kinzigitic gneisses, bearing granate, sillimanite, biotite and cordierite; charnockitic gneisses, whose acid composition changes from alkaligranitic to alkali-syenitic terms.

The principal bodies of granitoids show porphyroid features, with megacrystals of K-feldspar in a slightly foliated matrix, resembling an igneous texture, grading laterally and progressively to "augen" gneisses.

The paragenetic studies indicate a high grade metamorphism of granulite facies, locally preserved within a dominant mineral assemblage of amphibolite facies. All the lithologies show a retrogressive event, in conditions of middle to low greenschist facies of metamorphism.

The major structure is a prominent and pervasive low angle foliation, striking SE (and SW), dipping SW (and SE). A stretching and mineral subhorizontal lineation is present, oriented mostly ESEWNW. Scarce intrafolial folds present axial plane parallel to subparallel to foliation and axis mostly oriented parallel to lineation. These structures were interpreted as having been originated in a low angle ductil shear zone, developed at conditions of amphibolite facies, replacing the granulite facies assemblage.

High angle shear zones and associated deflections modify the foliation and lineation orientations. Small open folds show axial planes parallel to those shear zones. At macroscopic scale, the foliation presents gentle ondulations associated to folds or ductil shear zones, both mostly oriented NNE.

Based on overprinting patterns of foliation upon felsic mobilizates, three phases of migmatization can be recognized. The first one is a pretectonic anatectic migmatization. The second one is a sintectonic phase, and represents the main regional phase. Late posttectonic events occur as lenses, veins, dykes and irregular small bodies.

Joints and faults represent the brittle features, the faults with cataclastic rocks and intense retrometamorphism along the main zones.

\section{NÓBREGA, Maria Teresa de}

Contribuição ao estudo da estabilização de solos tropicais com adição de cal para fins rodoviários. Aspectos mineralogicos e morfológicos de alguns solos das Regiōes Sul e Sudeste do Brasil. 22 de abril. 189p. 1 vol. Orientador: Adilson Carvalho.

Resumo: A estabilização de solos com adição de cal, que é uma técnica comumente empregada em países das zonas temperadas, tem encontrado muita dificuldade de aplicação no Brasil e no domínio tropical em geral.

Os mecanismos envolvidos nessa estabilização são pouco conhecidos, mas citam-se normalmente a capacidade de troca, floculação e aglomeração das argilas e as reações pozolânicas como as responsáveis pela alteração e melhora das propriedades geotécnicas das misturas solo-cal.

Com o objetivo de contribuir para o avanço do conhecimento da estabilização com adição de cal em materiais tropicais selecionou-se 3 solos e 2 alteritas, expressivos em termos de área e que apresentam dificuldades de emprego na construção rodoviária, nas regiões sul e sudeste do país: o Latossolo Roxo, a Terra Roxa Estruturada, o Latossolo Vermelho Escuro orto, as alteritas de granito e de gnaisse. 
Optou-se por abordagem pedológica e geoquímica, utilizando como instrumentos de pesquisa as técnicas mineralógicas e micromorfológicas, além dos ensaios mecânicos que funcionaram como controle das variações de comportamento hídrico e mecânico dos materiais antes e depois da adição de cal. Os materiais foram estudados sob três condições diferentes: natural, compactado sem tratamento prévio e compactado após adição de cal.

Os solos são de textura argilosa, constituídos por caolinita, oxi-hidróxidos de ferro e gibbsita (esta última ausente na TRE). As alteritas são siltosas a silto-arenosas, constituídas basicamente por caolinita, mica (biotita alterada), quartzo e feldspato (pouco).

A adição de cal confere a todos os materiais um aumento na capacidade de suporte, redução na expansão e na contração, com intensidades variáveis em função da natureza do material envolvido.

A análise mineralógica mostrou que a cal afeta os minerais da fração argila, promovendo uma amorfização na gibbsita e na caolinita. Nas alteritas é a caolinita que é afetada preferencialmente, enquanto que a mica (biotita alterada) não mostra sinais de ataque. Os produtos neoformados são, entretanto, mais difíceis de serem detectados pelas técnicas de difração de raios-X e análise termo diferencial.

Os estudos micromorfológicos, por outro lado, revelam a existência dos produtos de neossíntese, a sua distribuição e as relações que mantêm com os constituintes do plasma.

Mostram, ainda, que a compactação destrói parcial ou totalmente a organização natural dos materiais, dando origem a um novo arranjo, onde são visíveis sinais de instabilidade: orientações plásmicas estriadas e fissuras paralelas, que em geral delimitam lamelas. Estes indícios são observados principalmente nos solos. As misturas solo-cal compactadas exibem arranjos diferentes destes, onde os sinais de instabilidade são atenuados ou suprimidos, dependendo do material utilizado.

Em conclusão, verifica-se que tanto a mineralogia quanto a organização original dos materiais influenciam o resultado da estabilização.

Abstract: The soil stabilization with lime is a well known technic in countries of temperate zone, but its utilization in Brazil and the tropical countries as a general, has been rather problematic.

The mechanisms involved in the stabilization are not well known and cation exchange capacity, clay flocculation and agglomeration and pozzolanic reactions have been mentioned as responsible for the alteration and improvement of the geotechnical properties of the soil lime mixture.

In order to contribute to the better acknowledgement of the soil stabilization with lime addition, 3 soils types and 2 alterites were selected on the basis of their extensive occurrence and their bad quality as road construction materials. The soils selected were a LR, a TRE and a LE of a granite and a of gneiss.

The methods of study were mainly pedological and geochemical based on mineralogical and micromorphological analysis associated with mechanical testes in order to control the hydric and mechanical behaviour of the materials before and after the lime treatment. The material were studied within 3 different condition: natural, compacted without treatment and compacted with treatment.

The soils present a clay texture and are constituted by kaolinite, iron oxides and hydroxides and gibbsite (the latter not present in TRE). The alterites present a silty to sandy silt texture and are formed mainly by kaolinite, mica (weathered biotite), quartz and few feldspar.

The lime addition to these materials represents an increase in the bearing capacity and a reduction of expansion and contraction, a different intensities according to the nature of these material.

The mineralogical analysis has shown that lime affects the clay fraction, leading to a 
amorphization of gibbsite and kaolinite. In the alterites, the kaolinite is the most affect while the mica remains nearly antouched. Nevertheless, the newly formed materials are rather difficult to be detected by XRDA and ATD.

On the other hand, the micromorphological studies, show the presence of the products of neosynthesis and its distribution and relationship with the plasma constituents. It is also shown that the compactness destroyes partially or totally the natural organization of the material, given origin to a new one were signs of instability are rather clear: plasmic orientation and parallel fissures limiting lamellae. These evidences are better observed in the soils. The compacted soil-lime mixture show different organizations, where the signs of instability are attenuated or suppressed, depending on the material.

As a conclusion, it can be said that the mineralogy as well as the original organization of the materials has influence on the stabilization result.

NOGUEIRA JUNIOR, Jehovah

Possibilidades de colmatação química dos filtros e drenos da Barragem de Porto Primavera (SP) por compostos de ferro. 15 de agosto. 229p. 2 vol. Orientador: Kenitiro Suguio.

Resumo: $\mathrm{O}$ conhecimento dos mecanismos geoquímicos e fatores ambientais, que regem a laterização nos sedimentos quaternários do Rio Paraná, em Pontal do Paranapanema, é de fundamental importância no estudo da possível colmatação química por compostos de ferro, dos drenos da Barragem de Porto Primavera, em construção no Rio Paraná. Os mecanismos de solubilização e precipitação do ferro, dentro do contexto ambiental regional, bem como a evolução dos compostos de ferro são, tanto para a laterização quanto para a colmatação, basicamente os mesmos.

A presente pesquisa abrangeu, portanto, um conhecimento do meio ambiente do ponto de vista geológico, especialmente sedimentológico e um conhecimento dos processos que regem a laterização e sua evolução. Abrangeu, também, uma modelação desses processos de forma a fornecer subsídios para o entendimento do fenômeno da colmatação química dos drenos de uma barragem.

Os estudos desenvolvidos basearam-se nas investigações realizadas para o projeto da Usina de Porto Primavera, durante o período de julho de 1976 a dezembro de 1985, constituindo três etapas de trabalho que são apresentadas como partes distintas da pesquisa.

Parte 1 - Estudo dos depósitos aluviais quaternários do Rio Paraná.

Este estudo teve como base os mapeamentos geologicos, sondagens mecânicas, ensaios in situ e análises de laboratório que foram desenvolvidos para o projeto da Barragem de Porto Primavera ao longo da extensa planície aluvial da margem direita do Rio Paraná. Contemplou, também, o Arenito Caiuá, que ocorre como substrato dos aluviões na região e poderia representar a principal fonte primária de ferro nos atuais processos de laterização.

Parte 2 - Estudo dos processos de laterização e da evolução dos perfis lateríticos e conglomerados ferruginosos.

A existência de níveis concrecionados e de conglomerados fortemente cimentados por compostos de ferro, nos aluviōes do Rio Paraná, mostra que a região apresenta condições ambientais favoráveis à mobilização e precipitação do ferro. Essas condições foram pesquisadas a partir de sondagens, ensaios de campo e laboratório e correlações geológicas, obtendo-se subsídios para a elaboração de um modelo para a laterização e sua evoluçâo como modeladora do relevo. 
Parte 3 - Estudo do fenômeno da possível colmatação química dos drenos da futura Barragem de Porto Primavera por compostos de ferro.

Conhecidos os mecanismos que regem a laterização e estabelecimento de um modelo, foi desenvolvido um estudo da possível colmatação química dos drenos da Barragem de Porto Primavera devida à precipitação de compostos de ferro. Este estudo abrangeu uma análise dos mecanismos que governam a colmatação no sistema drenante de uma barragem a partir de condições ambientais diversas das atuais, decorrentes da formação do reservatório. Foram propostas, ainda, medidas preventivas visando a minimização ou até a eliminação da colmatação na futura barragem e demais barragens de terra brasileiras.

Abstract: The understanding of environmental factors and geochemical mechanisms that rule the laterization phenomenon in the Pontal do Paranapanema cenozoic sediments is of paramount importance in the study of possible chemical clogging by iron compounds in the drains of the Porto Primavera Dam, under construction in the Paraná River. The mechanisms of solubility and precipitation of iron, within a regional environmental context, as well as the evolution of iron compounds are basically the same, both for the laterization and the clogging processes.

The current research reported here has taken into account the knowledge of the environment under geological and sedimentological context, the knowledge of the processes that rule the laterization and its evolution, and a modelling of these processes, in order to subsidize the understanding of the chemical clogging phenomenon of the dam drains.

Based on borehole dada in situ tests, laboratory tests and mapping that have been carried out, the cenozoic alluvial deposits of Parana River and the processes of laterization and evolution of sand and gravel beds strongly cemented by iron compounds, present in the alluvia, were studied. The Caiua Sandstone, which occurs as the bedrock for the regional alluvia and should represent the main primary source of iron in the processes, was also considered.

After the mechanisms that rule the laterization were defined and the geochemical model established, a study of the possible chemical clogging of the drains of Porto Primavera Dam was executed, and the mechanisms that could lead to this clogging due to environmental conditions with the creation of the reservoir were analysed.

Prevent measures that will be adopted in order to minimize or eliminate the clogging in the future dam are presented, as well as suggestions for the study, prevention and correction of the phenomenon in other Brazilian earth dams.

\section{ROHN, Rosemarie}

Bioestratigrafia e paleoambientes da Formação Rio do Rasto na borda leste da Bacia do Paraná (Permiano Superior, Estado do Paraná). 05 de agosto. 225p. 1 vol. Orientador: Oscar Rösler.

Resumo: O estudo de fósseis e litologias da Formação Rio do Rasto (Grupo Passa Dois) ao longo de 11 estradas, do sul ao nordeste do Estado do Paraná e de 1 estrada no extremo-norte de Santa Catarina deu suporte a correlações entre as colunas de diversas áreas, à definição de biozonas, à interpretação dos possíveis paleoambientes e a novas considerações sobre a história evolutiva da Bacia do Paraná durante o final do Permiano. A parte da seqüência estudada abrange as porções anteriormente designadas Membro Serrinha (cerca de 1/4 da coluna, a partir da base) e Membro Morro Pelado, cujas características 
litológicas, no entanto, não parecem sustentar adequadamente estas subdivisões. Do sul ao centro-norte do Estado do Paraná, na área aflorante, a espessura da Formação Rio do Rasto atinge $\mathbf{4 2 0} \mathrm{m}$, diminuindo acentuadamente da região de São Jerônimo da Serra para a de Santo Antônio da Platina, onde se encontram porções mais marginais da bacia.

As análises dos fósseis (formalmente descritos em outros trabalhos especialmente preparados para esta dissertação) buscaram dados paleoecológicos, de correlação interbacinal, bioestratonômicos e bioestratigráficos; também fundamentaram a maior parte das correlações entre os afloramentos e entre as seções colunares compostas, tendo permitido estimar os mergulhos aproximados das camadas (entre $0,5^{\circ} \mathrm{e}$ $0,9^{\circ}$ ) e, em alguns casos, os rejeitos de falhas de gravidade (muito freqüentes na região do Arco de Ponta Grossa).

A distribuição, a diversidade e a abundância de conchostráceos dão sustentação a zoneamento bioestratigrafico relativamente detalhado, comportando, em ordem ascendente, as Zonas Cyzicus sp., Monoleaia unicostata micropolygonata, Paranaleaia supina-Asmussia sp., Asmussia regularis (que compreende a Subzona Palaeolimnadiopsis subalata) e o "Intervalo de Conchostráceos Superior". Os conchostráceos evidenciam principalmente ambientes continentais de águas rasas, relativamente quentes e são típicos das regióes semi-áridas. Estes fósseis não lograram importantes correlações interbacinais.

Os bivalves, relativamente comuns na parte inferior da formação, estão distribuídos nas Zonas Leinzia similis (inferior) e ?Palaeomutela platinensis (superior, com a Subzona Nothoterraia acarinata em sua porção inferior). Aquelas formas da segunda zona, incluindo algumas similares a espécies do Permiano Superior de outras regiões gondvânicas, certamente representam ambientes continentais de águas calmas. Já os bivalves da zona inferior parecem ser endêmicos, de águas um pouco mais agitadas, possivelmente com salinidade mais elevada.

Os megafósseis vegetais possibilitaram o estabelecimento das Zonas Pecopteris dolianitii (inferior, com 3 subdivisões) e Schizoneura gondwanensis (superior, com 2 subdivisões). Os elementos são típicos da última fase de desenvolvimento da Flora Glossopteris, permitindo correlação principalmente com o Grupo Ecca Superior, Grupo Beaufort Inferior e a Formação Madumabisa do sul da África e a Formação Raniganj da Índia. Estes fósseis ocorrem em relativa abundância, mas são pouco representativos da vegetação global e apresentam diversidades não muito elevada. Há diversos elementos com possíveis adaptações xeromórficas.

A análise palinológica de uma amostra da localidade-tipo do Membro Serrinha, praticamente da base da Formação Rio do Rasto, sugere correlação principalmente com os palinomorfos dos depósitos da Zona Tapinocephalus da parte inferior do Grupo Beaufort Inferior. Endossando ainda as correlações anteriores indicadas pelo estudo de tetrápodes da Serra do Cadeado, a deposição da unidade na área estudada pode ter ocorrido no intervalo equivalente ao Kazaniano Superior-Tatariano Inferior, tendo possivelmente cessado um pouco mais cedo na região de Santo Antônio da Platina.

Além dos fósseis mencionados, ainda foram constatados estromatólitos nodulares (particularmente na base da formação), pequenos gastrópodes, ostracodes, escamas de peixes (em maior abundância no nordeste do Estado), e ainda icnofósseis (principalmente na porção inferior da formação). Estes fósseis apóiam as interpretações ambientais já mencionadas ou, pelo menos, não parecem indicar ambientes estritamente marinhos.

Os depósitos sedimentares, quase todos avermelhados, exceto na porção basal da seqüência, foram classificados em 17 tipos. O conjunto das evidências litológicas, bioestratonômicas e paleoecológicas sugere que a Formação Rio do Rasto representa deposição em grandes lagos rasos, com oscilação freqüente do nível de água, da área de recobrimento e possivelmente também da salinidade, sob condições 
climáticas variavelmente secas; supõe-se que os lagos eram limitados por terras preponderantemente baixas, com dunas eólicas em extensas áreas, vegetação melhor desenvolvida próximo às margens, e drenagem provavelmente efêmera, apenas efetiva nos eventos de chuvas torrenciais. Os lobos de suspensão e as sigmóides, acumulados nos lagos próximo às desembocaduras dos cursos de água, assim como, os turbiditos das regiões de costa afora, devem atestar as maiores descargas durante as cheias. Em certas fases, principalmente durante a deposição da metade inferior da formação, a dinâmica dos lagos parece ter sido influenciada por intensas tempestades; oscilações mais fracas, como as provocadas pelo vento, deixaram marcas em diversos depósitos da base ao topo da seqüência.

Os dados apontam para a incidência de uma fase inicial de condições climáticas bastante secas, provavelmente sucedida por dois importantes intervalos de melhora climática; o primeiro intervalo um pouco mais úmido é caracterizado pelo desenvolvimento expressivo de glossopterídeas, pecopterídeas, bivalves e conchostráceos (M.unicostata micropolygonata); o segundo é representado, principalmente, pela ingressão de Schizoneura gondwanensis e pela máxima diversidade em conchostráceos; durante este intervalo pode ter havido ligeiro levantamento/basculamento tectônico da área de Reserva-Cândido de Abreu, sugerido, em parte, pela ocorrência de grandes intraclastos em dois diamictitos. $O$ terço superior da formação evidencia novo acentuado recrudescimento climático, aparentemente com poucas fases de maior umidade, tendo provocado o desaparecimento de diversas espécies da fauna e da flora. Há registro de invasões cada vez mais freqüentes dos lagos por dunas eólicas, até a sua colmatação definitiva, a qual representa o início da deposição da Formação Pirambóia.

Abstract: Study of the Rio do Rasto Formation (Passa Dois Group) along 11 roads in southern to northeastern Paraná State and 1 road in northern Santa Catarina State, Brazil, has provided the basis for stratigraphical correlation of vertical profiles, establishment of biozones, interpretation of possible paleoenvironments and new inferences on the history of the Paraná Basin at the end of the Permian. The studied sequence comprises the Serrinha Member (the lowest 1/4 of the formation) and the Morro Pelado Member. However, the lithologies observed do not provide reasonable support for this subdivision. The thickness of the formation does not exceed $420 \mathrm{~m}$ in the studied area and decreases markedly from São Jerônimo da Serra towards Santo Antônio da Platina near the margin of the basin.

Fossils were analyzed for interbasinal correlations and for paleoecological, biostratinomic and biostratigraphic interpretations. The fossils found the most important correlations among outcrops and vertical profiles. They also helped to estimate regional dips of the strata (around $0.5^{\circ}-0.9^{\circ}$ ) and, in some cases, the approximate offset of the vertical faults, very common in the region of the Ponta Grossa Arch.

The geographical distribution, diversity and abundance of the conchostracans supports the establishment of the following bịozones (in ascending order): Cyzicus sp. Zone, Monoleaia unicostata micropolygonata Zone, Paranaleaia supina-Asmussia sp. Zone, Asmussia regularis Zone (including the Palaeolimnadiopsis subalata Subzone) and the "Upper Conchostracans Interval". These organisms are typical of freshwater ponds and shallow lakes in warm, semi-arid regions. The conchostracans seem not to be very important in interbasinal correlations.

Bivalves, most frequent in the lower part of the formation, are distributed in the Leinzia similis Zone (almost entirely at the base of the formation) and the ?Palaeomutela platinensis Zone (including the Nothoterraia acarinata Subzone). The bivalves of the second zone, which comprise some forms similar to other Upper Permian Gondwanic species, probably lived in calm fresh waters, whereas the bivalves of the Leinzia similis Zone seem to be endemic associated with more agitated waters and possibly with higher salinity. 
Two zones of fossil plants were defined: the Pecopteris dolianitii Zone (in the lower part, with 3 subdivisions) and the Schizoneura gondwanensis Zone (in the upper part, with 2 subdivisions). The elements are typical of the last phase of development of the Glossopteris Flora, as reported for the Upper Ecca Group, the Lower Beaufort Group and the Madumabisa Formation in southern Africa, and the

Raniganj Formation in India. The fossil plants are relatively abundant, but not very representative of the regional vegetation. Neither zone shows great diversity. Elements with possible xeromorphic adaptations are common.

Palynological analysis of a single sample from the type-locality of the Serrinha Member, almost at the base of the Rio do Rasto Formation, suggests correlation with forms of the Tapinocephalus Zone from the basal part of the Lower Beaufort Group. In accordance with previous observations based on the study of tetrapods from the Serra do Cadeado, the sequence in the studied area may have been deposited in the Late Kazanian to the Lower Tatarian; in northeastern Paraná State (Santo Antônio da Platina), however, deposition may have ended earlier.

,Other fossils observed in the formation, such as nodular stromatolites (mainly at the basal part of the unit), small gastropods, ostracodes, abundant fish scales (particularly in northeast Parana) and trace fossils (mainly in the lower part of the formation), are consistent with the above-mentioned paleoenvironmental interpretations and do not include any strictly marine species.

The sedimentary deposits were classified in 17 types. Lithologic, biostratinomic and paleoecological evidence suggests that the predominantly red sequence of the Rio do Rasto Formation accumulated in great shallow lakes characterized by water level and possibly salinity oscillations within an variable arid context. The lakes were surrounded by lowlands, which contained marginal vegetation, eolian dunes and probably ephemeral streams. Flood stages would have caused the deposition of suspension lobes and sigmoidal bars near the mouths of tibutaries and turbidites farther offshore in the lakes. Occasionally, specially during the deposition of the lower part of the sequence, the lakes were influenced by heavy storm episodes; weaker wave action, such as that produced by winds, also left marks in many stata, throughout the formation.

The sequence apparently began to accumulate under quite arid conditions, followed by more humid conditions, probably in two distinct intervals. The expressive development of glossopterids, pecopterids, bivalves and conchostracans (M.unicostata micropolygonata) would have occurred in the first interval, whereas Schizoneura gondwanensis and several conchostracans appeared in the second interval. In the latter interval may have occurred mild tectonic uplift of the area near Reserva-Cândido de Abreu, as suggested by the presence of two anomalous diamictites with large intraclasts. The upper third of the formation documents the return of rigorous arid conditions, that alternated with only a few, short, less severe intervals. Many floral and faunal species disappeared at this time, and eolian dunes invaded the lakes with greater frequency, finally filling then up and setting the stage for deposition of the Pirambóia Formation.

M-45

SANTOS, Angela Maria Martins Marques dos

Caracterização petrológica dos granulitos básicos da Folha de Guaranésia (MG). 10 de maio. 106p. 1 vol. Orientador: Marcos Aurélio Farias de Oliveira.

Resumo: A área de enfoque deste trabalho está localizada na parte sul do Estado de Minas Gerais 
compreendendo parte das Folhas Topográficas de Guaranésia e Guaxupé. A NW da cidade de Guaranésia têm-se uma faixa de rochas granulíticas bandadas onde são registradas rochas granulíticas de composição básica. O objetivo deste trabalho foi o de estudar este grupo especial de rocha no que se refere a sua mineralogia e química. Além dos estudos petrográficos, foram feitas análises químicas de rocha total para elementos maiores e menores. Pares clino-ortopiroxênios foram analisados sob microssonda eletrônica.

Um mapa litológico esquemático foi montado a partir de dados de campo coletados por alguns autores que fizeram anteriormente um primeiro reconhecimento na área. No mapa é possível separar-se duas litologias dominantes: migmatitos a SW de Guaranésia e granulitos a NW. Intercalações de granulitos máficos foram identificadas, tanto no domínio migmatítico quanto nos granulitos, no entanto, são mais freqüentes neste último.

Os granulitos básicos de Guaranésia são granulitos gabronoríticos e monzonoríticos. Os granulitos gabronoríticos são constituídos essencialmente por plagioclásio ( $\mathbf{A n}_{40-55}$ - 43\%), clinopiroxênio (salite - 12\%), ortopiroxênio (hiperstênio - 10\%) e anfibólio (20\%). Para os granulitos monzonoríticos, têmse plagioclásio ( $\mathrm{An}_{20-40}-59 \%$ ), clinopiroxênio (salite - 4\%), ortopiroxênio (hiperstênio - 6\%) e anfibólio (19\%) bem como a frequeência em torno de $10 \%$ de quartzo e feldspato potássico. Os minerais acessórios mais frequentes são os opacos, seguidos pelo zircão e titanita.

Foram analisados os pares clino-ortopiroxênios, deste grupo de amostras, sob microssonda eletrônica. Cálculos termométricos, utilizando-se as calibragens de WOOD \& BANNO (1973), WELLS (1977) e KRETZ (1982) apresentam um valor médio de $780^{\circ} \mathrm{C} \pm 60$, para a temperatura do metamorfismo que afetou este grupo de rochas. A pressão estimada é da ordem de 7,5 quilobares, comparativamente aos dados de WILSON (1976), correspondendo a uma profundidade de crosta em torno de $26 \mathrm{~km}$.

Com os dados químicos de rocha total e parâmetros de Niggli, foram construídos diversos diagramas propostos na literatura. Os diagramas MgO-CaO-Feo de WALKER (1960) e ACF de ORVILLE (1969) indicam uma provável origem sedimentar. Evidências que indicam uma origem ígnea são apontadas nos diagramas que relacionam parâmetros de Niggli C versus $\mathrm{mg}, 100 \mathrm{mg}$-C-(al-alk) bem como valores de elementos menores como $\mathrm{Cr}$ versus $\mathrm{mg}$, Ni versus $\mathrm{mg} \mathrm{e} \mathrm{Cr}$ versus $\mathrm{TiO}_{2}$, todos propostos por LEAKE (1964). As amostras de granulitos básicos de Guaranésia também se situam no campo ígneo, proposto por VAN DER KAMP (1968). Comparações químicas com as principais séries magmáticas basálticas apontam semelhanças com a série basáltica subalcalina com representantes das subdivisões calco-alcalinas e toleíticas, segundo os limites de MAcDONALD \& KATSURA (1964), IRVINE \& BARAGAR (1971). Para o diagrama de JENSEN (1976) os granulitos de Guaranésia se posicionam no campo dos basaltos toleíticos ricos em $\mathrm{Fe}$.

Os valores plotados das amostras de Guaranésia apresentam uma distribuição aleatória e um espalhamento grande pelos campos discriminados nos diagramas propostos por PEARCE \& CANN (1973), com relação a Ti/100-Zr-Sr/2 e Ti/100-Zr-3y e PEARCE \& NORRY (1979) de $\mathrm{Zr} / \mathrm{Y}$ versus $\mathrm{Zr}$ para os diversos ambientes tectônicos de formação de rochas no Fanerozóico. Foi obtida melhor resposta nos diagramas propostos por GILL (1979). Nos diagramas que relacionam $\mathrm{mg}(100 \mathrm{MgO} /(\mathrm{MgO}+\mathrm{FeO})$ versus teores de $\mathrm{Ni}$ e $\mathrm{Cr}$ os valores dos granulitos de Guaranésia estão concentrados no campo referente aos basaltos arqueanos.

Abstract: This paper presents the results of a study of granulite rocks from Guaranésia region on south, Minas Gerais State. In this area two main rocks groups are present: migmatites and granulites. Small lenses or bands of basic granulites occur rather in migmatites or granulites.

The pyroxene granulites from Guaranésia region show a basic composition with $\mathrm{SiO}_{2}$ mean values about $49.8 \%$. 
Petrography studies show that the basic granulites have a gabbronoritic to monzonoritic composition made up essentially by plagioclase $\left(\mathrm{An}_{40-45}\right)$, clinopyroxene (salite), orthopyroxene (hypersthene) and amphiboles. Opaques, zircon and sphene are accessory minerals.

Microprobe analyses of clino- and orthopyroxenes are presented. The mineral pairs of clinoorthopyroxenes give an average temperature of $780 \pm 60^{\circ} \mathrm{C}$ while a pressure of $7.5 \mathrm{kbar}$, estimated by $\mathrm{Al}_{2} \mathrm{O}_{3}$ content of pyroxenes (according WILSON, 1976).

Major and traces elements $(\mathrm{Cr}, \mathrm{Ni}, \mathrm{Rb}, \mathrm{Sr}, \mathrm{Ba})$ have been determined in 10 samples of basic granulites. Some critical plots are presented. Evidence provided by chemical variation trends suggests that basic granulites of Guaranésia region have probably been derived from basic igneous rocks, rather than calcareous-dolomitic shales. The chemical variation trend of basic granulites are similar to that of subalkalic magma series.

$\mathrm{Ni}(\mathrm{ppm}), \mathrm{Cr}(\mathrm{ppm}), \mathrm{Al}_{2} \mathrm{O}_{3}(\%)$ and $\mathrm{TiO}_{2}(\%)$ as function of mg number $(100 \mathrm{Mg} / \mathrm{Mg}+\mathrm{Fe})$ diagram, show basic granulites values in the field of Archaean tholeiites.

\section{VARAJÃo, Angélica Fortes Drumond Chicarino}

Gênese das jazidas de caulinita e bauxita de Vargem dos Óculos, Quadrilátero Ferrífero, MG. 04 de agosto. 168p. 1 vol. Orientador: Adolpho José Melfi.

Resumo: As jazidas de caulinita e bauxita de Vargens dos Óculos encontram-se na calha do Sinclinal da Moeda, sobre rochas do Grupo Itabira. A heterogeneidade litológica deste grupo, propocia uma alteração geoquímica diferenciada, culminando com a formação de depressões, cujo conjunto encontra-se envolvido por vertentes, associadas às cristas constituídas por itabiritos. Desta forma, três unidades morfológicas são definidas na área, as unidades de alta, média e baixa vertente.

As unidades de alta e média vertente são capeadas por uma couraça ferruginosa isalterítica, a interface entre a média e baixa vertente por uma couraça alumino-ferruginosa e, a unidade de baixa vertente por um material argiloso, predominantemente caulinítico.

Na unidade de baixa vertente, onde se localizam as jazidas em estudo, dois perfis de alteração se sobrepõem em discordância estrutural. Um perfil inferior, cuja evolução se deu in situ, a partir dos filitos carbonáticos do Grupo Itabira e um perfil superior alóctone oriundo da deposição de fragmentos laterizados, pertencentes às pretéritas couraças alumino-ferruginonas desenvolvidas na média vertente.

$\mathrm{Na}$ unidade de baixa vertente, condições de hidromorfia são atuantes, propiciando o desenvolvimento do mecanismo de deferruginização sobre ambos jazimentos, que concorre para a formação de expressiva fácies bauxítica, na jazida de bauxita, acompanhando ou seguido de uma importante silicificação, na jazida de caulinita, tendo como consequência a formação de significativa fácies caulinítica.

Abstract: The kaolinite and bauxite ore deposits of Vargem dos Óculos are situated at the Moeda Syncline trough, lying over rocks of the Itabira Group.

The lithological heterogeneity of this Group, provides a differentiated geochemical alteration, which induces the formation of depressions and slopes, associated to itabirite crests. Morphological units, therefore, can be defined, the upper middle and low slope.

The upper and middle units are covered by an alterite iron crust; the interface between the middle and low one by an alumino-ferruginous crust and the low slope unit by an argillaceous material, predominantly kaolinic. 
At the low unit, where the deposits are located, two alteration profiles are overlaid in structural unconformity. An inferior one, with an in situ evolution from carbonate phyllites of the Itabira Group and the superior one allochthonous is derived from deposition of fragmented material of ancient alumino-ferruginous crust, developed at the middle slope.

At the low unit a hydromorphic environment and reducing conditions predominate. This leads to the development of deferruginization, on both deposits and forming expressive bauxitic facies, in the bauxite deposit. Such mechanism is accompanied or followed by a silicification, at the kaolinite deposit, with the formation of significant kaolinitic facies.

VARAJÃO, Cesar Augusto Chicarino

Estudo comparativo das jazidas de bauxita do Quadrilatero Ferrifero, MG - micromorfologia, geoquímica, geomorfologia e sensoriamento remoto. 13 de setembro. 213p. 1 vol. Orientador: Adilson Carvalho.

Resumo: O estudo comparativo das jazidas de bauxita do Quadrilátero Ferrífero revelou que estas apresentam características macroscópicas, estruturais, mineralógicas, químicas e micromorfológicas análogas.

Morfologicamente, encontram-se em diferentes níveis altimétricos, que apresentam um nítido controle litoestrutural, descartando-se, portanto, a hipótese da associação dos depósitos à superfície de aplainamento.

Com base nas características químicas e geomorfológicas, efetuou-se a classificação dos depósitos e a escolha dos depósitos-tipo para estudos de detalhe, com ênfase para as características micromorfológicas das fácies.

Somente em dois depósitos (Faria e Macaquinho) pode-se comprovar uma gênese a partir de um protominério sedimentar. Na Jazida Morro da Arataca, verificou-se uma filiação a partir de filitos. Entretanto, para a maioria dos depósitos, associados ao Grupo Itabira, atribuiu-se uma gênese a partir de filitos dolomíticos.

Considerando-se o modelo de evolução de relevo adotado, as características semelhantes dos depósitos e a datação relativa dos mesmos, a partir da idade dos Sedimentos Gandarela e Fonseca, atribuise uma idade máxima eocênica para os depósitos desta região.

A prospecção de jazidas de bauxita, através da interpretação de imagens digitais do sensor "thematic mapper" realçadas, revęlou um método eficaz, onde foi possível a discriminação das formações superficiais (bauxita, canga, solo).

Abstract: The comparative study of the bauxite deposits of the Quadrilatero Ferrifero has shown that those reveal similar structural facies, mineralogical, chemical and morphological characteristics.

In morphological terms, these deposits are related to different altimetric levels which show apparent lithostructural control in such a way that their association with erosion levels can be rejected.

Based on chemical and morphological characteristics, a classification of the deposits was achieved as well as the choice of type deposits to detailed studies, with emphasis to facies micromorphology.

An origin from a sedimentary protore has been established in just two deposits (Faria and Macaquinho). At Batatal and Morro da Arataca, a relation with phyllites was verified. Therefore, for most 
of the deposits, associated to the Itabira Group, an origin from dolomitic phyllites was established.

Comparing the relative ages of the deposits with Gandarela and Fonseca sediments, and with the adopted model of evolution of the relief, an eocene age can be stated, as the maximum age for the deposits of the region.

The bauxite deposits prospection by means of the Landsat-TM Sensor enhanced images, has proved to be an effective method where the superficial formations (bauxite, iron crust and soil) could be distinguished.

VASCONCELLOS, Antonio Carlos Buzolin Cabral de

O Grupo Andrelândia na região norte de Ouro Fino, MG. 29 de agosto. 199p. 1 vol. Orientador: Mario Cesar Heredia de Figueiredo.

Resumo: Na região a norte de Ouro Fino, extremo sudoeste do Estado de Minas Gerais, foi individualizada, ao longo de uma faixa de orientação aproximada EW e largura média de 6,5 km, uma seqüência metavulcano-sedimentar proterozóica. Litoestratigraficamente, caracteriza-se por um conjunto de 9 unidades que foram agrupadas, da base para o topo, em quatro seqüências principais: seqüência gnáissica inferior (unidade dos biotita gnaisses tonalíticos); seqüência xisto-quartzítica (unidades dos quartzitos placosos e biotita xistos quartzo-feldspáticos); seqüência gnáissica intermediária (unidade dos gnaisses bandados); e, seqüência gnáissico-quartzítica (unidades dos biotita gnaisses quartzosos, hornblenda-biotita gnaisses ocelares, muscovita-quartzo-biotita xistos, muscovita quartzitos e anfibolitos com gnaisses cálciosilicáticos). A equivalência e continuidade física dessa seqüência metavulcano-sedimentar com as unidades do Grupo Andrelândia (da região que lhe empresta o nome) puderam ser evidenciadas a partir da correlação do empilhamento litoestratigráfico e de levantamentos regionais de campo.

Uma unidade ortognáissica pré-tectônica intrusiva no Grupo Andrelândia se apresenta como corpos tabulares concordantes e, em geral, de grande extensão lateral. Informalmente denominada de granito-gnaisses Taguar, essa unidade é constituída por ferrohastingsita-piroxênio granitos, biotitaferrohastingsita granitos e granodioritos e ferrohastingsita-biotita granitos, todos gnáissicos e portadores de magnetita.

As unidades do Grupo Andrelândia e os granito-gnaisses Taguar registram uma história deformacional com 5 fases superpostas de dobramentos. A primeira fase $\left(D_{1}\right)$ tem como registro principal uma foliação tectônica $S_{1}$ preservada de modo reliquiar; dobras referentes a esta fase, não foram encontradas, e sua orientação e vergência são desconhecidas. A organização estrutural do Grupo Andrelândia está controlada por uma articulação de nappes de dobramento atribuíveis à segunda fase $\left(\mathrm{D}_{2}\right)$, que tem seus elementos lineares orientados preferencialmente segundo N55E- S55W, indicando um sentido de transporte tectônico aproximado de N35W. Essas duas primeiras fases desenvolveram-se sob condições metamórficas da fácies anfibolito médio (primeira isógrada da sillimanita). Sinformas e antiformas normais, abertas e apertadas, desenhadas pela foliação principal das unidades do Grupo Andrelândia e pelos seus contatos correspondem às fases de dobramentos tardios superpostos $D_{3}, D_{4}$ e $D_{5}$, que são orientados, respectivamente, segundo NE/SW, WNW-ESE e NNE-SSW. A fase $D_{3}$ do Grupo Andrelândia corresponde à fase $\mathrm{D}_{1}$ dos metassedimentos da Formação Eleutério-Pouso Alegre e se desenvolveu sob condições da fácies xisto verde. Zonas lineares de cisalhamento tiveram um desenvolvimento penecontemporâneo a parte das fases de dobramento. 
A partir da análise litoestratigráfica regional do Grupo Andrelândia e correlatos são caracterizadas, na Faixa Alto Rio Grande, três zonas isópicas principais, alongadas segundo a direção média ENE e denominadas, das porções externas para as internas da faixa, de Grupo São João del Rei, Grupo Andrelândia e Grupo Itapira. Em cada uma destas zonas são descritos diversos estágios evolutivos (de rift a plataformal e a vulcânico flysch) parte admitindo referência paleogeográfica no paleocontinente "São Francisco", parte nas porções internas da faixa. Ao lado das diferenças individuais entre seus estágios equivalentes, reconhece-se um diacronismo no estabelecimento e desenvolvimento das três zonas isópicas.

Os dados geocronológicos disponíveis para as unidades do Grupo Andrelândia, seu embasamento e os granito-gnaisses Taguar permitem posicionar a Faixa Alto Rio Grande no Proterozoico Médio. Para o período de estabelecimento e desenvolvimento paleogeográfico, reconhece-se como limites inferior e superior, respectivamente, os intervalos de $1.900-1.800 \mathrm{Ma}$. e $1500-1.400 \mathrm{Ma}$. O primeiro evento tectônico, responsável pelo desenvolvimento da foliação $\mathrm{S}_{1}$ e de prováveis inversões paleogeográficas, deve ter ocorrido em torno de $1.400 \mathrm{Ma}$. Para o segundo evento tectônico, responsável pela organização estrutural principal da Faixa Alto Rio Grande e pelo underthrusting da mesma sob os terrenos da Nappe de Empurrão Socorro-Guaxupé, os dados existentes não são conclusivos, ora sugerindo idades entre $1.200 \mathrm{e}$ $1.000 \mathrm{Ma}$., ora entre 850 e $800 \mathrm{Ma}$. Como limite superior seguro para os eventos tardi-tectônicos é reconhecido o intervalo de 500 - $550 \mathrm{Ma}$.

Abstract: In the Ouro Fino region, southwestern Minas Gerais State, a Proterozoic metavolcanosedimentary sequence was individualized along a belt of approximately EW orientation and with average width of about $6.5 \mathrm{~km}$. Lithostratigraphically it is characterized by 9 units which were grouped, from base to top, into four main sequences: lower gneissic sequence (tonalitic biotite gneisses unit); schist-quartzitic sequence (platy quartzites and quartz-feldspathic biotite schists unit); intermediate gneissic sequence (banded gneisses unit); and gneissic-quartzitic sequence (quartz-rich biotite gneisses, hornblende-biotite augen gneisses, muscovite-quartz-biotite schists; muscovite quartzites and amphibolites with calc-silicatic gneisses units). Based on the lithostratigraphic correlation and regional field work, the equivalence and physical continuity of this metavolcano-sedimentary sequence with the Andrelândia Group (from the homonymous region) can be established.

A pre-tectonic orthogneissic unit, intrusive into the Andrelândia Group, occurs as tabular, concordant bodies and generally with large lateral extension. This unit, informally named as Taguar granitegneisses, consists of ferrohastingsite-pyroxene granites, biotite-ferrohastingsite granite-granodiorites, and ferrohastingsite-biotite granites, all of them gneissic and magnetite-bearing.

The Andrelândia Group sequences and the Taguar granite-gneisses were deformed by 5 superposed folding phases. The first phase $\left(D_{1}\right)$ has a reliquiar $S_{1}$ tectonic foliation preserved, but folding related to this phase has not been found and its orientation and tectonic vergence are unknown. The structural organization of the Andrelândia Group is controlled by folding nappes attributed to the second phase $\left(\mathrm{D}_{2}\right)$, with N55E- S55W oriented linear elements indicating a tectonic transport towards about N35W. These two phases were developed under middle-amphibolite facies conditions (first isograd of sillimanite). Normal synforms and antiforms, open to tight, showed by the main foliation of the Andrelândia Group units and by their contacts, correspond to the superposed late $\mathrm{D}_{3}, \mathrm{D}_{4}$ and $\mathrm{D}_{5}$ phases, which are oriented NE-SW, WNW-ESE and NNE-SSW, respectively. The $D_{3}$ phase of the Andrelandia Group corresponds to the $D_{1}$ phase of the Eleutério-Pouso Alegre Formation metasediments and was developed under greenschist facies conditions. Linear shear zones had a coeval development to some of these folding phases.

Three main isopic zones, elongated along an ENE direction, are characterized in the Alto 
Rio Grande Belt, based on the regional lithostratigraphic analyses of the Andrelandia Group and correlates. These zones are named, from the external to the internal portions of the belt, as São João del Rei, Andrelândia, and Itapira Groups. Each of these zones have several evolutionary stages (from rifting to platformal sedimentation to flysch-volcanic stage), some of them with paleogeographic reference to the São Francisco paleocontinent while others to internal portions of the belt. Besides individual differences between equivalent stages, a diachronism in the establishment and development of the three isopic zones is recognized.

The existing geochronological data for the Andrelândia Groups units, their basement and the Taguar granite-gneisses suggest that the Alto Rio Grande Belt is of Middle-Proterozoic age. The lower and upper limits for the paleogeographic establishment and development, are considered the 1,900-1,800 Ma and 1,500-1,400 Ma intervals, respectively. The first tectonic event, responsible for the $S_{1}$ foliation and probable paleogeographic inversions, should have occurred at about 1,400 Ma ago. For the second tectonic event, responsible for the main structural organization of the Alto Rio Grande Belt and its underthrusting beneath the terrains of the Socorro-Guaxupe Thrust Nappe, the available data is inconclusive suggesting either 1,200-1,000 Ma or $850-800 \mathrm{Ma}$ age intervals. The late-tectonic events have a well defined $550-500 \mathrm{Ma}$ interval upper limit.

\section{9}

CASTELO BRANCO, Raimundo Mariano Gomes

Geologia e geofisica do Diatrema Redondão SW do Estado do Piaut. 30 de maio. 151p. 1 vol. Orientador: Benjamim Bley de Brito Neves.

Resumo: O presente estudo foi conduzido numa área de $13 \mathrm{~km}^{2}$ situada no SW do Estado do Piaui, Nordeste do Brasil. Faz parte da pesquisa estudos geologicos gerais de uma área de $32.000 \mathrm{~km}^{2}$ envolvendo a borda sul da Bacia do Maranhão e onde a primeira está inserida. $O$ objetivo principal foi a integração de dados geológicos, geofísicos e de sensoreamento remoto do diatrema kimberlítico do Redondão com o intuito de conhecer a geologia de superfície, estruturação do corpo em profundidade e contexto estrutural envolvido na região de ocorrência. Foram aplicados os métodos magnetométrico, gamaespectrométrico e de eletrorresistividade integrados com uma metodologia de análise de lineamentos e estudos gerais em produtos de sensoreamento remoto. Com base na integração e interpretação dos dados e na utilização de programas para computadores, obteve-se um modelo para o corpo do Redondão. O Diatrema Redondão, constituído por brechas kimberlíticas de conduto, apresenta níveis ou horizontes bem caracterizados nas sondagens elétricas verticais, tem forma de funil (pipe) que se estende a profundidades da ordem de $2 \mathrm{~km}$, de onde se originou. A fonte de alimento do conduto é um dique (dique infradiatrema), com cerca de $2 \mathrm{~km}$ de espessura e $20 \mathrm{~km}$ de extensão, orientado para NE e encaixado em faixas cataclásticas do Lineamento Transbrasiliano. Na borda sul da bacia são marcantes os lineamentos estruturais NE e NW, detectados na análise de lineamentos e interpretação de mapas aeromagnetométrico. São também discutidos aspectos 
petrográficos das litologias da área do Redondão e da borda sul da bacia, aspectos de geologia estrutural e de geofísica envolvidos na área.

\begin{abstract}
The present study involves an area with $13 \mathrm{~km}^{2}$ situated in the South of Piaui State, Northeastern Brazil. General geologic studies have been done in the South border of Maranhão Paleozoic Basin with an area of $32.000 \mathrm{~km}^{2}$. Its main objective was the interaction between geologic, geophysics and remote sensing data in the Redondão Kimberlitic Body. The knowledge of its superficial and subsuperficial structures was possible with magnetometric, gamaspectrometric and electrical surveys integrated with studies of lineaments in remote sensing products. Computer programs were used in the treatment and interpretation of data. A model was proposed to the Redondão structure. There are typical kimberlitic breccias, with levels or horizonts specified by electrical method, it has a funnel shape (pipe) that goes to 2 $\mathbf{~ k m}$ under the actual surface. Under the pipe, there are a feeder dike, of kimberlitic nature, with $2 \mathrm{~km}$ thickness and $20 \mathrm{~km}$ in length oriented to NE direction. This dike is along cataclastic zone of the Transbrasiliano Lineament. It the South border of the basin are dominants NE and NW structural trends. This study presents also petrographic aspects of rocks from Redondão Area and from the south border of Maranhão Basin, structural geologic aspects and regional geophysical interpretation.
\end{abstract}

\title{
M-50
}

\section{CHIEREGATI, Luiz Antonio}

Aspectos mineralogicos, genéticos e econômicos das ocorrências diamantíferas da região nordeste do Paraná e sul de São Paulo. 16 de outubro. 180p. 1 vol. Orientador: Darcy Pedro Svisero.

Resumo: As ocorrências diamantíferas do nordeste paranaense e sul do Estado de São Paulo são conhecidas desde meados do século passado e vem sendo exploradas, de modo intermitente, até os dias de hoje. O diamante ocorre tanto em cascalheiros de leito atual dos rios, como também em aluviões recentes e antigos, constituindo os denominados monchões. Os depósitos são em geral de pequenas dimensões, sendo raros aqueles que suportam um trabalho mecanizado de lavra e beneficiamento. $\mathrm{O}$ conteúdo de diamantes nos depósitos também é pequeno, variando os teores entre $0,04 \mathrm{e} 0,08 \mathrm{ct} / \mathrm{m}^{3}$. A produção total dos garimpos oscila entre 400 e $1.000 \mathrm{ct} /$ ano de diamantes além de pequena quantidade de ouro obtido como subproduto.

As principais ocorrências situam-se na bacia do Rio Tibaji, desde os arredores da cidade homônima até cerca de $50 \mathrm{~km}$ a jusante de Telêmaco Borba. Outros rios diamantíferos são o Laranjinha, Cinzas, Jaguariava, Jaguaricatu, Itararé e Verde, este último integralmente no Estado de São Paulo. Do ponto de vista geologico, as ocorrências estão posicionadas sobre unidades estratigráficas do Devoniano, Permocarbonífero e Permiano da Bacia de Paraná, sendo rara a presença de depósitos mineralizados, sobre terrenos geologicamente mais antigos ou mais novos do que os mencionados.

Além dos parâmetros econômicos e geológicos, os depósitos foram estudados quanto ao seu conteúdo mineralógico, buscando-se caracterizar a fonte desses sedimentos bem como a eventual presença de minerais paragenéticos do diamante, indicativos de suas fontes primárias. Entre os minerais pesados verificou-se a predominância das fases ultra-estáveis, zircão, turmalina e rutilo, além da presença marcante de ilmenita, magnetita, goethita, cromita e monazita. Subsidiariamente verificou-se a presença de granadas de cores variadas, anfib́lios, piroxênios, epídoto, estaurolita, apatita, xenotima, anatásio, espinélio verde, ouro e o próprio diamante. 
Determinações químicas por meio de microssonda eletrônica, efetuadas em granadas, ilmenitas e espinélios da região, não revelaram, entretanto, indícios da presença de kimberlitos. As granadas são constituídas principalmente da molécula de almandina, com pequenas proporçóes das moléculas de piropo e grossulária. As ilmenitas por sua vez apresentam baixo conteúdo de magnésio, não correspondendo às de natureza kimberlítica. Quanto à presença de minerais de lamproítos na área, os dados obtidos com os espinélios não permitem avançar muito nessa hipótese, já que as características dos minerais-índice utilizados na prospeção dessas rochas não se encontram suficientemente divulgados na literatura especializada.

No que se refere ao diamante, o mesmo é de pequenas dimensões, com peso médio de $0,10 \mathrm{ct}$ não obstante termos registrados o achado de pedras com peso de até 10 ct. $O$ hábito predominante é o rombodecaédrico, seguido das formas de transição para o octaedro. Subordinadamente ocorrem cristais geminados agregados policristalinos e o próprio octaedro, além de exemplares irregulares e fraturados. $\mathbf{O}$ diamante é predominantemente incolor e de qualidade gemológica.

A origem desse diamante tem sido motivo de controvérsia ao longo dos tempos. A distribuição das ocorrências conhecidas, invariavelmente situadas sobre os terrenos paleozóicos da Bacia do Paraná, sugere que o diamante esteja sendo liberado dos sedimentos rudáceos dessas unidades. Por outro lado, o balizamento das ocorrências pelas estruturas tectônicas do Arco de Ponta Grossa e a presença de rochas alcalinas e alcalino-ultrabásicas na porção central dessa estrutura, permite supor a existência de rochas matrizes primárias do diamante, a elas associadas.

Apesar das evidências apontarem para um modelo de reciclagem de diamante, a localização espacial e temporal de suas fontes primárias não deve ser abandonada, uma vez que seu entendimento traz uma importante contribuição para o conhecimento da evolução tectônica dessa porção do nosso continente.

Abstract: Diamonds have been exploited in northeastern Paraná and southern São Paulo States since the middle of the last century. The mineral occurs in alluvial, elluvial and colluvial deposits, in concentrations ranging from 0.04 up to $0.60 \mathrm{ct} / \mathrm{m}^{3}$, with annual output fluctuating around $1000 \mathrm{ct} /$ year. In addition, gold has been recovered as a by product of concentrates in many localities.

The main occurrences and deposits are located in the basins of Tibaji, Laranjinhas, Cinzas, Jaguariaiva and Itararé Rivers. Field surveys revealed that the deposits are related to the lower (Furnas Formation) and middle (Itarare Subgroup) portions of the Paleozoic sequences of the sedimentary Paraná Basin. Occurrences on Precambrian basement seem to be rare and sporadic.

In order to investigate the source of local diamonds, mineral concentrates were systematically sampled at more then one hundred different targets within the area of recorded diamond exploitation. As identified by optical microscopy and X-ray diffraction the mineralogical assemblage comprises magnetite, goethite, hematite, limonite, ilmenite, zircon, rutile, tourmaline, chromite, monazite, garnets, hornblende, epidote, staurolite, apatite, xenotime, anatase, gahnite, corundum, kyanite, gold and diamond. Garnets and ilmenites were analysed in the electron microprobe, in order to search for the primary source of local diamonds. Garnets are mainly magnesium-poor and chromium-depleted almandine. Magnesium and chromium are absent in ilmenites as well. Therefore, the absence of $\mathrm{Cr}$-pyrope garnet and $\mathrm{Mg}$-ilmenite, the common mineral indicators of kimberlite, reinforces the hypothesis based on field work that the studied diamonds have been recycled from the rudaceous units of the Paraná Basin.

The study of several parcels of diamonds from local deposits (garimpos) revealed grain sizes granulometry from 0.01 to 5.0 ct. Diamonds weighing 10 or more carats have been recorded occasionally. However, large stones of tens or even hundreds carats like those found in western Minas Gerais, have never 
been recorded in the Tibaji and neighboring areas. As commonly observed elsewhere in Brazil and most worldwide localities dodecahedra is the most common crystal morphology, followed by forms intermediate between dodecahedral and octahedral crystals. Unrounded octahedra, flat twins, pyramidal cube, polycrystalline aggregates, cleavage fragments and borts are less common. As previously observed crystalline inclusions are mainly olivine, garnet, spinel and sulphides. The great majority of the diamonds are colorless $(90 \%)$, the remainder showing variations of green brown and yellow. It is estimated from the examination of parcels totalizing 5,000 carats that $70 \%$ are gemological diamonds.

The origin of the diamond from Tibaji and neighboring areas has always been a matter of discussion. Apart from old ideas linking these diamonds to acid rocks or kimberlite sources located in Southern Africa via pre-drift glacial transport, current hypothesis are centered on the possibility (or not) of primary sources in the area. Unfortunately, there is still little informations on the nature and distribution of the heavy minerals found together with the diamond, as well as on geological and tectonics characteristics of the area. Although no kimberlite minerals was found during this research enhancing the possibility that the diamond has been recycled from the rudaceous units of the Paraná Basin, this result has to be interpreted in the light of the large size of the area investigated. On the other side until systematic surveys permit a firm conclusion as to the presence or absence of primary sources, the possibility of the presence of kimberlite and/or lamproite intrusions in the area can not be excluded, given the huge amount of basic/ultrabasic dikes associated with the Ponta Grossa Arch.

\section{CIGUEL, José Henrique Godoy}

Bioestratigrafia dos tentaculoidea no flanco oriental da Bacia do Paraná e sua ocorrência na América do Sul (Ordoviciano-Devoniano). 29 de maio. 287p. 2 vol. Orientador: Oscar Rösler.

Resumo: A microestrutura esqueletal foliada ocorrente na concha dos tentaculitóideos, além de aspectos relacionadas a filogenia, permitem aventar a hipótese de que o grupo possuiu um ancestral comum com os cefalópodos, durante o Cambriano Superior. Já, a partir do Ordoviciano exibem uma evolução paralela, porém com convergência adaptativa com os representantes da Classe Cephalopoda.

Os tentaculitóideos ocorrem na América do Sul, do Ordoviciano ao Devoniano. No entanto, o grupo não tem sido utilizado com fins bioestratigráficos, a exemplo de várias bacias de outros continentes.

O estudo dos tentaculitóideos provenientes da Argentina (formações Trapiche, Mogotes Negros, Los Espejos e Salar del Rincón), Bolívia (formações Pizarras Cordillera Real, Catavi e Icla), Brasil (formações Trombetas e Ponta Grossa), Paraguai (formações Vargas Pena e Cariay), Peru (Formação Excelsior) e Uruguai (formações Cordobés e La Paloma), demostraram diversidade a nível genético. Entre os gêneros registrados pela primeira vez na América do Sul, tem-se: Uniconus (2 espécies; 1 nova e 1 redefinida), Multiconus (1 espécie nova), Heteroctenus (2 espécies novas), Turmalites (1 espécie nova), Nowakia (1 espécie nova), Paranowakia (2 espécies novas), Variella (1 espécie nova), Homoctenus (9 espécies novas), Seretites (3 espécies novas e 1 redefinida) e Dmitriella (2 espécies novas). A presença de Styliolina ( 2 espécies novas) era duvidosamente referida como ocorrente e Tentaculites (20 espécies novas, 2 se mantêm), que possuíam o registro comprovado no continente.

A potencialidade na utilização dos tentaculitóideos como guias bioestratigráficos ficou melhor evidenciada no flanco oriental da Bacia do Paraná (Formação Ponta Grossa), onde os estudos se desenvolveram com minucioso controle de campo e laboratório. Para essa região foram estabelecidas 
Cenozonas, Zonas de Amplitude Concorrente a Zonas de Apogeu a partir de 31 seções colunares descritas, entre as quais, 19 são utilizadas no presente trabalho.

As Cenozonas são denominadas pelos algarismos 1, 2, 3 e 4 . As Zonas de Amplitude Concorrente são: U.crotalinus e T.gorceixensis; T.clarkensis, H.barbosensis e H.carvalhensis; e T.brannerensis e S.jaculus. As Zonas de Apogeu: U.crotalinus e S.jaculus.

Essa proposta de bio- e cronoestratigrafia para a faixa aflorante da Formação Ponta Grossa no Estado do Paraná, corrobora em parte com a bioestratigrafia da unidade baseada em palinomorfos. A idade da formação, conforme a distribuição dos tentaculitóideos, situar-se-ia entre Zlichoviano e o Frasniano.

Em termos paleoclimático os tentaculitóideos sugerem a existência de águas mais frias no flanco oriental em relação ao setentrional. Paleogeograficamente atestam a distribuição mundial dos mares devonianos, que ultrapassou os limites da Província Malvinocáfrica, concomitantemente a ampla irradiação adaptativa do grupo. Biogeograficamente, nesta província, tem-se a presença de gêneros ocorrentes em outras regiões. As espécies tem registro regional e provavelmente evoluíram por diferenciação ou por diversificação.

A presença dos icnofósseis e assembléias fossilíferas sugerem um ambiente deposicional para a formação, como situado entre a região litorânea e o sublitoral externo. A profundidade máxima dificilmente excederia 90 metros. Mas, as icnofácies, fauna e estruturas deposicionais sugerem o predomínio do ambiente sublitoral interno, com a lâmina d'água situando-se entre 40 e 60 metros de profundidade. Os fósseis exibem uma mescla de elementos faunísticos e limites difusos, dificultando sobremaneira o estabelecimento de comunidades estanques. Apenas os lingulídeos mostram indícios de comunidade, a qual, deve ser precedida pela identificação das tanatocenoses e tafocenoses, mesmo assim, possuem amplas recorrências.

A partir da distribuição cronológica dos fósseis coniformes, faz-se proposta preliminar da amplitude dos tentaculitóideos, para os seis países sul-americanos mencionados.

Abstract: The foliated skeletal microstructure of the shell of tentaculitoids, as well as aspects related to phylogeny, suggests that the group possessed a common Late Cambrian ancestor with the cephalopods. From the Ordovician onwards they exhibit a parallel evolution with adaptive convergence with representatives of the Class Cephalopoda.

The tentaculitoids occur in South America from the Ordovician to the Devonian. However, the group has not been used for biostratigraphic purposes, as it has been in various basins on other continents.

The study of tentaculitoids occurring in Argentina (Trapiche, Mogotes Negros, Los Espejos and Salar del Rincón Formations), Bolivia (Pizarras Cordillera Real, Catavi and Icla Formations), Brazil (Trombetas and Ponta Grossa Formations), Paraguay (Vargas Pena and Cariay Formations), Peru (Excelsior Formation), and Uruguay (Cordobés and La Paloma Formations) demonstrated diversity at the generic level. Genera registered for the first time in South America include: Uniconus (2 species; 1 new and 1 redefined). Multiconus (1 new species), Turmalites (1 new species), Nowakia (1 new species), Heteroctenus ( 2 new species), Paranowakia (2 new species), Variella (1 new species), Homoctenus (9 new species), Seretites (3 new species and 1 redefined), Dmitriella (2 new species). The presence of Styliolina is here confirmed and two new species are created. Tentaculites ( 22 species, of which 20 are new) has the broadest geographic and temporal record on the continent.

The potential for the utilization of tentaculitoids as biostratigraphic guides is best shown on the eastern flank of the Paraná Basin (Ponta Grossa Formation), where studies were undertaken with detailed 
field and laboratory control. Cenozones were established for this region, as well as Concurrent Range Zones and Acme Zones, with 31 columnar sections described, 19 of which are presented here.

The Cenozones are designated by the numbers $1,2,3$, and 4 in ascending order. The three Concurrent Range Zones are the U.crotalinus and T.gorceixensis Zone the T.clarkensis, H.barbosensis and H.carvalhensis Zones and the T.brannerensis and S.jaculus Zone. The two Acme Zones are the U.crotalinus and S.jaculus zones.

This proposal for the bio- and chronostratigraphy of the outcrop belt of the Ponta Grossa Formation in the Parana State agrees in part with the biostratigraphy of the unit based upon palynomorphs. The age of the formation, according to the distribution of the tentaculitoids, is Zlichovian to Frasnian.

In palaeoclimatic terms, the tentaculitoids suggest the existence of cold waters on the eastern flank in relation to the northern flank. Palaeogeographically, they attest both to the widespread distribution of Devonian seas and to the great adaptive radiation of the group, which surpassed the limits of the Malvinokaffric Realm. Biogeographically, genera occur in this realm which are known from other regions. Species are more limited regionally and probably evolved by differentiation and diversification.

The presence of ichnofossils and fossil assemblages suggest a depositional environment for the Ponta Grossa Formation located in the littoral to the outer sublittoral regions. The maximum depth most probably did not exceed 90 metres. Moreover, the ichnofacies, fauna and depositional structures suggest the predominance of an inner sublittoral environment, located between 40 and 60 metres depth. The fossils show a mixture of faunal elements with poorly-defined community limits, making the certain identification of communities extremely difficult. Only the lingulids allow for the identification of thanatocoenoses and taphocoenoses, both of which recur commonly in the sequence.

From the chronological distribution of these coniform fossils, a preliminary proposal for the range of the tentaculitoids is made for the six above-mentioned South American countries.

\section{GIUSTI, Donizeti Antonio}

Contribuição à geologia ambiental no Município de Curitiba, PR. 01 de junho. 115p. 1 vol. Orientador: Nelson Ellert.

Resumo: O presente estudo consistiu no mapeamento geológico de modo a contribuir com o planejamento da ocupação urbana e industrial do Município de Curitiba. Para tanto foram feitos estudos geofísicos e hidrogeológicos e perfis de poços tubulares profundos que evidenciaram dados quanto às estruturas e contatos geológicos, configuração topográfica do embasamento cristalino, lençol freático e direções de fluxo da água subterrânea.

O cadastramento das atividades existentes e suas localizações forneceram subsídios para o diagnóstico, interpretações e prevenção de processos de degradação ambiental.

Através da sobreposição de cartas de usos e ocupação do solo em relação à geologia e hidrogeologia e contando com o conhecimento das litologias, são feitas recomendações sobre a ocupação urbana e industrial. Em certos casos, são propostos remanejamentos de ocupações existentes e em alguns casos, reflorestamentos.

Desse modo, esta proposta se consubstância como uma contribuição para os planos de desenvolvimento urbano do Município de Curitiba. 
Abstract: Geological studies were made to contribute to planing the future urban and industrial occupation of Curitiba area, PR. Geophysical and hydrogeological studies showed: the structural geology and geological contacts, the water-table and groundwater flow directions; topographical configuration of the underlaying crystalline basement.

The listing of different land occupations and its locations represents a subside to the diagnosis, forecast and prevention processes of environmental degradation.

By means of the superposition of land use and territory occupation maps and geological and hydrogeological maps, recommendations are made to alter the present urban and industrial occupations forms.

This research represents a tentative contribution of environmental geology to the urban development and planning of Curitiba area.

HASSUDA, Seiju

M-53

Impactos da infiltração da vinhaça de cana no Aqǘffero Bauru. 31 de agosto. 92p. 1 vol. Orientador: Aldo da Cunha Rebouças.

Resumo: A área estudada está localizada no Município de Novo Horizonte situado no centro-oeste do Estado de São Paulo. Na região, ocorrem sedimentos cretáceos do Grupo Bauru que constituem um aqüífero livre e poroso, explorado para fins de abastecimento doméstico e industrial.

Sobre este aqǘf́ero, cuja extensão no Estado de São Paulo é de $104.000 \mathrm{~km}^{2}$, a atividade canavieira tem apresentado um grande crescimento, fazendo com que um grande volume de vinhaça se infiltre no solo e cause uma considerável poluição hídrica, já considerada crítica em certas áreas.

Este trabalho enfoca a problemática da infiltração da vinhaça numa área piloto do Aqüífero Bauru. Seu objetivo básico foi o desenvolvimento de metodologia de campo para determinação do impacto dessa prática.

Os resultados obtidos nesta pesquisa caracterizam claramente os impactos que a infiltração da vinhaça causa à água subterrânea, tornando-a inadequada para o consumo humano. Os seguintes parâmetros excederam os padrões de potabilidade: o nitrogênio amoniacal foi encontrado com valores entre > 0,005 e $9,8 \mathrm{mg} / \mathrm{l} ;$ o magnésio, entre 12,0 e $210,0 \mathrm{mg} / \mathrm{l} ;$ o alumínio, entre > 0,02 e $23,0 \mathrm{mg} / \mathrm{l} ;$ o ferro, entre > 0,005 e 60,0 mg/l; o manganês, entre 5,0 e $60,0 \mathrm{mg} / \mathrm{l}$; o cloreto, entre 4,0 e $640,0 \mathrm{mg} / \mathrm{l}$.

Face os resultados obtidos, faz-se necessário aplicar urgentemente a legislação que permita efetiva proteção dos recursos hídricos subterrâneos, principalmente porque a atividade em questão gera grande volume de efluente, disposto diretamente sobre importantes domínios aqüíferos do Estado de São Paulo, na forma de infiltração ou fertirrigação.

Abstract: The study area is located in Novo Horizonte which is in the central west region of the São Paulo State. The geology of the area is characterized by Cretaceous deposits of Bauru Group which is underlain by the Serra Geral Formation. The extent of Cretaceous aquifer in the São Paulo State is $104,000 \mathrm{~km}^{2}$ (square kilometres) and therefore constitutes a major exploitable aquifer. This aquifer is used for domestic and industrial water supplies.

Sugar cane milling is a major economic activity in the region and sugar cane is widely cultivated over the aquifer. Groundwater may become polluted from the sugar cane milling process from the 
infiltration of molasses (alcohol production residues). Many milling operations produce large volumes of molasses and groundwater pollution, from molasses infiltration, is considered high in these areas.

This thesis focuses on the problem of molasses infiltration in the pilot area of Bauru aquifer. The main purpose of the study has been to develop field methodology to determine the impact of molasses infiltration.

The results of this research indicate molasses infiltration has caused the groundwater to become polluted making it inadequate for human consumption. The following measures were found in water which exceeded drinking water standards: ammonia nitrogen $>0.005 \mathrm{mg} / 1$ to $9.8 \mathrm{mg} / \mathrm{l}$; magnesium 12.0 to 210.0 $\mathrm{mg} / \mathrm{l}$; aluminum $>0.02$ to $23.0 \mathrm{mg} / \mathrm{l}$; iron 5.0 to $60.0 \mathrm{mg} / \mathrm{l}$ and chloride 4.0 to $640.0 \mathrm{mg} / \mathrm{l}$.

The results from this research suggest the applicability of existing legislation could allow effective protection of groundwater resources. Presently sugar cane milling generates large volumes of effluents which are directly disposed on important aquifers in São Paulo State by infiltration or liquid fertilization (irrigation). These sugar cane milling practices must abid by legislation to protect potable groundwater.

\section{MENDES, Júlio César}

Aspectos mineralogicos, geológicos e econômicos da esmeralda de Santa Terezinha de Goiás. 19 de setembro. 163p. 1 vol. Orientador: Darcy Pedro Svisero.

Resumo: Os garimpos de esmeraldas de Santa Terezinha de Goiás estão situados no centro-oeste goiano, aproximadamente a $23 \mathrm{~km}$ a nordeste da cidade de Santa Terezinha de Goiás.

Regionalmente, nesses garimpos distinguem-se três conjuntos tectônicos distintos: 1) uma seqüência de rochas de baixo grau metamórfico constituída de clorita xistos, talco xistos e biotita xistos, portadora da mineralização esmeraldífera; 2) uma associação gnáissico-anfibolítica a SE; 3) um conjunto granito-gnáissico cortado por um batolito granítico a NW.

Através dos trabalhos de mapeamento geológico na area legal de garimpagem, inserida no contexto regional anteriormente descrito, detectou-se a existência de dois conjuntos litológicos distintos, representados pelo complexo granito gnáissico e pela Seqüência Santa Terezinha, composta pelas litologias referidas.

As descrições petrográficas referentes ao perfil de um poço de $117 \mathrm{~m}$ de profundidade revelaram que as rochas mineralizadas em esmeraldas são representadas por quartzo-carbonato-talco xistos (1) e biotita/flogopita xistos, ao passo que as rochas isentas de esmeraldas são compostas por biotita/flogopita-carbonato xistos (2), muscovita-clorita-carbonato quartzo xistos e blastomilonitos. Essas litologias pertencem às rochas de baixo grau da Seqüência Santa Terezinha. Nas rochas pertencentes aos níveis mineralizados, a turmalina, o berilo (esmeralda) e os carbonatos exibem biaxialidade anômala, sugerindo que as encaixantes da esmeralda foram submetidas a esforços tectônicos após a formação da esmeralda.

As esmeraldas de Santa Terezinha de Goiás caracterizam-se principalmente pela sua cor verdeintensa, por índices de refração com valores de $\mathbf{n}_{\delta}=1,580-1,597, \mathbf{n}_{\boldsymbol{\omega}}=1,586-1,599$, birrefringência entre 0,001 e 0,010 e por uma densidade relativa variando de 2,673 a 2,774 com valores médios de 2,711. Análises de microssonda eletrônica nessas esmeraldas revelaram que entre os 6 xidos principais, o $\mathrm{SiO}_{2}$ varia de 62,33 a $65,30 \%, \mathrm{o}_{2} \mathrm{O}_{3}$ de 12,5 a 13,13\%, o $\mathrm{MgO}$ de 2,48 a 2,77\% e o $\mathrm{Na}_{2} \mathrm{O}$ de 1,31 a 2,91\% em peso, sendo que 
o $\mathrm{BeO}$ foi tomado como valor constante igual a $12,5 \%$. Com relação aos cromóforos $\mathrm{Cr}$ e $\mathrm{Fe}$, essas mesmas análises revelaram que nas esmeraldas há um teor de $\mathrm{Cr}_{2} \mathrm{O}_{3}$ variando entre 0,08 e 1,34\%, havendo uma relação entre o aumento da cor e o aumento desse cromóforo. Por sua vez, o teor de $\mathrm{FeO}$ varia entre $1,23 \mathrm{e}$ 2,66\% em peso, não havendo correlação com o aumento da intensidade de cor.

Estudos ópticos, de difração de raios $\mathrm{X}$ e de microssonda eletrônica revelaram que a esmeralda de Santa Terezinha de Goiás contém uma grande variedade de inclusões cristalinas, destacando-se, por ordem de abundância, a cromita, os carbonatos (dolomita e magnetita), o talco, a flogopita, a pirita, a patronita, o quartzo, a barita, o berilo e a ferropargasita. A cromita aparece em duas gerações composicionais distintas, as quais apresentam 2,0 e $10,0 \%$ de $\mathrm{Al}_{2} \mathrm{O}_{3}$, respectivamente. Os carbonatos (dolomita e magnetita) exibem zoneamento químico com núcleos contendo aproximadamente 1,6\% de $\mathrm{FeO}$ e bordas com 8,5\% de FeO. As inclusões fluidas constituem uma feição notável dessa esmeralda, especialmente quando observadas sob aumentos maiores, podendo-se afirmar que estão presentes praticamente em todos os espécimes estudados. Essas inclusões possuem uma, duas ou três fases distintas, mostrando uma grande variedade de formas e uma certa variação nos conteúdos presentes nas cavidades.

Com base nos dados obtidos nos trabalhos de campo e de laboratório, foi possível compreender alguns dos inumeros problemas inerentes à gênese da jazida de Santa Terezinha de Goiás. Entretanto permanece ainda como uma questão controvertida a fonte do berílio nessa jazida, havendo possibilidade da mesma não ser pegmatítica, como na maioria dos depósitos brasileiros e estrangeiros. Tudo indica que ela pode estar relacionada a uma remobilização durante o metamorfismo de alto grau que afetou a região durante o Proterozóico Médio no Ciclo Uruaçuano. A referida fonte pode estar também ligada a soluções provenientes do Granito São José do Alegre, localizada a $5 \mathrm{~km}$ dos garimpos, ou ainda a derrames ácidos ligados à Seqüência Greenstone Belt de Crixás-Guarinos- Hidrolina-Pilar de Goiás. Os elementos cromóforos são derivados de rochas metaultramáficas do tipos talco xistos e biotititos existentes nos garimpos.

Com relação aos controles dos depósitos, dois fatores básicos controlaram a mineralização de esmeralda em Santa Terezinha de Goiás: um de caráter estrutural e o outro de caráter litológico. O controle estrutural é representado por dobras em monoclinais, sendo o controle litológico, por sua vez, representado por camadas de talco xistos e lentes de biotititos.

Os garimpos de Santa Terezinha de Goiás constituem a mais importante área de produção de esmeralda na atualidade, suplantando a produção das minas famosas de Muzo, Cosquez e Chivor, na Colômbia. Apesar das dificuldades de controle da produção, cálculos efetuados na boca da mina indicam que o montante de esmeralda garimpado representa um valor aproximado de 2 bilhões de dólares/ano.

Abstract: The emerald garimpos (prospects) of Santa Terezinha de Goiás are located in the west-central part of the Goiás State, about $23 \mathrm{~km}$ to the northeast of the Santa Terezinha Town.

The garimpos of this region constitute the most important active production area for emeralds in Brazil-current production surpasses that of the famous Colombian mines, and is estimated to be in the range of US\$ 2 billion per year.

Regionally, three distinct tectonic terranes can be distinguished: 1) a sequence of low metamorphic grade rocks, composed of chlorite-schist, talc-schist and biotite-schist, in which the emeralds occur; 2) a gneissic-amphibolite terrane (which lies to the southwest of the emerald-bearing schist) and 3) a granitic batholith which intrudes a sequences of gneissic rocks located northwest the emerald-bearing schist terrane.

The geological mapping of the area legal de garimpagem (legal zone where prospecting is 
allowed by a federal law), within the above region proved the existence of two lithologically distinct groups, represented by the gneissic-granite complex and by the Santa Terezinha sequence, composed by the lithologies referred to above.

Petrographical descriptions of rocks exposed in a 117 deep shaft, show that within the schist terrane emerald-mineralized rocks are, more specifically, quartz-carbonate-talc schists (1) and biotite/phlogopite schists, while the no emerald-bearing rocks are biotite/phlogopite-carbonate schists with a little quartz, the quartz-carbonate-talc schists (2), muscovite-chlorite-carbonate-quartz schists and blastomylonites. In the rocks belonging to the mineralized levels, tourmaline, beryl (emerald) and carbonates have anomalous biaxiality, when viewed in thin section, suggesting that the host rocks of emerald were subjected to tectonic deformation after emerald formation.

The emeralds of Santa Terezinha de Goiás are characterized by their intense green color, by refractive indices with the values $\mathrm{n}_{\delta}=1.580-1.597, \mathrm{n}_{\boldsymbol{\omega}}=1.586-1.599$, birefringence between 0.001 and 0.010 and by specific gravity which varies from 2.673 to 2.774 with average values of 2.711 . Scanning microprobe analyses in these emeralds have shown that, among the main oxides, the weight percent of $\mathrm{SiO}_{2}$ varies between 62.33 and $65.30 \%$, the $\mathrm{Al}_{2} \mathrm{O}_{3}$ between 12.05 and $13.13 \%$, the $\mathrm{MgO}$ between 2.48 and $2.77 \%$, and the $\mathrm{Na}_{2} \mathrm{O}$ between 1.31 and $2.91 \%$. The amount of $\mathrm{Cr}_{2} \mathrm{O}_{3}$ varies between 0.08 and $1.34 \%$ : an increase $\mathrm{Cr}_{2} \mathrm{O}_{3}$ corresponds to an increase in intensity of the green color of the emeralds. The weight percent of $\mathrm{FeO}$ varies from 1.23 to $2.66 \%$; there is no correlation between $\mathrm{FeO}$ concentration and color.

Optical, X-ray diffraction and scanning microprobe analyses have shown that the emeralds from Santa Terezinha de Goiás contains a large variety of crystalline inclusions such as chromite, carbonates (dolomite and magnesite), talc, phlogopite, pyrite, patronite, quartz, barite, beryl and ferropargasite. There are two compositionally distinct chromite generations, having 2.0 and $10.0 \%$ of $\mathrm{Al}_{2} \mathrm{O}_{3}$ respectively. The carbonates (dolomite and magnesite) display chemical zoning with cores containing approximately $1.6 \%$ $\mathrm{FeO}$ and edges with $8.5 \% \mathrm{FeO}$. Fluid inclusions are present in almost all samples studied. They have one, two or three distinct phases. Fluid inclusions have variety of shapes.

Based on the data obtained in field and lab work, it was possible to understand some of the various problems typical of the origin of the Santa Terezinha de Goiás deposit. However, the source of beryllium in this deposit is highly controversial. In contrast to the great majority of Brazilian and world emerald deposit, the emeralds of this region are not associated with a pegmatite beryllium source. The beryllium may have been added to the rock during high grade metamorphism which affected the region during the Mid Proterozoic in the Uruaçuano Period. Another source of beryllium may be solutions derived from the São José do Alegre Granite, located $5 \mathrm{~km}$ from the garimpos, and another possible source might be acid flows within to the greenstone belt sequence of Crixás-Guarinos-Hidrolina-Pilar de Goiás. The elements that cause the color of the emerald come from meta-ultramafic rocks as the talc-schists and biotitites present in the garimpos.

Two basic factors controlled the mineralization of emerald in Santa Terezinha de Goiás. The location of emerald is structurally controlled (they occur in hinge areas of monoclinic folds) and is lithologically controlled (they occur only in talc schists and in lenses of biotitite).

OLIVEIRA, Mirian Cruxên Barros de

Petrologia do Maciço Granítico Mandira, SP. 23 de maio. 181p. 1 vol. Orientador: José Vicente Valarelli. 
Resumo: O maciço Granítico Mandira constitui um corpo granítico peralcalino, de aproximadamente 50 $\mathrm{km}^{2}$ de área, nitidamente intrusivo, com forma alongada elipsoidal e eixo maior com direção N40E, localizado no sul do Estado de São Paulo, na região Administrativa do Vale do Ribeira.

Limita-se a N e NW com as rochas gnáissico-migmatíticas do Complexo Costeiro, as quais são transicionais (a oeste) para os granitos anatéticos ou sintectônicos da Fácies Cantareira. No extremo NE ocorrem os ectinitos do Complexo Turvo-Cajati.

Petrograficamente distinguem-se três unidades no Maciço: Acaraú $(\gamma \mathrm{A})$, que ocorre em dois stocks na porção meridional do pláton e é composta principalmente por mesopertita granito com ferrohastingsita; Mandira $(\gamma \mathrm{M})$, que compóe o corpo principal do maciço e apresenta composição de mesopertita granito com riebeckita; Mandira 1 ( $\gamma \mathrm{M} 1$ ), que ocorre em quatro stocks na periferia do corpo maior de $\gamma \mathrm{M}$ e é composta principalmente por granito $3 \mathrm{~A}$. Além das três unidades graníticas ocorrem regiões afetadas em graus variados por processos tardi- a pós-magmáticos: greisenização, albitização e feldspatização potássica, por vezes associados a intenso hidrotermalismo. As regiões afetadas pelos processos tardi- a pós-magmatismo encontram-se enriquecidas em $\mathrm{Zn}, \mathrm{Pb}$ e $\mathrm{Cu}$, que geralmente constituem as mineralizações.

Esta pesquisa apresenta a caracterização petrográfica, mineralógica e química do maciço, a partir de estudos em amostras de rocha (superfície e testemunhos de sondagem). Propõe também uma hipótese para a evolução petrogenética do Maciço Granítico Mandira, envolvendo a intrusão e colocação das várias unidades graníticas bem como o estudo dos processos de alteração tardi- a pós-magmáticos.

Abstract: The Mandira Massive is an alkalic granitic body covering an area of approximately $50 \mathrm{~km}^{2}$ in the Administrative Region of the "Vale do Ribeira" in the southern of the São Paulo State.

It shows clear intrusive relations, despite its mapped lensoid shape whose longest axis (N40E) parallels the regional main structural direction.

At N and NW the country rocks belong to the gneiss-migmatitic Complexo Costeiro, transitional (to the west) to syntectonic or anatectic granites of Cantareira facies. At the NE end ectinites of the Complexo Turvo-Cajati occur.

Three units are petrographically distinguished in the massive: 1) Acarau ( $\gamma \mathrm{A})$, exposed in two stocks at the meridional part of the pluton, made up essentially of ferrohastingsite bearing mesoperthite granite; 2) Mandira ( $\gamma \mathrm{M})$ that constitutes the main volume of granite present in the massive and is composed by riebeckite bearing mesoperthite granite; 3) Mandira 1 ( $\gamma$ M1), occurring in four stocks scattered along the massive border zone and showing a granite $3 \mathrm{~A}$ composition. In addition to the above cited units regions were detected which were variously affected by tardy to post magmatic process; greisenization, albitization and $\mathrm{K}$-feldspathization, sometimes associated to intensive hydrothermal action. Such regions prove to be enriched by $\mathrm{Zn}, \mathrm{Pb}$ and $\mathrm{Cu}$ mineralizations.

This research substantiates the present chemical, mineralogical and petrographical knowledge about the Mandira Massive and was carried out from studies on bore core and surface samples. It also presents a hypothesis aiming to explain the massive petrogenetic evolution comprehending intrusion and emplacement of the several granitic units as well as the tardy to post magmatic alteration which followed this process. 
Mineralogia e geologia da esmeralda da jazida de Itabira, Minas Gerais. 04 de abril. 192p. 1 vol. Orientador: Darcy Pedro Svisero.

Resumo: O mapeamento litologico da área da jazida de esmeralda de Itabira, Minas Gerais, cobrindo cerca de $60 \mathrm{~km}^{2} \mathrm{em}$ torno da mina, revelou a presença de dois conjuntos litoestruturais maiores constituídos respectivamente por rochas gnáissicas de composição granítica, pertencentes ao Complexo Basal, e por uma seqüência vulcano-sedimentar, possivelmente arqueana, profundamente intemperizada e parcialmente encaixada nos gnaisses.

Em termos petrograficos, as litologias gnaiissicas correspondem dominantemente, no triângulo Q-FA-P de STRECKEISEN (1967 e 1976), à composição grańftica (campos 3a e 3b) e aos granitóides ricos em quartzo, manifestando ainda uma tendência composicional para o campo dos álcali-granitos. A seqüência vulcano-sedimentar, por sua vez, compõe-se basicamente de xistos e gnaisses metapelíticos, anfibolitos diversos, xistos derivados de metaultramáficas e quartzitos. Subordinadamente, aparecem veios de quartzo e veios pegmatoides, preferencialmente junto aos contatos com as rochas gnaissicas.

A jazida de Itabira localiza-se praticamente no contato entre a seqüência vulcano-sedimentar e os gnaisses graniticos, em área de falhamentos, estando a mineralização esmeraldffera concentrada dominantemente nas intercalações de xistos provenientes de rochas metaultramáficas (biotititos). As assembleias minerais encontradas na área da jazida indicam que as litologias ali existentes foram submetidas a um metamorfismo regional progradante da fácies xisto-verde superior a anfibolito médio.

A esmeralda de Itabira caracteriza-se principalmente por apresentar boa cristalização, pleocroismo distinto $\left(\omega=\right.$ verde amarelado e $\epsilon=$ verde azulado), indices de refração com valores de $\mathbf{n}_{\epsilon}=$ $1,579-1,584, n_{\omega}=1,584-1,588, \Delta n=0,004-0,006$, densidade relativa média de 2,77 e poucas inclusões sólidas minerais. Determinaçöes dos parâmetros da cela unitária forneceram os seguintes valores: $a_{0}=9,220-$ $9,236 \pm 0,002 \mathrm{~A}, c_{0}=9,201-9,207 \pm 0,005 \mathrm{~A}$ e V $=677,5-679,8 \pm 0,3 \mathrm{~A}^{3}$. Estudos de difração de raios $X$ revelaram mica (biotita/flogopita), quartzo, ralstonita, magnesiocromita e b́xidos amorfos como as principais inclusões minerais. A mica $\in$ a inclusão cristalina mais freqüente nessa esmeralda, ocorrendo em placas euedricas singenéticas dispostas paralelamente ao pinacbide basal $\{0001\}$ da esmeralda, em placas subedricas ligeiramente arredondadas, de natureza protogenética, sem orientaçăo preferencial. Além disso, os estudos opticos revelaram um grande número de inclusões fluidas na forma de tubos diminutos orientados paralelamente ao eixo c da esmeralda e cavidades geométricas contendo, geralmente, preenchimentos trifásicos do tipo liquido-líquido-gás ou polifásicos do tipo cristal-líquido-líquido-gas. Fraturas cicatrizadas, zoneamentos de cor e linhas de crescimento foram também observadas.

Com base nos dados obtidos neste trabalho, a formação da esmeralda de Itabira está intimamente relacionada aos contatos falhados, entre os dois conjuntos litoestruturais. $O$ berilio proveio dos gnaisses graniticos pelo transporte dos fluidos pegmatificos e os elementos cromóforos são derivados das rochas metaultramáficas, localmente, metassomatizadas. O processo de formação da jazida parece estar compreendido entre as etapas pneumatolítica e hidrotermal, tendo em vista a natureza das concentraģöes pegmatoides e o grande número de inclusões fluidas na esmeralda.

Abstract: Geologic mapping of about $60 \mathrm{~km}^{2}$ in the area of the Itabira emerald deposit, Minas Gerais, revealed two main lithostructural units: one represented by gneissic rocks of granitic composition belonging to the Basement Complex, and the other, partly enclosed in the former, composed of a highly weathered metasedimentary-metavolcanic sequence, probably Archean in age.

According to the Q-A-F triangle of Streckeisen, the gneissic rocks exhibit compositions 
predominantly in the granitic ( $3 \mathrm{a}$ and $3 \mathrm{~b}$ ) fields and in the quartz-rich granitoid field. They exhibit, moreover, a compositional tendency to the alkali granite field. The metasedimentary-metavolcanic sequence is essentially composed of metapelitic schists and gneisses, some types of amphibolites, schists derived from ultramafic rocks, and quartzites. Subordinately, quartz and pegmatoid veins appear near the contacts with the gneissic rocks.

The Itabira emerald deposit is located along faults at the contact between the metasedimentarymetavolcanic sequence and the granitic gneisses. Emerald mineralization is dominantly concentrated within the intercalations of schists derived from meta-ultramafic rocks (biotitites). The mineral assemblages found in the deposit indicate a progressive regional metamorphism in the upper green-schist to middle amphibolite facies.

The main characteristics of emeralds from Itabira are distinct pleochroism $(\omega=$ yellowish green, and $\epsilon=$ bluish green); refractive indices of $n_{\epsilon}=1.579-1.584$ and $n_{\omega}=1.584-1.588$ with $\Delta n=0.004$ 0.006 ; specific gravity of $2.77 \mathrm{~g} / \mathrm{cm}^{3}$; and few mineral solid inclusions, as well as structural defects. Determinations of the unit-cell parameters furnished the following dimensions: $a_{o}=9.220-9.236 \pm 0.002 \mathrm{~A}$, $c_{o}=9.201-9.207 \pm 0.005 \mathrm{~A}$, and $\mathrm{V}=677.5-679.8 \pm 0.3 \mathrm{~A}^{3}$. X-ray diffraction studies revealed mica (biotitephlogopite), quartz, ralstonite, chromite and amorphous oxides as the main solid inclusions. Mica, the most common crystalline inclusion, may be syngenetic or protogenetic, the former as euhedral plates parallel to the $\{0001\}$ plane of the emerald, and the later as rounded subhedral plates randomly distributed in the host beryl. In addition, optical studies revealed a great amount of fluid inclusions occurring as minute acicular tubes parallel to the $\mathbf{c}$ axis of the emerald, and geometric cavities usually filled with three or more phases of inclusions such as liquid-liquid-gas and crystal-liquid-liquid-gas types. Healing fractures, color zoning and growth lines were also observed.

The origin of the emerald from Itabira is closely related to the faulted contacts between the gneissic and the metasedimentary-metavolcanic sequence. The beryllium was transported by pegmatitic fluids from adjacent granitic gneisses, and the chromophores were derived from ultramafic rocks which locally suffered metasomatism. The nature of the pegmatoid concentrations and the great amount of fluid inclusions in the emerald suggest that the deposit of Itabira originated through a hybrid process involving pneumatolytic and hydrothermal stages.

\section{SZABÓ, Gergely Andrés Júlio}

Contexto geologico e petrologia das rochas metaultramáficas de Alpinópolis, MG. 19 de dezembro. 203p. 1 vol. Orientador: Rainer Alloys Schultz-Güttler.

Resumo: As rochas metaultramáficas que ocorrem a sul e sudoeste da cidade de Alpinópolis, no sudoeste de Minas Gerais, constituem corpos de tamanho variado, embutidos em terrenos ortognáissicos/ graníticos. Destes corpos, dois se destacam pelo porte: o maior, de Casca D' Anta, a sul de Alpinópolis, com cerca de $5 \mathrm{~km}^{2}$ de superfície exposta, e o da Fazenda Gordura, a oeste, com aproximadamente $2 \mathrm{~km}^{2}$ de área estimada. Corpos menores, de algumas centenas de $\mathrm{m}^{2}$, se distribuem como satélites ao redor de corpo maior; algo mais afastado, ocorrem lentes e bandas ultramáficas centi- a decimétricas dispersas, inclusas nos ortognaisses. Nos corpos maiores, as rochas metaultramáficas são acompanhadas, em proporção subordinada, por anfibolitos diversos, granada micaxistos (às vezes com estaurolita), formações ferríferas bandadas (BIF) e metacherts. 
O conjunto dos terrenos ortognáissicos/graníticos e dos corpos ultramáficos intercalados é interpretado como um domínio tipo granito-greenstone intensamente modificado, no Proterozóico Médio ou Inferior por episódios tectono-termais sucessivos, e representaria o componente mais antigo, do Arqueano ou Proterozóico Inferior, do Complexo Campos Gerais. A norte, este domínio é discordantemente recoberto pela seqüência metassedimentar psamo-pelítica alóctone do Grupo Araxá-Canastra, do Proterozóico Médio, através de uma extensa superfície de cisalhamento de baixo ângulo.

Nos terrenos ortognáissicos/graníticos predominam termos tonalíticos/granodioríticos; biotita ortognaisses tonalíticos, cinza e porfiróides (tipo Serra do Dond6) constituem núcleos melhor preservados em meio à suíte de ortognaisses granodioríticos, laminados/bandados, protomiloníticos a miloníticos e parcialmente remobilizados, dos quais seriam os antecessores. Outros tipos petrográficos presentes nestes terrenos seriam os ortognaisses tonalíticos cinza-esverdeados, não porfiróides, homogêneos (tipo Fazenda das Almas), granitoides e gnaisses graníticos vários, migmatitos e corpos de granitóides hololeucocráticos pegmatóides a micrograníticos de dimensões reduzidas e colocação tardi/pós-tectônica. A estruturação destes terrenos é fortemente linear, marcada por uma intensa foliação de cisalhamento de alto ângulo, de direção WNW/ESE; a feição megaestrutural mais conspícua, representada por um forte alinhamento de relevo de traçado sinuoso, definido pelas encostas sul, mais íngremes, das Serras do Quilombo e do Dond6, seria uma falha transcorrente sinistral que parasita as direções estruturais mais antigas, estabelecidas no decorrer do cisalhamento dúctil de alto ângulo.

Nos corpos ultramáficos predominam amplamente variedades de clorita-tremolita xistos e fels, com a assembléia mineralógica fundamental constituída de anfibólio tremolítico e clorita magnesiana, tipo pennina/clinocloro, em proporções variáveis, além de ilmenita e magnetita por acessórios onipresentes, e anfibólio antofilítico, olivina (freqüentemente serpentinizada), ortopiroxênio (às vezes talcificado) e espinélio por acessórios ocasionais mais característicos. Os outros litotipos ultramáficos, presentes em proporção mais modesta, são clorita serpentinitos (com amplo predomínio de serpentina tipo antigorita, e às vezes com pseudomorfos de texturas granulosas: ortocumuláticas?) e serpentina xistos, metapiroxenitos, talco-xistos e serpentina-talco xistos carbonáticos. A presença de ocasionais texturas spinifex reliquiares nos clorita-tremolita xistos e fels e de formações ferríferas bandadas e metacherts associados sugerem que estas rochas sejam metakomatiítos, e os corpos ultramáficos restos desmembrados de uma seqüência vulcanosedimentar tipo greenstone belt com predomínio de termos komatíticos. Anfibolitos grano-nematoblásticos finos, concordantemente intercalados às rochas metaultramáficas, cor responderiam a metavulcânicas básicas, enquanto anfibolitos blastoporfiróides, em corpos alongados discordantes da foliação principal, seriam diques de colocação posterior, presentes também nos terrenos ortognáissicos ao redor.

A estruturação interna dos corpos ultramáficos, parcialmente discordante da forte estruturação linear dos terrenos ortognáissicos, é marcada por uma foliação de cisalhamento sinuosa, anastomosada, que envolve núcleos lenticulares de rocha maciça ou menos intensamente foliada, portadores das texturas ígneas reliquiares e dobrada segundo um padrão sanfonado que, em escala mesoscópica, se manifesta através de dobras em chevron. São praticamente inexistentes evidências do empilhamento original do pacote vulcanosedimentar, e não foram encontrados vestígios do embasamento sobre o qual teria originalmente se depositado. Os contatos com as rochas ortognáissicas ao redor, são predominantemente tectônicos, com desenvolvimento de foliação milonítica de ambos os lados, e exibem freqüentemente um aspecto alternado/intercalado, condicionado pela infiltração de material granítico ao longo dos planos de cisalhamento. Contatos intrusivos verificam-se apenas com os corpos pegmatóides e micrograníticos, tardi/pos-deformacionais.

Treze amostras de variedades de clorita-tremolita xistos e fels, a maioria com textura spinifex 
reliquiar, foram selecionadas para análise química. Os resultados indicam que, apesar das modificações sofridas no seu quimismo, há vestígios de um padrão geoquímico supostamente original da suíte komatíitica, que seria comparável ao padrão de komatítos empobrecidos em alumínio, tipo ADK (aluminium depleted komatiites - NESBITT et al., 1979), similar ao de Barberton, África do Sul, e Pilbara, Austrália Ocidental. Duas amostras de anfibolitos tidos como derivados de metavulcânicas básicas intercaladas às rochas ultramáficas forneceram composições toleíticas magnesianas.

O metamorfismo das rochas ultramáficas desenvolveu-se de maneira policíclica, sob condições que variaram significativamente no tempo e no espaço, acompanhando um regime de deformações heterogêneo e recorrente. A evolução metamórfica encontra-se mais claramente registrada nas variedades de clorita-tremolita xistos e fels: as transformações, que acompanham o metamorfismo progressivo nestas rochas são melhor modeladas, tentativamente, através da variação composicional da clorita magnesiana, que enriquece em alumínio, com o incremento do grau metamórfico e da reação de quebra da clorita final saturada em alumínio: Mg-clorita forsterita + enstatita + espinélio + $\mathrm{H}_{2} \mathrm{O}$ (JENKINS \& CHERNOSKY, 1986). Nos clorita-tremolita xistos com nódoas serpentiníticas e com textura spinifex reliquiar do interior do corpo ultramáfico maior, microporfiroblastos de anfibólio antofilítico e porfiroblastos serpentinizados de olivina, estes últimos mimetizando inclusive o traçado da textura spinifex reliquiar, ocorrem nitidamente associados aos domínios com clorita e seriam originados pelo componente magnesiano em excesso liberado pela clorita quando do seu enriquecimento em alumínio. A reação de quebra da clorita estaria registrada nos (clorita-) tremolita fels com nódoas pluriminerálicas de olivina+ortopiroxênio e com espinélio dos corpos menores que circundam o corpo ultramáfico maior. As condições metamórficas de pico teriam sido de fácies anfibolito médio a superior (temperaturas máximas estimadas em torno de $650-700^{\circ} \mathrm{C}$ considerando pressões da ordem de 3-5 kb). Transformações retrometamórficas mais em evidência são a exsolução de um componente cummingtonítico nos anfibólios tremolíticos a reconstituição parcial da clorita e o desenvolvimento de anfibólio antofilítico sobre o ortopiroxênio nas rochas com olivina, ortopiroxênio e espinélio; a recristalização de anfibólio tremolítico e clorita nas zonas de charneira das dobras em chevron, e a serpentinização da olivina e talcificação do ortopiroxênio e do anfibólio antofilítico. Talcificação é um fenômeno freqüente, ao longo das superfícies de cisalhamento internas, enquanto serpentinização acompanha a milonitização de borda dos corpos ultramáficos, dando origem aos serpentina xistos manchados, com aspecto de pele de cobra.

Abstract: The meta-ultramafic rocks which occur to the south and southwest of Alpinopolis town, in southwestern Minas Gerais State, Brazil, build up bodies of variable size inlaid in orthogneissic/granitic terrains. Two of these bodies stand out by their size: the largest, of Casca D'Anta, to the south of Alpinópolis, with about $5 \mathrm{~km}^{2}$ of exposed surface, and the other one, of Fazenda Gordura, to the west, with an estimated surface of approximately $2 \mathrm{~km}^{2}$. Smaller bodies of some hundreds of $\mathrm{m}^{2}$ are distributed as satellites around the largest body; somewhat further off, centimetric to decimetric ultramafic lenses and bands occur scattered, included in the orthogneisses. In the larger bodies, the ultramafic rocks are followed, in lesser quantities, by various types of amphibolites, garnet mica schists (sometimes with staurolite), banded iron formations (BIF) and metacherts.

The orthogneissic/granitic ensemble with the inlaid ultramafic bodies is considered to be a granite-greenstone type domain intensively modified during the Lower to Middle Proterozoic by successive tectono-thermal events, and would thus represent the oldest component, of Archean or Lower Proterozoic age, of the Campos Gerais Complex. To the north, this domain is discordantly overlain by the allochthonous, psammo-pelitic metasedimentary sequence of the Araxá-Canastra Group, of Middle 
Proterozoic age, through a low-angle shear surface.

In the orthogneissic/granitic terrains tonalitic/granodioritic components predominate; grey, porphyroid tonalitic biotite orthogneisses (Serra do Dondo type) occur as better preserved nuclei in a suite of laminated/banded, protomylonitic to mylonitic, partially remobilized granodioritic gneisses, of which they would be the foregoers. Other rock types that occur in these terrains are grey-green, non-porphyroid, homogeneous-looking tonalitic orthogneisses (Fazenda das Almas type), various kinds of granitoids and granitic gneisses, migmatites, and lesser bodies of hololeucocratic, pegmatoid to aplitic granites of tardi- to posttectonic emplacement. The structural framework of these terrains is strongly linear, characterized by a high-angle shear foliation of WNW/ESE direction; the most prominent megastructural feature, a strong, sinuous alignment defined by the steeper, southern slopes of the Serra do Quilombo and Serra do Dondo, would be a sinistral transcurrent fault which follows the older structural directions established during the high-angle heterogeneous ductile shearing.

In the ultramafic bodies, varieties of chlorite-tremolite schists and fels predominate by large, with a fundamental mineralogical assembly made up by a tremolitic amphibole and a magnesiochlorite, of pennine/clinochlore type, in variable proportions, with magnetite and ilmenite as ubiquitous accessories. Anthophyllitic amphibole, olivine, orthopyroxene and spinel, as well as serpentine and talc can eventually occur as accessories or lesser constituents. The other ultramafic rocks, which occur in more discreet proportions, are chlorite, serpentinites (with antigorite as main serpentine variety, and with remnants of a granulose/orthocumulatic (?) pseudomorphic texture) and serpentine schists, metapyroxenites, talc schists and carbonatic serpentine-talc schists. The presence of occasional relict spinifex textures in the chloritetremolite fels and schists and the occurrence of intercalated banded iron formations suggest that these rocks are metakomatiites, and the ultramafic bodies the remnants of a dismembered greenstone belt type volcanosedimentary sequence in which komatiitic components predominate. Fine-grained, grano-nematoblastic amphibolites concordantly intercalated with the ultramafic rocks would correspond to lesser metavolcanics, whilst elongated bodies of blastoporphyroid amphibolites discordant to the main foliation in the ultramafic bodies would be basic dykes of later emplacement, to be found also in the orthogneissic terrains.

The internal structural framework of the ultramafic bodies, partly discordant from the strong linear structural framework of the orthogneissic terrains around, is defined by a sinuous and anastomosed shear foliation which envelopes lenticular nuclei of massive or less foliated rocks with relict igneous textures, folded in an accordion-like pattern that produces chevron-type folds on a mesoscopic scale. There is very little or practically no evidence concerning the original piling-up of the volcano-sedimentary sequence, and no signs whatsoever of the basement over which this sequence would have been originally laid down were found. The contacts with the orthogneissic rocks around are predominantly tectonic, with mylonitic foliation developed on both sides, and frequently exhibit an alternated/intercalated aspect due to the infiltration of granitic material along the shear planes.

Thirteen samples of chlorite-tremolite schist and fels varieties, most of them with relict spinifex textures, were selected for chemical analysis. The results show that, although there were changes in their chemistry, they preserve evidences of an original geochemical pattern for the komatiitic suite, which would be comparable to that of ADK - aluminium depleted komatiites (NESBITT et al., 1979) like those of Barberton, South Africa, and Pilbara, Western Australia. Two amphibolite samples considered to be basic metavolcanics intercalated to the ultramafic rocks furnished magnesian tholeiitic compositions.

The metamorphism of the ultramafic rocks developed in a polycyclic manner, under conditions which varied significantly in time and space, accompanied by a heterogeneous and recurrent deformational regime. Their metamorphic evolution is more clearly recorded in the chlorite-tremolite schist and fels 
varieties: the changes due to progressive metamorphism in these rocks are better understood, tentatively, through the aluminium content increase of the magnesiochlorite following the metamorphic grade rises, and through the breaking-down of the final, aluminium- saturated chlorite according to the reaction: $\mathbf{M g}$ chlorite $=$ forsterite + enstatite + spinel $+\mathrm{H}_{2} \mathrm{O}$ (JENKINS \& CHERNOSKY, 1986). In the chloritetremolite schists and fels with serpentinite spots and reliquiar spinifex textures found in the inner portions of the largest ultramafic body, anthophyllitic amphibole microporphyroblasts, and serpentinized olivine prophyroblasts, these last ones neatly mimetizing the contours of the relict spinifex textures, are clearly related to the chloritic domains, and are considered to be brought about by the excess magnesian component released by the chlorite during its aluminium enrichment. The breaking-down of chlorite saturated in aluminium would be recorded in the (chlorite-) tremolite fels with olivine/orthopyroxene bearing plurimineralic spots and green spinel, which occur in the smaller ultramafic bodies enclosed in the orthogneissic tocks around the largest one. Peak metamorphic conditions would have been of middle to upper amphibolite facies (maximum temperatures estimated around $650-700^{\circ} \mathrm{C}$ for pressures about $3-5 \mathrm{~kb}$ ). The commonest retrometamorphic features to be found would be the exsolution of a cummingtonitic component in the tremolitic amphiboles, the partial recomposition of chlorite and the development of a new anthophyllitic amphibole over orthopyroxene in the rocks with olivine, orthopyroxene and spinel, the recrystallization of tremolitic amphibole and chlorite in the hinge-zones of the chevron folds, and the serpentinization of olivine and talcification of orthopyroxene and anthophyllitic amphibole. Talcification occurs commonly along the internal shear surfaces, whilst serpentinization characterizes the border mylonites, giving rise to the spotted, snake-skin - like serpentinites.

VIEIRA, Silvia Regina Soares Silva

Estudo litoestrutural da região de Embú-Guaçu Parelheiros, São Paulo. 17 de agosto. 122p. 1 vol. Orientador: José Moacyr Vianna Coutinho.

Resumo: A área estudada abrange a porção sul da Grande São Paulo e arredores do município de EmbuGuaçu, correspondendo a um polígono de aproximadamente $480 \mathrm{~km}^{2}$ inscrito nas folhas topográficas, em 1:50.000, de Embu-Guaçu a Riacho Grande.

Foram aí caracterizadas duas unidades pré-cambrianas intrudidas pelos granitos de EmbuGuaçu, Parelheiros e Colônia aqui redefinido, e parcialmente recobertas por sedimentos terciários correlatos aos da Bacia de São Paulo e aluviões quaternários.

As seqüências pré-çambrianas, atribuídas ao Complexo Pilar do Grupo Açungui, estão representadas um conjunto, informalmente denominado Santa Rita, composto por micaxistos e quartzo xistos alternados ritmicamente e intercalados por veios pegmatíticos, rochas calciossilicáticas, metaultramáficas e anfibolíticas, e por uma unidade de sericita xistos e filitos mais homogêneos.

Sobre o acamamento sedimentar preservado tanto na unidade dos xistos rítmicos, quanto nos sericita xistos e filitos, acham-se expressos sob a forma de dobras e foliações pelo menos três eventos de deformação dúctil $\left(D_{1}, D_{2}, D_{3}\right)$ e um evento rúptil $\left(D_{4}\right)$ materializado através de texturas miloníticas e cataclásticas.

Contemporaneamente a $\mathrm{D}_{1}$ e em condições pré-cinemáticas a $\mathrm{D}_{2}$ houve a atuação de um episódio de metamorfismo regional $\mathbf{M}_{1}$ que atingiu seu ápice a pressóes maiores que $5 \mathbf{k b}$ e temperatura entre $575^{\circ} \mathrm{C}$ e $700^{\circ} \mathrm{C}$, compatíveis com as esperadas para ofácies anfibolito. 
Associadas à colocação dos corpos graníticos processaram-se transformações metassomáticas de caráter regional e que resultaram na cristalização de muscovita, fibrolita e turmalina sincinemáticas a tardias a $\mathrm{D}_{3}$. É provável, ainda, que este evento tenha sido responsável pela granitização do corpo de Colônia através da introdução de uma solução ácida, rica em potássio sobre um substrato básico.

$\mathrm{O}$ resfriamento que se seguiu a este período promoveu a adaptação das assembléias minerais produzidas em $\mathbf{M}_{1}$ a novas condições, caracterizando em episódio $\mathrm{M}_{3}$, de metamorfismo retrógrado.

Finalmente, relacionado à movimentação nas zonas de falha há um evento $\mathbf{M}_{\mathbf{4}}$ de metamorfismo cataclástico, restrito.

Datações efetuadas através de método K/Ar sobre o Granito de Embu-Guaçu e sobre um pegmatito a ele associado apontaram valores de $612 \mathrm{Ma}$. e $550 \mathrm{Ma}$. interpretados como as idades de formação destas rochas.

Para os xistos rítmicos, determinações realizadas a partir do método $\mathrm{Rb} / \mathrm{Sr}$ definiram uma isócrona com idade de $750 \mathrm{Ma}$. e razão inicial igual a 0,7277士0,0009.

Abstract: The area considered by this study comprehends a polygon of approximately $480 \mathrm{~km}^{2}$ in the Embu-Guaçu and Riacho Grande 1:50,000 topographic sheets, in the southern portion of the Grande São Paulo and roundabouts of Embu-Guaçu municipality.

Two Precambrian units, intruded by the Embu-Guaçu, Parelheiros and Colônia Granites (this last on redefined here) and partially covered by Tertiary sediments correlated to those of the São Paulo Basin and Quaternary alluvions were characterized in this area.

These Precambrian sequences ascribable to the Pilar Complex of the Açungui Group are represented by a suit informally called Santa Rica, made up of rhythmically alternated mica schists and quartz schists with intercalated pegmatitic veins and silicatic meta-ultramafic and amphibolitic rocks, and a more homogeneous set of sericite schists and phyllites.

At least three ductile deformational events $\left(D_{1}, D_{2}, D_{3}\right)$ are printed over the reliquiar sedimentary bedding both in the rhythmic schists and in the sericite schists and phyllites through folds and foliations, as well as a fourth ruptile one $\left(\mathrm{D}_{4}\right)$ through mylonitic and cataclastic textures.

An episode of regional metamorphism $\mathbf{M}_{1}$, which attained its peak at pressures over $5 \mathrm{kbar}$ and temperatures between $575^{\circ} \mathrm{C}$ and $700^{\circ} \mathrm{C}$, compatible with amphibolite facies conditions, developed contemporaneously to $\mathrm{D}_{1}$ and in conditions prekinematic to $\mathrm{D}_{2}$.

The crystallization of muscovite, fibrolite and tourmaline, synkinematic to late with regard to $\mathrm{D}_{3}$, was due to metasomatic transformations on a regional scale while followed the emplacement of the granitic bodies. It is possible that this event was also responsible for the granitization of the Colônia body through the introduction of a potash-rich acid solution in a basic substratum.

The cooling which followed this period promoted the adjustment of the mineralogical assemblies produced during $\mathbf{M}_{1}$ to the new conditions, thus defining the $\mathbf{M}_{3}$ retrometamorphic episode.

At last, there is a restricted $\mathrm{M}_{4}$ event of cataclastic metamorphism, related to the movements along the fault zones.

Values of $612 \mathrm{Ma}$ and $550 \mathrm{Ma}$ were obtained in age determinations by the $\mathrm{K} / \mathrm{Ar}$ method for the Embu-Guaçu Granite and a pegmatite associated to it, and are considered to represent the age of formation of these rocks.

For the rhythmic schists, age determinations by the $\mathrm{Rb} / \mathrm{Sr}$ method furnished a $750 \mathrm{Ma}$ isochrone with a $0,7277 \pm 0,0009$ initial ratio. 
Aspectos geoquímicos do impacto ambiental da mineração na Amazônia. Serra dos Carajás, Pará. 21 de dezembro. 144p. 1 vol. Orientador: Franco Levi.

Resumo: A Serra dos Carajás compreende parte do Cráton Brasil Central e da Amazônia, onde ocorrem depósitos de vários minérios, cuja importância, para o desenvolvimento do país é importante.

E exploração destes recursos minerais implica em modificações ambientais que podem comprometer o equilíbrio dinâmico dos ecossistemas na área. Assim, ao lado de outros projetos de pesquisa, que objetivam conhecer as características dos ecossistemas na área, se desenvolveu este trabalho cujo objetivo é conhecer a componente hídrica e o solo, sob as condições climáticas atuantes. Com estas informações e um monitoramento eficiente é possível controlar os impactos que podem se desencadear, em conseqüência da lixiviação dos efluentes da mineração dispostos no ambiente.

Uma vez introduzidas as modificações físico-químicas no substrato abiótico, todo o ecossistema sofre perturbações e tende a um desequilíbrio, decorrente das mudanças de teores anômalos que passam a interagir nos processos de biogeocenose.

Abstract: Serra dos Carajás is part of Brazil Central Craton in Amazonian Region where there are various mineral deposits which exploitation can contributes to the socioeconomic development of Brazil.

As result of the exploitation modification occur that can disturb the dynamic equilibrium of ecosystem. Thus, this study objectives the evaluation of the parameters that can characterize, in suui generis amazonian ecosystem, the hydric component and the soil like substratum of vegetation, under humid tropical conditions. This characterization of water and soil permit through efficient monitoring the control of impact, caused for lixiviation on disposed minings effluents.

Physic-Chemical modifications introduced into the abiotic substrate can change the ecosystem through disturbance that tends to complete disequilibrium in bigeicenose processes.

ZAMPIERI, Valdir Aparecido

Mineralogia e mecanismos de ativação e reação das pozolanas de argila calcinadas. 19 de abril. 191p. 1 vol. Orientador: Yushiro Kihara.

Resumo: A incorporação de materiais pozolânicos ao cimento portland vem assumindo importância crescente na atualidade, permitindo uma redução no seu consumo energético de fabricação e a obtenção de produtos com características tecnológicas diferenciadas, superiores em alguns aspectos aos próprios cimentos não aditivados. A distribuição restrita das cinzas volantes e das pozolanas naturais, aliada à vasta ocorrência de jazimentos argilosos, faz da ativação térmica de argilas uma das opções mais interessantes para a obtenção de pozolanas em nosso país.

O presente estudo procura sintetizar parte dos conhecimentos desenvolvidos no campo das pozolanas de argilas calcinadas, bem como contribuir para um melhor conhecimento dos mecanismos de ativação e reação desses materiais.

Para este propósito, realizaram-se estudos experimentais visando acompanhar as modificações mineralógicas que ocorrem em diferentes argilominerais, quando submetidos a aquecimento controlado, 
com posterior caracterização dos materiais calcinados quanto à atividade pozolânica. Atenção especial é dedicada ao reconhecimento e à análise das fases geradas a partir da reação pozolânica envolvendo argilas calcinadas e hidróxido de cálcio e, adicionalmente, ao estudo dos fatores que controlam a qualidade e reatividade dessas pozolanas.

A ativação térmica promove a perda da água de cristalização dos argilominerais e a formação de um material atomicamente desarranjado, com alto grau de desordem cristalina. $O$ desenvolvimento das propriedades pozolânicas dos materiais argilosos $e$ função, principalmente, da natureza e conteudo do argilomineral presente, das condições de calcinação e da finura do produto. A atividade pozolânica desses materiais está também limitada pelo conteúdo de fases inertes que ocorrem associadas, como por exemplo o quartzo.

As reações pozolânicas envolvendo argilas ativadas termicamente e o hidróxido de cálcio são, em essência, reações de dissolução e formação de novas fases. No meio fortemente alcalino, característico das misturas,contendo hidróxido de cálcio, os argilominerais ativados termicamente encontram-se em forte desequilibrio físico-químico, proporcionando, a nível de superfície das partículas, a dissolução do alumínio e do silício. Numa etapa posterior, e em função da grande disponibilidade de cálcio desse meio, observa-se a formação de aluminatos (carbo-aluminato e $\mathrm{C}_{4} \mathrm{AH}_{13}$ ), silicatos (gel de $\mathrm{C}-\mathrm{S}-\mathrm{H}$ ) e alumino-silicatos de cálcio hidratados $\left(\mathrm{C}_{2} \mathrm{ASH}_{8}\right.$ - gehlenita hidratada). Sob condições de cura acelerada $\left(55^{\circ} \mathrm{C}\right)$ pode-se reconhecer a presença de outro aluminato cálcico hidratado $\left(\mathrm{C}_{3} \mathrm{AH}_{6}\right)$.

A proporção e a seqũência de formação dessas fases dependem da reatividade e do quimismo da pozolana, do tempo de reação e da proporção pozolana/cal adotada. Com o prosseguimento da reação, os produtos que inicialmente ocorrem como uma película sobre as partículas argilosas começam a se desenvolver também nos espaços vazios da amostra, possibilitando um ganho crescente de resistência mecânica. O C-S-H e a gehlenita hidratada aparecem como os principais responsáveis pelo aumento de resistência mecânica das misturas de argila calcinada e hidróxido de cálcio.

Os estudos desenvolvidos permitem concluir, também, que as argilas cauliníticas mal cristalizadas são aquelas mais propícias à fabricação de pozolana. A reatividade dos argilominerais cauliníticos está intimamente relacionada com a geração de metacaulinita.

As argilas esmectíticas evidenciam um ganho pouco acentuado de reatividade quando ativadas termicamente. A baixa reatividade dos argilominerais esmectíticos dioctaédricos decorre, aparentemente, da manutenção parcial de suas estruturas, mesmo quando esses materiais são calcinados a temperaturas relativamente elevadas. $\mathrm{O}$ aspecto expansivo na hidratação e a tonalidade avermelhada do material, apos calcinação, constituem igualmente aspectos indesejáveis do ponto de vista tecnológico.

As argilas aluminosas, constituídas de misturas de argilominerais cauliníticos e gibsita, mostram-se bastante adequadas ao processo de ativação térmica, possibilitando a obtenção de um material com atividade pozolânica considerável. $\mathrm{O}$ maior conterbdo de $\mathrm{Al}_{2} \mathrm{O}_{3}$ dessas argilas confere-lhes entretanto uma maior refratariedade, deslocando o seu ótimo de reatividade para temperaturas mais elevadas.

As gibsitas puras revelam-se totalmente inadequadas para fabricação de pozolanas, tendo em vista as significativas expansões e as baixas resistências mecânicas observadas. Tal fato evidencia, por outro lado, que o teor de $\mathrm{SiO}_{2}$ reativo é de grande importância para o desempenho mecânico das pozolanas.

Finalizando, vale ressaltar que além de propiciarem uma visão mais detalhada dos mecanismos de ativação e reação das pozolanas de argilas, os resultados obtidos nesta pesquisa permitem uma seleção mais criteriosa dos materiais argilosos empregados para essa finalidade e, também, uma otimização de suas reatividades. 
Abstract: The addition of pozzolanic materials to portland cement is becoming increasingly important nowadays, permitting a reduction in its manufacturing energy consumption, and the production of cements with differentiated technological characteristics, in many aspects of better quality than those without additions. In Brazil, the limited distribution of fly ashes and natural pozzolans and the widespread occurrence of clay deposits make the thermal activation of clays one of the most interesting choices to obtain high quality pozzolans.

This study, apart from being a review of the state of the art, presents contributions for the better understanding of activation and reaction mechanisms in burnt clay pozzolans.

Experiments were carried out to follow up the mineralogical changes in different clay minerals, under controlled heating, with characterization of the obtained calcined materials with regard to their pozzolanic activity. Special attention was given to the recognition and analysis of phases produced by reactions involving calcined clays and calcium hydroxide and, additionally, to the understanding of factors that control the quality and reactivity of these pozzolans.

The thermal activation leads to loss of clay minerals structural water and the formation of highly disordered material. The development of pozzolanic properties in clays depends chiefly on the nature and abundance of the clay mineral used, on the calcination conditions, and on the fineness of the product. The pozzolanic activity of these materials is limited also by the content of associated inert phases, such as quartz.

Pozzolanic reactions between thermally activated clays and calcium hydroxide are essentially reactions of dissolution and formation of new stable phases. In strongly alkaline mixtures, which contain calcium hydroxide, thermally activated clay minerals are under severe disequilibrium, with ensuing dissolution of aluminium and silicium on the particle surfaces. In a further stage, calcium abundance leads to development of aluminates (carboaluminate and $\mathrm{C}_{4} \mathrm{AH}_{13}$ ), silicates $(\mathrm{C}-\mathrm{S}-\mathrm{H}$ gel) and hydrated calcium aluminosilicates $\left(\mathrm{C}_{2} \mathrm{ASH}_{8}\right.$ - hydrated gehlenite). Another calcic aluminate $\left(\mathrm{C}_{3} \mathrm{AH}_{6}\right)$ may crystallize under accelerated cure conditions (at $55^{\circ} \mathrm{C}$ ).

The formation sequence and ratio of these phases depend on pozzolan reactivity and chemistry, on reaction time and on the adopted pozzolan/lime ratio. As the reaction proceeds, the products, initially occurring as films over clayish particles, start to develop also in the voids of the sample, increasing the mechanical strength of the mixtures. The C-S-H and hydrated gehlenite are the main phases responsible for the mechanical strength of the pozzolan and calcium hydroxide mixtures.

It is also shown that poorly crystallized kaolinitic clays are the most suitable material for pozzolan production. The reactivity of kaolinitic clays is related to the generation of metakaolinite.

Thermally activated smectitic clays shows only a slight reactivity gain. The low reactivity of dioctahedral smectitic clays seems to be related to the partial maintenance of their structure, even when calcined at relatively high temperatures. Its expansiveness, observed during hydration reactions, and the reddish tones of the material after calcination are also technological draw backs.

Aluminous clays, made up of mixtures of kaolinitic clay minerals and gibbsite, are quite suitable for thermal activation, allowing the production of a material with considerable pozzolanic activity. Their great $\mathrm{Al}_{2} \mathrm{O}_{3}$ content, however, gives them a higher refractoriness, so that the heating has to be pushed into higher temperatures.

Pure gibbsites are completely inadequate for pozzolan production, on account of their significant expansiveness and low mechanical strength after calcination. These facts also show that the reactive $\mathrm{SiO}_{2}$ content is very important for the mechanical performance of the pozzolans.

Besides permitting a more detailed view of activation and reaction mechanisms of clay pozzolans, the results obtained by this research permit a better selection of the clays to be used as starting materials and also an improvement in their pozzolanic activities. 